\begin{abstract}
UNIVERSIDADE DE SÃO PAULO
FACULDADE DE FILOSOFIA, LETRAS E CIÊNCIAS HUMANAS DEPARTAMENTO DE LETRAS MODERNAS

PROGRAMA DE PÓS-GRADUAÇÃO EM LÍNGUA E LITERATURA FRANCESA
\end{abstract}

ALINE DA SILVA LIMA-VILLI

Mito, história e narrativa em Le Roi des Aulnes, de Michel Tournier 


\author{
UNIVERSIDADE DE SÃO PAULO \\ FACULDADE DE FILOSOFIA, LETRAS E CIÊNCIAS HUMANAS \\ DEPARTAMENTO DE LETRAS MODERNAS \\ PROGRAMA DE PÓS-GRADUAÇÃO EM LÍNGUA E LITERATURA FRANCESA
}

\title{
Mito, história e narrativa em Le Roi des Aulnes, de Michel Tournier
}

Aline da Silva Lima-Villi

Dissertação apresentada ao Programa de Pós-graduação em Língua e Literatura

Francesa do Departamento de Letras Modernas da Faculdade de Filosofia, Letras e Ciências Humanas da Universidade de São Paulo para obtenção de título de Mestre em Letras.

Orientador: Prof $\stackrel{\text { a }}{\text {. Dra }}$. Maria Cecilia Queiroz de Moraes Pinto

São Paulo

2010 
Com meus irmãos, Filipe e Daniele, compartilhei, na infância, a descoberta e a paixão por histórias sobre deuses, semideuses, monstros e humanos fascinantes.

A eles, pois, eu dedico este trabalho. 


\section{Agradecimentos}

À Prof ${ }^{a}$. Dr ${ }^{\mathrm{a}}$. Maria Cecilia Queiroz de Moraes Pinto, por quem tenho profunda admiração, eu agradeço pela orientação nos últimos sete anos, pela confiança que depositou na minha pesquisa desde o princípio e por tudo o que aprendi com ela, seja como intelectual, como pesquisadora, como professora.

Ao Prof. Dr. Gilberto Pinheiro Passos agradeço pelas preciosas sugestões e observações na ocasião da qualificação desta pesquisa.

Ao Prof. Dr. Jaime Ginzburg agradeço pela leitura cuidadosa, pelo incentivo e pela generosidade nas observações e sugestões.

À minha família, em especial ao meu marido, eu agradeço pelo encorajamento e apoio incondicional, pelas horas de dedicação e acolhimento. 
Se o mito é a linguagem primordial da experiência, os escritores modernos que exploram os recessos da consciência mítica e depositam os seus achados em obras de ficção deveriam ser estimados por manter-nos vitalmente em contato com as próprias fontes de nossa humanidade.

K. K. Ruthven 


\section{RESUMO}

LIMA-VILLI, A. S. Mito, história e narrativa em Le Roi des Aulnes, de Michel Tournier. 2010. 183 f. Dissertação (Mestrado) - Faculdade de Filosofia, Letras e Ciências Humanas, Universidade de São Paulo, São Paulo, 2010.

A reelaboração de mitos caracteriza, fundamentalmente, a obra do francês Michel Tournier. Nesta pesquisa, procurou-se analisar o romance Le Roi des Aulnes, publicado em 1970, que narra a trajetória de uma personagem fantástica em busca de seu destino em plena segunda guerra, no centro do império nazista. $O$ trabalho foca as estratégias empregadas para construir uma narrativa que vincula tão fortemente questões históricas com elementos míticos, além de investigar 0 potencial crítico da obra. A partir de bibliografia específica, procurou-se situar 0 conceito de mito, observar seus aspectos religiosos e políticos e analisar a configuração que o autor deu ao mito em sua obra. De modo geral, a recriação mítica se mostrou um conceito insuficiente para a análise e interpretação literária, pois a limitação do romance em sua esfera mítico-religiosa empobrece a compreensão da obra. A pesquisa revelou ainda que entre mito e história há vários processos de travessia de sentido, que operam graças à fabulação e à criatividade do autor, de modo que os elementos históricos foram incorporados à obra de maneira distorcida, velada, por vezes mitologizada, assim como os elementos míticos e fantásticos conduzem uma crítica severa à ideologia e política nazistas. Os aspectos míticos da obra trabalham em função sobretudo de criar as balizas morais dentro das quais as personagens atuam, além de abrir um espaço para que o leitor participe da construção do sentido da obra na medida em que ele é envolvido pelas regras do sistema mítico configurado. Por sua vez, a historicidade da obra conta sobretudo com a instabilidade dos elementos formais, bem como dos paradoxos e vicissitudes engendrados pelos elementos míticos para indicar, muito mais do que 0 registro de uma época, a projeção literária de uma dilema histórico. Em outras palavras, este romance é profundamente crítico e historicizante justamente porque ele não conta com uma linguagem realista, descritiva e estável; é no reconhecimento da precariedade da expressão, no momento em que apenas uma linguagem multireferenciada e delirante consegue abordar um contexto histórico problemático que a possibilidade de lucidez e elaboração desponta no horizonte.

Palavras-chave: Mito. Narrativa. Literatura Francesa Moderna. História. Nazismo. 


\begin{abstract}
LIMA-VILLI, A. S. Myth, history and narrative in Le Roi des Aulnes, from Michel Tournier. 2010. 182 f. Dissertação (Mestrado) - Faculdade de Filosofia, Letras e Ciências Humanas, Universidade de São Paulo, São Paulo, 2010.
\end{abstract}

The re-elaboration of myths deeply characterizes the work of the French writer, Michel Tournier. The present research focused itself on the analysis of his novel $L e$ Roi des Aulnes, published in 1970, which narrates the trajectory of a fantastic character in a quest for his fate in the middle of World War II, at the center of the Nazist Empire. The research focused on the strategies employed to build a narrative that so strongly links historic issues with mythic elements, aside from investigating the critical potential of that work. From a specific bibliography, it tried to place the concept of myth, observe its religious and political aspects and analyze the configuration that the author gave to myth in his work. In general, mythic re-creation showed itself to be an insufficient concept to the literary analysis and interpretation, since limiting the novel to its mythic-religious sphere leads to poor comprehension of the work. The research also revealed that between myth and history there are several sense transference processes, which operate thanks to the author's storytelling and creativity, so that historic elements were incorporated to the work in twisted, veiled and at times mythologized ways, just as mythic elements conduce severe critics to nazist ideology and politics. Mythic aspects of the work operate above all to create moral guidelines within which characters act, besides making room for the reader to participate in the construction of the sense of the work, as he gets involved by the configured mythic system. On its turn, the historicity of this work counts above all with the instability of formal elements as well as of the paradoxes and vicissitudes engendered by mythic elements to indicate, far more than the record of a time, the literary projection of a historic dilemma. In other words, this novel is deeply critical and historicizing precisely because it does not employ realistic descriptive and stable language; it is in the recognition of the precariety of expression - on those moments that only multireferenced and delirious language can approach a problematic historic context - that the possibility for lucidity and elaboration shimmers on the horizon.

Keywords: Myth. Narrative. French Modern Literature. History. Nazism. 


\section{SUMÁRIO}

1. INTRODUÇÃO

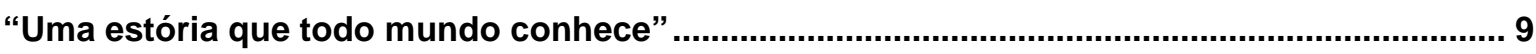

A dimensão mítica no projeto literário de Tournier ................................................................. 14

A dimensão mítica no romance Le Roi des Aulnes.........................................................................19

2. AS SEMENTES EM “ÉCRITS SINISTRES"...................................................28

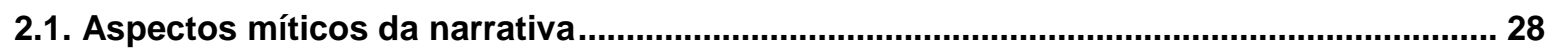

2.1.1. A formação da identidade feérica pela escrita

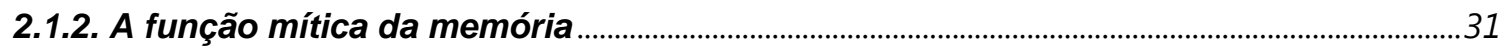

2.1.3. Manifestação do destino e hermenêutica .......................................................................................

2.1.4. Ação ritual e configuração mítica: 0 ato fórico.......................................................................... 41

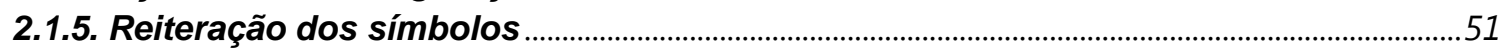

Foria

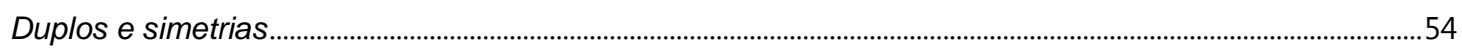

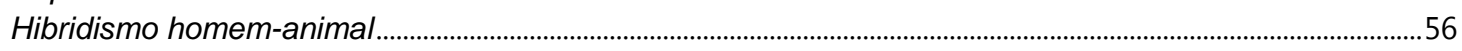

Os espaços mágicos ........................................................................................................................................... 58

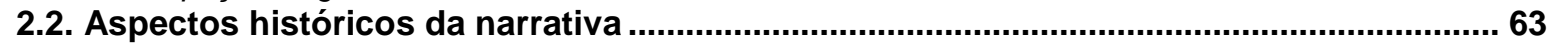

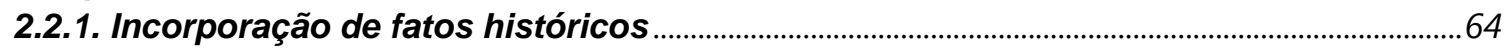

2.2.2. Os limites da expressão

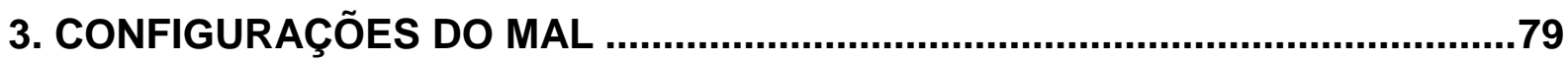

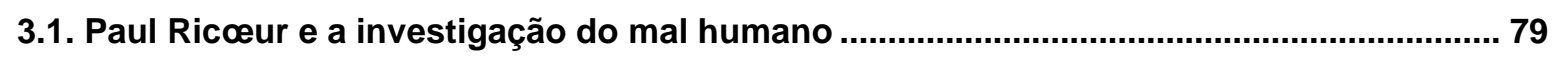

3.1.1. A narrativa do Mal, o mal na narrativa: tipologia

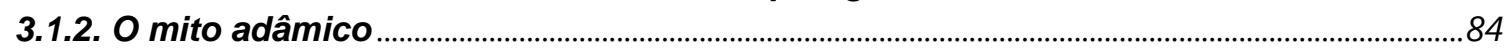

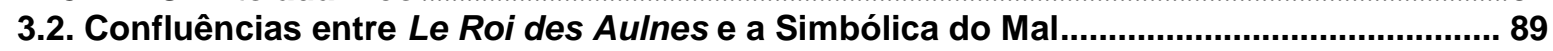

3.2.1. Variações do mito adâmico e do mito platônico …………………..........................................90

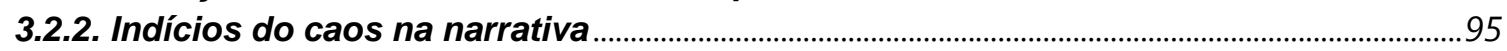

3.2.3. A necessidade e a estetização da barbárie ………................................................................ 100

3.2.4. Inversão maligna, inversão benigna

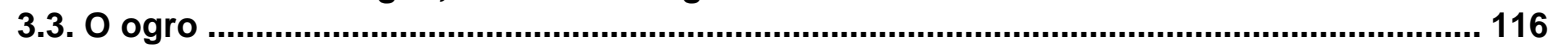

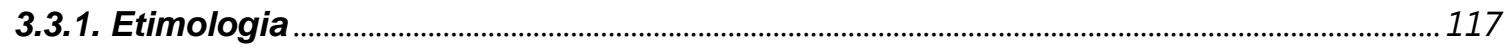

3.3.2. Figurações do ogro: Tiffauges, Göring e Hitler............................................................... 120

Abel Tiffauges, o ogro fórico........................................................................................................................................ 121

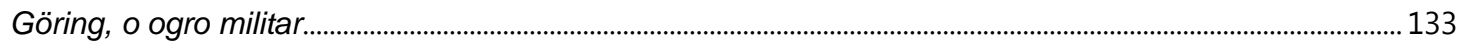

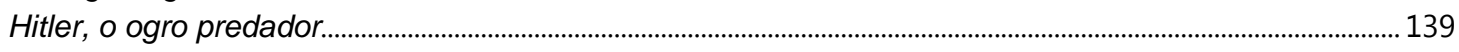

4. VERTIGEM NA VOZ E NO TEMPO DA NARRATIVA ....................................147

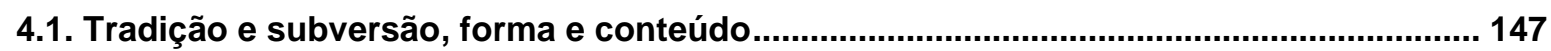

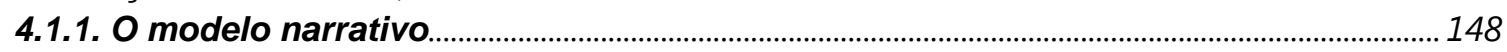

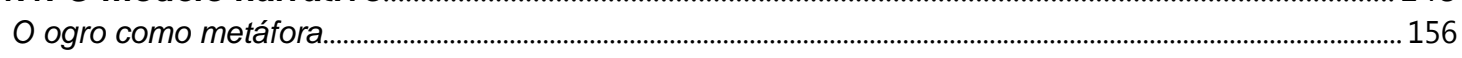

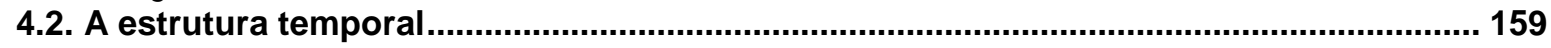

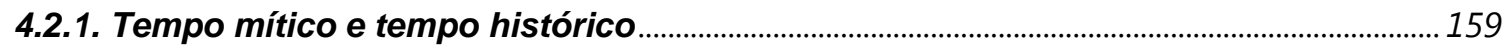

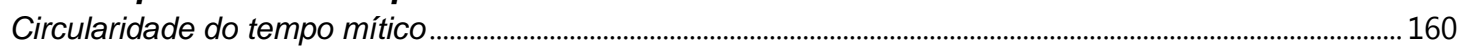

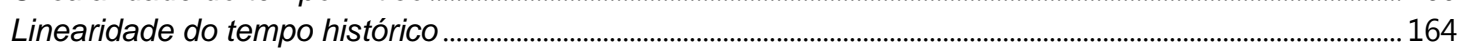

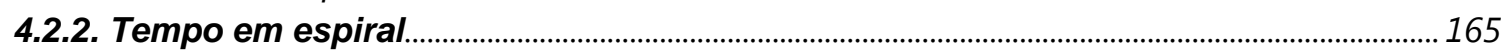

Da história ao mito: a paródia................................................................................................................................................. 169

5. CONCLUSÃO

REFERÊNCIAS.......................................................................................... 181 


\section{INTRODUÇÃO}

\section{"Uma estória que todo mundo conhece"}

Trata-se de uma feliz coincidência: o título desta parte do texto foi emprestado do próprio Michel Tournier (1977), e nenhuma outra definição caberia melhor à introdução necessária sobre o assunto. Eis um conceito que faz desdobrar em vasta literatura os mais variados saberes das humanidades, pois ainda que a pergunta "o que é mito?" seja simples, a resposta quase nunca o será.

Dos estudos de cunho antropológico surgiu uma concepção segundo a qual o mito, articulando a expressão de valores absolutos (tais como a Verdade, a Justiça, o Amor, a Morte, a Vida, o Sagrado), estrutura todo um sistema institucional. Isso porque essas abstrações tornavam-se extremamente concretas nas representações divinizadas que compunham o panteão das civilizações antigas e cuja função maior era de intermediar a relação dos homens com seu mundo exercendo uma função etiológica, ou seja, explicando e justificando. Às questões que a razão humana não podia decifrar, respondia-se com uma mensagem cifrada, constituída de uma linguagem particular e a combinatória de símbolos caros à sociedade. Somente ao mito cabia esclarecer "porque os deuses são os deuses, porque os homens são infelizes e mortais e porque existem heróis entre os homens e os deuses" (VERNANT, 2002, p. 45). Assim, o processo de sacralização de certos elementos e de composição de um discurso genuinamente religioso engendra, finalmente, o mito na cultura. 
Sob essa roupagem de origem última e essencial, contudo, há uma capacidade disciplinar poderosa, que intercede nas estruturas culturais mais profundas, no sentido em que configura o pensamento e a visão de mundo de uma comunidade, uma civilização inteira. É preciso então reconhecer que a instauração do universo mítico se faz pela interdição, pois se a princípio o mito surgiu para dar conta de respostas que os homens não haviam conseguido encontrar racionalmente, eles agora não ousariam mais fazê-lo visto que, agindo dessa forma, profanariam uma verdade primordial e desobedeceriam às regras sociais. Isso porque o mito determina não só a razão de ser das coisas tais quais elas são, mas também um código de ética, um conjunto de saberes que deve ser transmitido de geração em geração, a fim de que se garanta a perpetuidade dessas mesmas coisas. Ou seja, ele se revela o principal instrumento de "criação da abóbada de um mundo comum" (RAMNOUX, 1977), onde os indivíduos poderão se subjetivar inteiramente de acordo com os protocolos sociais.

Neste sentido, o mito contém um aspecto institucional que por vezes fica velado por trás da sacralidade. Ele auxilia o processo civilizatório ao conduzir organicamente as várias etapas da consolidação da cultura e da formação de uma unidade social, ou de um espaço público. A subjetivação de cada um se realiza necessariamente sob essa égide, sob a condição de aceitar o mito como sagrado e necessário. Qualquer ação contrária, ou seja, a recusa a esse pacto, ameaçaria reduzir o mito a uma arbitrariedade e, por conta disto, a existência humana estaria fadada a esvaziar-se. O pacto há de ser, pois, coletivo e irresistível (SEVCENKO, 1987). Coletivo na medida em que é civilizatório, parte da história e identidade essencial de um povo; irresistível porque, como o canto ritualístico, ele carrega a latência do sagrado, mobilizando em torno de si as expectativas de cada indivíduo. Em outras palavras, 
importa que ele reúna e envolva todos os homens, sem exceção, para que nenhum homem seja excluído nesse grande sistema de comunhão de idéias, anseios, crenças, hábitos - da vida em comunidade, enfim.

Não por acaso o mito se serve das práticas rituais para continuar existindo. O rito é justamente a celebração da existência no espaço público, ou a revitalização das práticas humanas exercidas coletivamente. $O$ espaço e o tempo do rito são diferenciados, constituem uma suspensão no espaço e tempo cotidianos para instaurar uma verdade paralela, exterior e fulminante - a esfera mítica. Há movimentos que o corpo deve fazer, palavras que devem ser pronunciadas e símbolos que devem ser vistos ou tocados, tudo feito minuciosamente de um jeito e não de outro, porque é esta encenação que evoca a memória e a sabedoria coletivas e, finalmente, (re)erotizam a relação do homem com o mundo comum.

Quando afirma que "o mito é uma história que todo mundo conhece", Tournier simplesmente oferece uma definição que traduz esse caráter de "bem comum", partilhado e difundido, que têm os mitos junto às respectivas sociedades. Entretanto, o modelo de análise que se propõe aqui prevê outra função, além dessa primeira: a função narrativa. Neste sentido, pouco interessa a seqüência de uma frase que começasse dizendo "o mito é uma história que...", pois as possibilidades de expressão são numerosas e quase sempre válidas. Mas nenhum autor que procurou traduzir o conceito de mito negligenciou seu aspecto de relato, de que se poderia deduzir que sua relação com o "contar histórias" é íntima, e consistente (NUNES, 1987).

Portanto, a recepção do mito não difere da recepção da narrativa comum, pelo menos num primeiro momento. Parece bem claro que se trata de um arranjo de 
elementos ficcionais submetido a determinadas regras de composição, ou seja, ele é aceito como relato mais ou menos anônimo ${ }^{1}$ e retransmitido numa cadeia infinita de locutores e ouvintes. Contudo, pertencer ao domínio ficcional não impede a distinção que, mais cedo ou mais tarde, colocará em patamares diferentes a fábula e o relato mítico. Justamente, as histórias que conta e os personagens de que fala conseguem tocar limites porque experimentam um status cultural privilegiado junto à sociedade da qual é oriundo. Para estas pessoas, a configuração da narrativa mítica é necessária e sacralizada, visto que possui a sabedoria e incita o sentimento religioso de ligação com o sobre-humano.

Em suma, uma fábula só adquire significação mítica quando, tal uma chave que abre o baú de um tesouro, ela encerra uma combinatória, uma história que decifra um enigma ou que conta um segredo. A comoção que decorre disso é celebração, é o regozijo concedido aos homens pelo vislumbre da sacralidade, atrelado profundamente à vertigem da apreensão da efemeridade. Que se observe apenas o caráter eventual desse encontro com a Origem, a Essência: o mito abre a máquina do mundo, mas como um rompante, através da suspensão da inércia mundana para que a experiência do sublime se instaure, fulminante, e desapareça tão logo se quebre o efeito de transe, de encantamento (SEVECENKO, 1987). Logo, é como avesso do discurso profano, como um teatro de sombras projetadas na realidade mais vulgar que o mito se mantém enquanto não está en train d'être, em plena

\footnotetext{
1 As considerações de Nicolau Sevcenko a respeito da importância do xamã nas comunidades arcaicas são muito significativas. Segundo ele, o xamã compõe narrativas com ritmos, desenhos, ritos, luzes, mesmo antes de a linguagem verbal estar plenamente desenvolvida. Seu desempenho seria, portanto, um protótipo de autoria? Cremos que não, pois mesmo que o xamã veicule os mitos, ele representa um transmissor da verdade, e não o criador dela. Sua ligação com a esfera divina é intermediária, e não simbólica.
} 
evocação ritualística. A epifania mítica pressupõe a destruição - ainda que temporária - da ordem do mundo cotidiano, do senso de realidade dos homens.

Há, nisso tudo, uma contradição aparente: como seria possível conceber que o mito "construa a abóbada de um mundo comum" e, ao mesmo tempo, trabalhe no sentido de destruí-lo, atacando-o justamente a partir de sua base mais sólida, ou seja, a vida devidamente normalizada? Pois bem, o impasse talvez pudesse ser desfeito caso o mito não fosse analisado, como se faz geralmente, dissociando-se umas das outras as facetas que o constituem. Ao invés disso, ele poderia ser compreendido como um sistema dialético cujos movimentos e funções se sustentem e se neguem alternadamente.

Dito de outro modo, viu-se que o mito desempenha uma função institucional inegável, cuja potência política e pedagógica torna-se a força motriz da criação da ordem social e de sua manutenção através da adequação do indivíduo. Mas, uma vez garantido o solo fértil que há de acolher a civilização, é preciso não permitir que os homens limitem a compreensão de si mesmos e do mundo ao plano do senso comum, do que é visível e habitual, sob pena de fazer a existência humana se reproduzir no vazio. A transgressão que o mito propõe significa uma superação das interdições e dos tabus que ele mesmo havia criado nas origens do processo formador da cultura, alcançando, assim, um processo dinâmico e incessante de criação, consolidação e renovação daqueles valores abstratos que regem o espírito: a Verdade, a Justiça, o Amor, a Morte, a Vida, o Sagrado... 


\section{A dimensão mítica no projeto literário de Tournier}

Extrapolando o processo ritual, o mito deveu principalmente à tradição oral a garantia de sua organicidade. Todo relato que pudesse ser articulado pela linguagem era imediatamente incorporado ao vasto acervo da cultura, isto é, todo homem representava um dos elos da "infinita cadeia de locutores e ouvintes".

Além disso, não eram poucas as situações que veiculavam o tipo de comunicação propício ao enriquecimento da cultura popular: rodas de contadores de causos, conselhos e sermões dos mais velhos, boatos e histórias dos viajantes, notícias trazidas de longe, troca de receitas, histórias que se contam às crianças, explicações geográficas, climáticas, agronômicas que os sábios formulavam para os problemas...

A tradição oral, enfim, serviu ao mito não apenas porque engendrou e deu matériaprima à fabulação, mas também porque dispunha de um sistema dinâmico de transmissão de informações, bem como agentes/oradores legitimados pela comunidade. Com isso, potencializava-se o traço institucional do mito e dos movimentos que ele promovia porque todas as histórias e conversas - independente de seu conteúdo - tinham no fundo um substrato comum, isto é, o imaginário popular e os códigos de ética permeavam e lapidavam mesmo os discursos laicos. Quanto às narrativas míticas, elas eram ampla e profundamente difundidas, mais até do que as narrativas profanas, porque elas deviam ser do conhecimento de todos, enquanto que todas as outras podiam ou não, circunstancialmente, ser lembradas e contadas. 
O enfraquecimento da tradição oral ao longo dos séculos e sua quase extinção nas décadas mais recentes não provocaram, entretanto, o respectivo desaparecimento do mito da cultura, de um modo geral. Embora ainda presente, o mito sofreu uma série de transferências, apropriações e dissoluções por conta das transformações políticas, sociais, científicas, artísticas, culturais... Com efeito, a mitologia encontrou outros espaços capazes de acolher e gerar suas engrenagens. Considerando a ligação visceral entre mito e narrativa, não estranha que a literatura seja, por excelência, o domínio de que se serve o mito para viabilizar a etapa de reciclagem de seus símbolos e valores.

Michel Tournier vê na união literatura e mito o germe para uma ação cultural interessante, e necessária. As idéias que ele próprio tem a respeito estão por toda parte em sua obra, seja declaradas em seus ensaios ou praticadas em seus textos ficcionais. Grosso modo, seu projeto literário prevê que a narrativa seja um espaço vital e abundante em recursos que reformulem e sustentem as estruturas essenciais da mitologia. Esse "socorro" prestado não implica necessariamente a subordinação da literatura ao mito, mas coloca-os numa espécie de simbiose. Segundo ele, o mito intermedia a metafísica e a literatura, apresentando a si próprio como entidade que conjuga a capacidade de expressão da arte e a profundidade do discurso filosófico. O escritor não diminui a importância que tem a filosofia para a (sua) obra literária, é ela que se mantém velada e pulsante por detrás das narrativas, contendo as abstrações que a literatura veicula na fabulação. Ora, o mito é por excelência a configuração "palpável" e personificada dos valores abstratos, Tournier apropria-se dele justamente para compor obras híbridas e niveladas, das quais a leitura - 0 escritor mesmo afirma (TOURNIER, 1994) - pode atingir diferentes graus de profundidade e complexidade. 
Contudo, a passagem do mito em sua forma pura para uma configuração literária não há de ser completamente natural. Perde-se, por exemplo, a formulação coletiva e, portanto, anônima das narrativas míticas, substituída por um autor reconhecido e um narrador (nas obras mais tradicionais) que conduz a nova narrativa. Apesar disso, a literatura, a filosofia e o mito parecem convergir para um ponto em comum, que seria o de formular e veicular questões e idéias que coloquem em evidência as fissuras e contradições da sociedade moderna. A bandeira que levanta é assumidamente rebelde:

Mon propos n'est pas d'innover dans la forme, mais de faire passer au contraire dans une forme aussi traditionnelle, préservée et rassurante que possible une matière ne possédant aucune de ces qualités. (TOURNIER, 1977 p. 195)

Essa semente subversiva estaria igualmente presente no mito, por conta do aspecto transgressor, e na literatura (tal é concebida por Tournier), por conta da bagagem metafísica e do humor ${ }^{2}$. O escritor desenvolve toda uma teoria a respeito do riso, da qual vale apreender especialmente seu princípio "curador". A risada agiria como verdadeiro antídoto para placebo, estancaria alguns dos males da sociedade moderna: a pasmaceira, o individualismo excessivo, a paranóia...

As razões de ser que Tournier atribui ao mito e à literatura, nos tempos atuais, são calcadas num mesmo conceito de desassossego, de destruição da ordem e do conhecido, de renuncia à vida previsível e supercontrolada. As histórias que propõe são buscas metafísicas, visando que seja essencialmente humano, primordial e indispensável:

\footnotetext{
${ }^{2}$ Veremos, mais adiante, que também a forma do texto tournieriano contém características pouco tradicionais, preservadas e consolidadas.
} 
Lorsque les lattes disjointes de la passerelle où chemine l'humanité s'entrouvrent sur le vide sans fond, la plupart des hommes ne voient rien, mais certains autres voient le rien. Ceux-ci regardent sans trembler à leurs pieds et chantent gaiement que le roi est nu. (TOURNIER, 1977, p. 199)

Se o caminho possível para que se alcance o êxtase da celebração está na aceitação do nada, então necessariamente o mito se apresenta como uma reedição, uma versão dessacralizada daquilo que foi, outrora. Isso porque a celebração mítica estaria indissociada do vislumbre do sobre-humano, da intervenção divina no cotidiano. Porém, anulada qualquer entidade externa à esfera terrena, a busca metafísica se encerra na contemplação do nada, e volta para formular na condição humana a possibilidade de redenção. O grau máximo de superação que o mito pode propor está contido nele mesmo, é um processo auto-referente como afirmação e potencialização de alguns aspectos da existência dos homens, como a liberdade, a lucidez.

Do mito, Tournier considera tão somente a função contestadora que se choca contra os protocolos, negando absolutamente seu desempenho "conformador". Em especial no campo da literatura, há personagens que, segundo ele, simbolizam bem a recusa aos modelos de vida modernos - Don Juan, Don Quixote, Fausto, Robinson Crusoé - porque colocaram acima da expectativa da sociedade suas paixões e realizações, "assumindo a responsabilidade por um pecado" (RAMNOUX, 1977).

Disso decorre que o mito não tem necessariamente um caráter institucional. Vai no sentido oposto da ordem social porque não vela pela coletividade, não trabalha a favor da adequação e tampouco deve fazê-lo, pois segundo Tournier (1989, p. 123, tradução nossa), a intransigência às leis é o pleno exercício da liberdade de escolha: 
"O homem é de tal forma constituído que, caso venha a ser privado de sua faculdade de dizer "não", nunca mais fará nada que valha a pena."

Não significa, contudo, que o autor desconsidere a atuação do universo mítico como espaço de subjetivação dos indivíduos. Na verdade, Tournier atribui todo o processo de formação da sensibilidade e da identidade ao sistema de comunicação desenvolvido no seio da tradição oral, porque ele guarda ainda resquícios e heranças do tempo passado, como ecos das vozes primordiais e essenciais da alma:

L'homme est un animal mythologique. L'homme ne devient l'homme, n'acquiert un sexe, un cœur et une imagination d'homme que grâce au bruissement d'histoires, au kaléidoscope d'images qui entourent le petit enfant dès le berceau et l'accompagnent jusqu'au tombeau. La Rochefoucault se demandait combien d'hommes auraient songé à tomber amoureux s'ils n'avaient jamais entendu parler d'amour... pas un seul, car ne jamais entendre parler d'amour, ce serait subir une castration non seulement génitale, mais sentimentale, cérébrale, totale. (TOURNIER, 1977, p. 43)

Ora, o processo de subjetivação pressupõe valores cujo sentido é partilhado (como o amor) e práticas rituais (como a iniciação, tão recorrente, aliás, na obra de Tournier), ou seja, pressupõe a existência de um mundo comum. E se o mito conta com esse mundo para encharcar de significado a vida dos homens, então ele também conduz, de alguma forma, à coletividade. Cada homem devidamente inserido no sistema cultural será uma peça a mais para fortalecer e dinamizar as engrenagens de que o mito se serve para perpetuar-se. 


\section{A dimensão mítica no romance Le Roi des Aulnes}

A discussão feita até aqui a respeito do mito e de seus limites na obra de Tournier é apenas um conjunto de apontamentos necessários e introdutórios ao assunto, pois naturalmente a configuração do romance Le Roi des Aulnes acaba por determinar outras aplicações, especificidades, distorções do conceito. Temos, por ora, apenas as balizas com as quais trabalharemos para desenvolver a leitura proposta.

Em linhas muito gerais, o livro narra a história de Abel Tiffauges: acompanhamos, assim, suas memórias da infância passada no internato São Cristóvão, onde ele conheceu Nestor, um garoto que acredita em predestinação e o convence de que há um destino grandioso refletido em pequenos sinais, que devem ser decifrados. Nestor morre num incêndio - que Abel acredita ter sido providenciado pelo destino mas deixa no amigo a certeza de que é possível desvendar o segredo do mundo, e realizar os projetos a ele destinados. Quando adulto, Abel trabalha como mecânico em Porte-des-Ternes, época em que descobre e desenvolve suas perversões ogras através da escrita de seu diário, chegando a ser injustamente condenado pelo estupro de uma menina. Como nesta época começava a Segunda Guerra, ele é transferido da prisão para o exército e enviado à fronteira, onde passa a selecionar pombos que pudessem servir no sistema de comunicação dos Aliados. Essa é a fase columbófila de Abel.

Todos os homens da base onde ele trabalhava são capturados numa investida do exército alemão e enviados a um campo de prisioneiros na Prússia Oriental. Abel, que se mostra satisfeito com a sua condição, torna-se logo um colaborador. Tiffauges passa por várias regiões do império nazista, explorando vilas e bosques 
enquanto presta pequenos serviços ao Reich. É numa cabana no bosque próximo ao campo de prisioneiros que ele conhece o Oberforstmeister, guarda florestal que o leva para a reserva florestal de Rominten, a serviço de Göring, um dos altos generais do Reich. Também é de um dos charcos nas terras alemãs percorridas por Tiffauges que é retirado por arqueólogos o corpo de um homem das turfeiras, batizado por estes de Rei dos Álamos, com quem Tiffauges se identifica e que dá nome à obra.

Ao longo do tempo, ele aprofunda suas convicções acerca de seu destino e seu contato com o sistema ideológico nazista. Através do marechal Göring, Abel consegue um emprego numa napola como responsável pela seleção de crianças que formarão a juventude hitlerista, o que lhe consagrará como Ogro de Kaltenborn. Tiffauges, ainda que crítico da ideologia nazista, mantém-se na napola por acreditar que nela seu destino se realizaria de alguma maneira - o que acontece, enfim, na cena final do romance quando ele tenta salvar a vida do menino Éphraïm, exprisioneiro de Auschwitz, repetindo a cena mítica de São Cristóvão carregando uma criança.

Fato é que a representação de Tiffauges, as experiências pelas quais ele passa, as coisas que diz, faz, sente - tudo, enfim, aponta para uma profunda ambigüidade. Comecemos por seu nome: "Abel" é uma referência direta ao filho de Adão e Eva, que Tournier chamou de "primeira vítima de assassinato da história ocidental" (TOURNIER, 1994, p. 119). Ainda de acordo com a análise do escritor, Abel seria um rapaz de espírito pacífico, livre, estável. Entretanto, Tiffauges é o nome do castelo em que supostamente Gilles de Rais, outrora companheiro fiel de Joana D’Arc, na França do século $\mathrm{XV}$, teria assassinado um número indefinível de 
crianças. Ora, é verdade que este personagem desempenha, ao longo do texto, várias "perversões" (TOURNIER, 1994, p. 122): pedofilia, necrofilia, coprofilia, voyeurismo, vampirismo, sadismo, masoquismo; mas é também verdade que todas estas transgressões reunidas não fazem dele um personagem genuinamente maldoso, pelo contrário: há nele algo de inocente. Em outras palavras, Abel Tiffauges parece se desvencilhar das noções estanques de Bem e Mal para fazer valer um conjunto de valores e ações que não se justificam por parâmetros morais e éticos "médios", mas sim dentro de uma lógica de pensamento paralela, coerente com o sistema cognitivo da obra. A singularidade de Abel é de tal forma acentuada, que acaba por caracterizar mais do que uma personalidade extravagante - ele é uma "criatura feérica", um "ogro" cujas características físicas e morais são estranhas e que crê absolutamente ser destinado a algo excepcional.

Essa certeza da predestinação nos interessa mais particularmente na medida em que ela se torna o ponto de interseção inicial entre o curso da humanidade e a história pessoal do personagem, âmbito em que os fatos históricos e os ficcionais, bem como a voz narrativa e a temporalidade se confundem, apresentando-se como elementos híbridos e complexos.

A associação entre a obra de Michel Tournier e o processo de recriação mítica tornou-se já um lugar comum entre os leitores e estudiosos em literatura francesa, de tal modo o autor serve-se do recurso. Todas as suas obras, sem exceção, vinculam de algum modo elementos de realidade - de cunho histórico, político e/ou cultural - e estruturas e personagens míticas, oferecendo assim material para reflexões filosóficas a respeito da contemporaneidade. E, ainda que sua pena habitualmente escolha a ironia, a polêmica e o incomum como elementos 
constitutivos de seu estilo, pode-se dizer que o romance Le Roi des Aulnes é o mais ousado de sua obra. Os campos de concentração, o programa nazista e suas práticas não desempenham funções estanques de locus ou topos da narrativa; como veremos, a Shoah integra o sistema cognitivo da obra, com uma trajetória dinâmica no enredo, como suporte do eixo temporal, e configuração literária específica.

Em sua autobiografia, intitulada Le vent Paraclet (TOURNIER, 1994), o autor conta que a motivação primeira do romance vem de um dado biográfico: Tournier era adolescente quando a campanha do exército alemão ocupou parte da França. Ele conta que, por ser filho de germanistas e por ter morado na Alemanha durante algum tempo, ele e a família assistiram com certo receio as movimentações políticas e militares da época:

Vint l'année noire de la défaite. La déferlement sur la France de l'armée allemande équipée d'un matériel éblouissant, rendu plus jeune encore par sa rapide victoire sous le soleil de juin, fut pour beaucoup de Français une révélation stupéfiante. Ils n'avaient de l'Allemand qu'une idée abstraite, étriquée par une propagande ignare et maladroite, et que voyaient-ils ? Un peuple en marche chantant en chœur et balayant tout sur son passage. Nous, nous savions. Nous étions vaccinés contre la séduction nazie. Nous l'avions vue naître. Nous connaissions ses à-côtés, nous soupçonnions ses arrièreplans. (TOURNIER, 1994, p. 75)

Embora desaprovasse as idéias e práticas do Nacional Socialismo, Tournier conta que tinha ligações fortes com o país e a língua germânica, de modo que empenhouse em voltar, o que finalmente consegue em 1946, por conta de uma bolsa de estudos em filosofia - quando ele concebe, portanto, a idéia de um romance que escreveria 24 anos mais tarde. "J'ai su très tôt que si je déversais mon expérience, mes déceptions et mes enthousiasmes ayant l'Allemagne pour objet, le personnage 
principal en serait un prisonnier français en 1940..." (TOURNIER, 1994, p. 105). Não interessa, absolutamente, fazer uma análise da obra à luz da biografia do autor. Ele mesmo afirma que "la part littéralement autobiographique du roman est mince" pois as similaridades entre personagem e autor não estão muito além da experiência de exílio, que se dá, aliás, de modos muito diversos para um e outro. Interessa, todavia, situar o mais precisamente possível o lugar de onde fala Tournier quando decide escrever um romance sobre a Segunda Guerra Mundial.

Ele não é, certamente, um dos envolvidos imediatos nas práticas nazistas, isto é, sua voz não se levanta no esforço do testemunho do sobrevivente; tampouco é a rememoração do algoz. Desconfiado, não aderiu à propaganda ideológica do Reich, mas tampouco tomou contato com os prisioneiros e perseguidos pelo regime além do que era possível a um cidadão francês. Esteve, então, no mesmo ponto intermediário em que esteve a maioria das pessoas enquanto o Reich avançava - e sobre sua postura na época, mais não nos conta.

O romance Le Roi des Aulnes parte, assim, de um ponto também intermediário e neutro, na medida em que o herói, Abel Tiffauges, se mantém fora do círculo de acontecimentos que marcam a Europa entre os anos de 1938 e 1939 e dedica-se, em contrapartida, a fatos de sua vida pessoal, a um exercício de memória e escrita: seu diário.

Embora a impressão de neutralidade não se sustente por muito mais tempo, o papel do "intermédio" na obra é constante e necessário. Mas isso - a tomada de posição ante a um conteúdo político e moral - é percebido, primeiro, através da análise estrutural da narrativa, a começar pelo suporte mítico que Tournier lhe confere. 
Há, de antemão, um substrato mítico poderoso respectivo ao romance: não devemos nos esquecer que o êxito do programa político nazista contou com uma campanha ideológica divulgada e defendida em centros culturais e artísticos, veiculada por meios de comunicação em massa - como o cinema, a televisão e a publicidade. Sobretudo, o apelo ideológico dirigia-se mais fortemente à juventude, segundo os relatos das impressões de Tournier quando de sua passagem pela Alemanha nazista:

J'avais nettement senti combien le nouveau régime allemand était axé sur moi et mes semblables. En effet c'est une des caractéristiques du fascisme de surévaluer la jeunesse, d'en faire une valeur, une fin en soi, une obsession publicitaire. Un mouvement jeune, par les jeunes, pour les jeunes, tel était le slogan le plus souvent répété en Italie. (TOURNIER, 1994, p. 105)

Ora, esse aparato ideológico-publicitário de que dispôs o regime nazista, suas máximas repetidas à exaustão e, finalmente, o recorte de um público jovem e suficientemente sensível às idéias de uma nação renovada, pura, limpa, próspera tudo, enfim, aponta para um esforço em criar um mito nazista, condizente com uma das modalidades que há pouco expusemos: o mito formador, institucional, irresistível, coletivo.

A assimilação do mito pelo nazismo certamente não é casual, e o sucesso com que um estruturou o outro - e como se potencializaram mutuamente - suscitou ao menos alguma perplexidade em Adorno e Horkheimer. No ensaio "Após Auschwitz", Jeanne-Marie Gagnebin observa que o texto de Dialética do Esclarecimento é todo marcado por uma "dificuldade, isto é, algo que assinala uma indecisão, (...) uma oscilação na determinação do mito e da mitologia, entre sua definição como forma de pensamento já permeada de racionalidade, ou então como forma "primitiva", tributária do medo originário e da crueldade ancestral" (GAGNEBIN, 2007, p.63). Ou 
seja, o mito poderia constituir a antítese do modelo racional iluminista (apresentando-se, portanto, como modelo racional mítico, igualmente atuante no processo dialético) tão bem quanto poderia "apenas" remeter às profundezas do irracional e absurdo (e, desta maneira, não ceder às investigações do pensamento racional).

Apesar - ou justamente por conta - da fonte de violência e crueldade de que o mito certamente é portador, Gagnebin abre uma possibilidade de leitura do mito, naquilo que o assemelha à obra de arte (a saber, o vínculo com a transcendência e "a manifestação do todo no particular"). Considerando, contudo, a "saturação do conceito de mito, devida à sua anexação quase completa pelo regime nazista" (GAGNEBIN, 2007, p.66) o motivo do impasse se justifica, segundo ela, ao receio dos filósofos em "elaborar uma teoria positiva do mito, sob o risco desta ser usada em proveito da ideologia de plantão" (GAGNEBIN, 2007, p.68).

A solução, entretanto, interessa-nos menos do que a pergunta: como formular a resistência ao discurso e às práticas nazi-fascistas sustentadas por um modelo de pensamento mítico que, por sua vez, alcança dimensões de grande magnitude, e pode reivindicar tanto sua roupagem irracional e originária quanto a legitimidade de sua racionalidade enquanto negação dialética do pensamento esclarecido? Nesse ponto, voltamos ao substrato mítico do romance Le Roi des Aulnes. Sustentando o impasse de Adorno e Horkheimer no momento da escrita de Dialética do Esclarecimento, de que maneira as estruturas míticas usadas por Tournier em um romance sobre a Segunda Guerra Mundial podem escapar a esse risco de reforçar a ideologia nazista? Para além do tom entusiasta, da linguagem e abordagem irreverente, a narrativa serve-se de um modelo de pensamento que, a princípio, é empregado em favor de uma ideologia que ele condena. 
Há que se apontar as diferenças entre os aparatos míticos em jogo. Como vimos, a campanha do Reich depositou suas investidas em um modelo de mito formador, institucional e principalmente coletivo. Não é possível, porém, pressupor neste coletivo (a sociedade civil alemã) a diversidade dos modos de existência que constantemente costuma haver, pois o discurso ideológico não era apenas um convite à participação; ele selecionava, pelo teor de suas idéias (e depois por suas práticas de perseguição, captura e extermínio), os indivíduos que podiam compor esta nova nação "bem-sucedida", "limpa", etc. A coletividade no mito nazista foi, assim, escolhida e forjada, na medida em que as pessoas deveriam passar pela identificação do ideal estético e comportamental estabelecido pela campanha publicitária e artística.

Este ideal estético, por sua vez, inspirava-se nos modelos clássicos (gregos e latinos), ou seja, vinculando o presente e sobretudo o futuro (a ser construído coletivamente) a um passado e civilizações idealizados, o mito nazista determinava uma continuidade e tradição para si próprio. Eis a "abóbada de um mundo comum", artificial e imposta por um programa político que se queria mítico, institucional, e cujo coletivo deveria ser o mais homogêneo possível.

A estrutura mítica sobre a qual a narrativa de Le Roi des Aulnes se apóia é diferente: o eixo do romance é a personagem de Abel Tiffauges, que caracteriza a si mesmo como uma criatura obscura, de feições grotescas e membros desproporcionais, desajeitado, introspectivo, míope. Isto é, a função mítica do romance baseia-se nesta figura que, desde já, foge a qualquer possibilidade de identificação - seja com o ideal estético nazista, seja com qualquer pessoa - o que já basta como contraponto à imagem de humano que o Reich se esforçou em projetar. Abel não é 
a norma, por mais largos que sejam os limites que damos a ela. Sua caracterização monstruosa o afasta do humano e do sublime, e, ainda, coloca no centro da trama um exemplar que radicaliza a figura de outro, de estrangeiro, de estranho alteridade esta que, segundo Régnier Pirard (in BOULOUMIE; GANDILLAC, 1990), fundamenta o sentido último do romance. Ora, tal é o modelo de mito transgressor: ele é necessariamente individual e, como tal, assume a função antitética do mito fundador e sua vocação/necessidade de coletivo. Sua importância está depositada principalmente na configuração que veicula desde cedo uma função indisciplinar, que põe em suspenso o dado, o confortável, o familiar. O leitor segue com ele ${ }^{3}$, sem repulsa ou identificação, apenas aceitando sua singularidade.

A experiência estética, experiência da distância do real em relação a nós, experiência também da distância do real tal como é e qual poderia ser, essa experiência pode configurar um caminho privilegiado para o aprendizado ético por excelência, que consiste em não recalcar o estranho e o estrangeiro, mas sim capaz de acolhê-lo na sua estranheza. (GAGNEBIN, 2007, p. 94)

É preciso esclarecer: Abel Tiffauges não é uma personagem mítica, a priori, veremos que na verdade ele se redimensiona, ao longo do romance, a ponto de atingir uma condição mítica. Às duas modalidades de mito que apresentamos serão acrescidas ainda algumas observações de Ricœur a respeito de símbolo e mito; porém sua configuração dá indícios de uma escolha estética que desafia um modelo mítico apropriado pelo fascismo cujas engrenagens o autor conhecia.

3 Não apenas o leitor aceitará Abel, mas o próprio exército alemão fará dele um dos seus, dada sua capacidade. Esta aceitação improvável, creio, é uma das maiores ironias do enredo. 


\section{AS SEMENTES EM "ÉCRITS SINISTRES"}

\subsection{Aspectos míticos da narrativa}

Uma das características mais fundamentais e marcantes do romance é o requinte da estrutura narrativa. Até o momento imediatamente anterior à Segunda Guerra, todos os elementos nos são dados através da voz do próprio Abel Tiffauges, que escreve um diário ao longo de dois anos (entre 3 de janeiro de 1938 e 4 de setembro de 1939) para narrar suas lembranças. Esse texto, inserido na obra sob o título "Écrits sinistres d'Abel Tiffauges", é na verdade o primeiro contato do leitor com a personagem.

A análise da obra não principia nesse diário simplesmente porque esta é a primeira das cinco partes que compõem o romance. Na verdade, por conta da circularidade da narrativa e das muitas referências entre os capítulos, a ordem do enredo deverá ser em parte desconsiderada. É relevante observar, no que concerne o texto de "Écrits Sinistres", que se trata da manifestação, digamos, "autêntica" da personagem - isto é, sem nenhum tipo de mediação de um narrador heterodiegético (GENETTE, 1972).

No mais, trata-se de um texto prenhe de todos os signos e conceitos necessários para a compreensão da obra, ou seja, os capítulos posteriores são uma espécie de conseqüência, desdobramento e confirmação daquilo que está escrito e previsto no diário de Abel Tiffauges. Finalmente - e mais importante, talvez - a escrita do diário é o meio pelo qual Abel definirá sua personalidade feérica, ou seja, essas páginas 
são o próprio processo de subjetivação da personagem, de cuja caracterização mítica dependerão os demais elementos míticos da obra.

\subsubsection{A formação da identidade feérica pela escrita}

Porque queria "pour la première fois prendre la plume pour vider le cœur et promulguer la vérité" (TOURNIER, 1970, p.16), Abel traça as primeiras linhas do diário de maneira que elas - as linhas - não seriam muito mais do que uma experiência quase lúdica de escrita. O que torna o exercício um acontecimento na vida da personagem é que ele inicia os textos de "Écrits Sinistres", assim chamados porque escritos com a mão esquerda (a gauche, a sinistra). Desta maneira, o primeiro fator relevante do diário não é sequer o próprio texto, mas sua gênese, decorrente de uma recém-descoberta capacidade gauchère, expansiva e voluntariosa: "Pour un homme aussi naturellement secret que moi, répandre ses viscères sur du papier, c'est bien rebutant au début, mais ma main m'entraîne" (TOURNIER, 1970, p. 17).

O texto autônomo, concebendo a si próprio, desencadeia o primeiro (pois outros sucederão) ato de rememoração e elaboração: o da perda do objeto amoroso. Rachel foi a mulher que Tiffauges amou, e o fim de seu relacionamento torna-se o conteúdo do primeiro ato de escrita propriamente: "il me semble qu'ayant commencé à me raconter, je ne pourrai plus m'arrêter avant d'être arrivé au bout de mon rouleau... J'ai perdu Rachel. C'était ma femme." (TOURNIER, 1970, p. 17). Dois fatos independentes entre si, mas conjugados, portanto, criam uma espécie de fenda na vida ordinária de Tiffauges para inserir, nela, uma sobre-vida, baseada na função 
autoral. Tal é o acontecimento de que falávamos: o início do diário significa o início de uma identidade e uma vida diferentes da que ele tinha até então: "peut-être aussi les événements de ma vie ne peuvent-ils plus se succéder désormais sans ce reflet verbal qu'on appelle un journal?'

De fato, o diário torna-se uma espécie de portal sob o qual ele faz passar toda sua vida, ou melhor, as partes que ele considera mais relevantes: a princípio, seu relacionamento com Rachel, depois, a infância (cuja importância supera em muito a do namoro). Recordando seu passado, ele intensifica e aprimora o exercício de escrita e, com isso, chega à evasão de um lado de sua personalidade que permanecia, até então, submerso e obscuro: sua monstruosidade. A recuperação mnemônica de Abel interessa na medida em que, mantendo a potência esclarecedora de uma epifania, ela se dá através do ofício do journal, ou seja, está íntima e necessariamente ligada ao ato da escrita. Esta recuperação, esta descoberta, sabemos, é a compreensão posterior das experiências que ele teve na infância, e que precisavam de um abrir de olhos para emergirem e se revelarem.

- Tu n'es pas un amant, tu es un ogre! Ô saisons, ô châteaux! En prononçant cette simple phrase, Rachel a fait surgir le fantôme d'un enfant monstrueux, d'une précocité effrayante, d'une puérilité déconcertante dont le souvenir prend possession de moi avec une impérieuse souveraineté. Nestor. J'ai toujours pressenti qu'il reviendrait en force dans ma vie. En vérité, il ne l'avait jamais quittée, mais depuis sa mort il me laissait du mou, se contentant par-ci par-là d'un petit signe sans gravite - amusant même parfois - pour que je n'oublie pas. Ma nouvelle écriture sinistre et le départ de Rachel m'avertissent d'une prochaine restauration de sa puissance. (TOURNIER, 1970, p. 21 , grifos nossos)

É preciso notar que a monstruosidade não é apenas re-conhecida pela escrita, mas por ela configurada, pois a cisão entre a identidade "normal" e a "alteridade" é fruto também do ato de escrever, como se este fosse a manifestação externa da 
alteridade que há dentro dele. Eis o porquê de Abel escrever um diário de memórias: o papel da rememoração é o de tocar na profundidade da existência de Abel, trazer à tona uma identidade diversa que ele chama de "moi visqueux" e que, escrevendo a si própria, reforça sua existência e a necessidade de revisão do passado.

Le moi visqueux... II y a un autre moi, le moi visqueux. Celui-là n'avait rien compris d'abord à cette histoire de rupture. II ne comprend d'ailleurs rien du premier coup. C'est un moi pesant, rancunier, humoral, toujours baigné de larmes et de semence, lourdement attaché à ses habitudes et son passé... Je le porte au fond de moi comme une blessure, cet être naïf et tendre, un peu sourd, un peu myope, si facilement abusé, si lent à se rassembler devant le malheur. C'est lui à coup sûr qui me fait chercher la trace dans les couloirs glacés du collège Saint Christophe d'un petit fantôme... Comme si je pouvais vingt années plus tard prendre son malheur sur mes épaules d'homme, et le faire rire, rire. (TOURNIER, 1970, p. 37)

Mais adiante, Abel dá uma primeira pista mais bem delineada ${ }^{4}$ a respeito desta, digamos, "alteridade interna": um ser obscuro, retraído, pesaroso, ingênuo, fantasmagórico... Ora, trata-se de uma imagem, ou melhor, um espectro de sua própria infância, que o obriga a descer mais e mais fundo dentro de si, até que recupere e compreenda absolutamente aquilo que fora e, para além do processo de auto-conhecimento, Abel deverá alcançar um estágio de consciência mítica, reestabelecendo uma espécie de pacto com a ordem originária do mundo.

\subsubsection{A função mítica da memória}

Em seu capítulo “Aspectos míticos da memória”, Jean-Pierre Vernant (1990, p. 135), parafraseando I. Meyerson, diz que "a memória, enquanto se distingue do hábito,

4 Essa primeira descrição que Abel faz do "eu viscoso" reaparecerá outras vezes no romance, quando ele assimilar fisicamente algumas das características deste ser. 
representa uma invenção difícil, a conquista progressiva pelo homem do seu passado individual, como a história constituiu para o grupo social a conquista de seu passado coletivo". Assim, vimos que através de sua escrita, Abel tem acesso à sua história individual e dela se apropria para transformar-se, pois agora ele a compreende. O entendimento do passado não se dá por vias "normais", como sucederiam a um homem que se analisasse à luz da psicologia ou da psicanálise; pois assumindo sua identidade de ogro, ele imediatamente altera a categoria de sua existência, recolocando-a na esfera da eternidade, do sobre-humano, do mito.

Vernant, baseando-se nas experiências míticas dos gregos através do ritual de enunciação poética, explica que o acesso absoluto ao tempo não se dá de maneira imediata nem independente, mas, antes, é a intervenção divina que permite que o humano alcance o passado remoto (e mesmo o futuro). A memória, sendo "uma função muito elaborada que atinge grandes categorias psicológicas como o tempo e o eu" (VERNANT, 1990, p.136), se revela ao aedo como uma inspiração poética, permitindo a ele estar "presente no passado". A vidência do poeta, pois, contém e está contida em seu canto, no fazer a poesia e naquilo que ela profere, no olhar que se iguala ao saber e ao dizer. Ao canto poético, inspirado por Musas, é conferido um valor quase ritual, posto que se aproxima do esforço religioso de encontrar as origens da existência. A memória do poeta, portanto, não lhe abre apenas as portas de sua própria vida, mas da história coletiva.

É certo que Tiffauges não é um poeta, que aquilo que diz e escreve não se destina a nenhuma comunidade (pois ele não faz parte de nenhuma) e que não há uma divindade, uma entidade externa e consciente a orientar-Ihe a escrita. Ainda que existam grandes diferenças entre ele e o poeta grego, sua memória também alcança a esfera mítica, incentivada todavia por um movimento de autodeterminação: a 
recuperação de certos fatos da infância provoca uma reconfiguração de sua própria identidade, e a aceitação desta nova modalidade de existência viabiliza, enfim, a travessia do tempo ordinário ao tempo originário.

Tu es un ogre, me disait parfois Rachel. Un Ogre? C'est-à-dire un monstre féerique, émergeant de la nuit des temps? Je crois, oui, à ma nature féerique, je veux dire à cette connivence secrète qui mêle en profondeur mon aventure personnelle au cours des choses, et lui permet de lui incliner dans son sens. (...) je crois aussi que je suis issu de la nuit des temps. (...) Or moi, j'étais déjà là, il y a mille ans, il y a cent mille ans. Quand la terre n'était encore qu'une boule de feu tournoyant dans un ciel d'hélium, l'âme qui la faisait flamber, qui la faisait tourner, c'était la mienne. (TOURNIER, 1970, p. 13-14, grifos nossos)

Nas palavras de Vernant (1990, p.157), "trata-se de situar-se no quadro de uma ordem geral, de restabelecer sobre todos os planos a continuidade entre si mesmo e o mundo, ligando sistematicamente a vida presente ao conjunto dos tempos, a natureza humana à existência inteira, o destino de indivíduo à totalidade do ser, a parte ao todo". Essa continuidade entre as temporalidades e as modalidades de existência, bem entendido, só pode ser estabelecida por um gesto deliberado de busca da dimensão mítica da existência. Se o homem antigo obtinha o acesso ao infinito através do rito, do canto e do corpo, no romance ele obviamente só pode ser costurado na narrativa.

A travessia que leva Tiffauges do presente ao passado próximo, ao passado remoto e finalmente ao futuro cabe, portanto, ao exercício de memoração e interpretação que apenas na escrita ganha substância. Tal é a importância do diário, ou melhor, tal é a importância do registro diário de suas memórias. Certamente não é por acaso que Tournier principia seu romance reunindo essas quatro dimensões temporais: a maneira com que a personagem passeia entre elas aponta, afinal, para a potência do mito. 
Mais bien entendu, je n'avais rien compris, et j'étais loin de soupçonner que je venais d'assister à la formation d'une première fissure dans le bloc monolithique du destin qui m'écrasait. Dès ce jour mémorable, j'aurais pu cesser de le considérer comme un enchaînement inéluctable et a priori hostile et reconnaître - comme j'y ai été contraint depuis - qu'il pouvait entretenir une certaine complicité avec ma petite histoire personnelle. (TOURNIER, 1970, p. 44)

Em suma, Tiffauges executa, a partir da escrita do diário e da função autoral, o salto de retorno ao espectro infantil que se confunde já com a origem última do espírito, a transformação de sua identidade presente e a adesão "à ordem das coisas" 5 futuras. Dentro dos "Écrits Sinistres" está a primeira cisão da modalidade narrativa: a alternância entre o presente e o passado. Se a dimensão mítica se instaura e prevalece sobre os dados cotidianos e triviais, se a monstruosidade de Abel se torna um fato a ser aceito, é porque ele conseguiu, enquanto narrador, tecer uma narrativa que sustentasse sua personalidade ogra.

Do ponto de vista da constituição da personagem, a primeira cisão temporal se projeta de duas maneiras: uma representação da criança que foi Abel, feita por ele mesmo, e uma representação do Abel Tiffauges adulto, garagista em Porte-deTernes, a ser constatada pelo leitor. Uma vez que o processo de formação da identidade feérica está em pleno curso, é razoável que as duas figurações da personagem, a criança e o adulto, se determinem mutuamente e procurem orientar o leitor a também aceitar o fato da monstruosidade de Abel.

Assim, temos a impressão de acompanhar seu desenvolvimento a partir de uma série de lembranças e pressupostos que nos são dados como certos, delineando rigorosamente uma consciência desde sempre tortuosa, obscura, sinistra. Com

\footnotetext{
${ }^{5} \mathrm{O}$ movimento do retorno, aliás, surge aqui apenas sua primeira expressão. Abordaremos os constantes retornos que a personagem cumpre quando abordarmos o mito adâmico.
} 
efeito, desde a primeira linha Abel-narrador manipula e intercala a narrativa de sua infância com reflexões e divagações outras, de modo que sua existência, marcada por excepcionalidades e predestinação, seja evidente aos leitores.

10 janvier 1938. [...] À ce moment-là, je me souviens, j'avais fait le recensement de mes misères et je n'attendais de lueur d'espoir de nul horizon... J'en étais arrivé au point - mais me suis-je jamais départi de cette attitude? - de considérer comme nul et radicalement disqualifié tout auteur, tout personnage historique, toute œuvre, toute matière d'ensegnement quelconque... Je commençai à me constituer une culture en marge, un panthéon personnel où voisinaient Alcibiade et Ponce Pilate, Caligule et Hadrien, Fréderic-Guillaume I et Barras, Talleyrand et Raspoutine...(TOURNIER, 1970, p.22)

Quando afirmamos que as representações de Abel - a infantil e a adulta (ou monstruosa) - se determinam mutuamente, queremos dizer que ao mesmo tempo em que escreve seu diário, Tiffauges passa por todo o processo de formação que o encaminha para o reconhecimento e realização de seu destino; logo, a representação que fará de si mesmo quando criança está também vinculada às interpretações e ressignificações que ele fizer. Este menino, que é uma versão de Abel enquanto personagem de si mesmo, é uma criança aberta a tudo, solitária e sensível ao comportamento do mundo diante de sua "esquisitice".

J'étais chétif et laid avec mes cheveux plats et noirs qui encadraient um visage bistre où il y avait de l'arabe et du gitan, mon corps gauche et osseux, mes mouvements fuyants et sans grâce (...) Mais surtout je devais avoir quelque trait fatal qui me désignait aux attaques même des plus lâches, aux coups même des plus faibles... (TOURNIER, 1970, p.23)

Insistimos até agora na artificialidade, no caráter fabricado da personalidade ogra de Abel, à revelia mesmo da própria personagem, que logo no começo de seus escritos afirma "je ne suis pas fou" (TOURNIER, 1970, p.23). Não se trata, na verdade, de pré-determinar que a personagem mente, ou delira, ou engana a si mesma, 
tampouco de aderir sem nenhuma desconfiança naquilo que o narrador conta. $O$ foco é ressaltar a importância da escrita para o estabelecimento de uma instância mítica na obra, pois ela não está dada, ela não é um pressuposto do leitor moderno. Se o mito perdeu o lugar privilegiado nas narrativas ficcionais, apenas com um esforço afirmativo e deliberado do narrador ele poderá retornar. A consistência da dimensão mítica, até agora sustentada apenas pela afirmação da existência de uma cisão na alma do protagonista, será devidamente posta à prova nesta pesquisa. E, se por um lado não aderimos a ela por completo, também não a recusamos definitivamente - sem essa suspensão temporária dos paradigmas e dos dados de realidade do leitor, é praticamente impossível levar a leitura deste romance a cabo.

\subsubsection{Manifestação do destino e hermenêutica}

Uma vez que Abel esteja convencido de quem é - uma criatura feérica - e do que deve fazer - cumprir seu destino, qualquer que seja ele - ele passa a buscar os "sinais" que lhe indicarão por qual caminho seguir. A leitura dessas pistas lhe fora ensinada por Nestor como uma ciência própria daquele que sabe seu lugar no mundo e nele pretende interferir. Trata-se de um conjunto de elementos cujas origens, em sua maioria, estão nas lembranças de Abel ou em suas formulações a respeito, e que se repetem sistematicamente ao longo de toda narrativa. Esses elementos compreendem um tipo de acervo de sinais, signos e conceitos que reforçam, por sua reincidência, as certezas de Tiffauges quanto ao destino - o seu e o do universo. 
É sobre esta reincidência dos sinais que interessa concentrar nossa atenção, pois ela faz parte da estrutura mítica do romance. Visitaremos a conceituação que Paul Ricœur deu ao símbolo e ao mito para, enfim, avançarmos na análise.

Há uma expressão segundo a qual o símbolo é "toute structure de signification où un sens direct, primaire, littéral, désigne par surcroît un autre sens indirect, secondaire, figuré, qui ne peut être appréhendé qu'à travers le premier" (RICCEUR 1969, p. 16), ou seja, o conceito está ligado sobretudo a uma função cognitiva, a uma transmissão de sentidos imediatamente apreensíveis e ainda outros que estão velados. Essa definição ainda não esclarece suficientemente a ligação do símbolo com possíveis estruturas míticas.

Em La symbolique du mal, o filósofo afirma que o símbolo está ligado ao fato da linguagem, pois embora a sacralidade seja percebida sobre o mundo, sobre os elementos e aspectos do mundo (sobre o céu, o sol, a lua, a água, a vegetação), ou seja, tenha uma base de concretude facilmente reconhecível, a manifestação do sagrado como "coisa" é uma matriz de significados simbólicos como palavra. É o mesmo que, segundo ele, dizer que o céu manifesta o sagrado e dizer que ele significa o alto, o imenso, o poderoso, a ordem, o imutável, o clarividente, o soberano. A manifestação do sagrado pela coisa é como a condensação de um discurso infinito, ou seja, manifestação e significação são duas coisas contemporâneas e recíprocas, a concreção da coisa é a contrapartida da sobredeterminação de um sentido inesgotável que se ramifica no cósmico, no ético e no político: "le symbole-chose est puissance d'innombrables symboles parlés qui en retour se nouent dans une manifestation singulière du cosmos" (RICCEUR 1960, p. 18). 
O símbolo permanece no estado de potência transcendente e latência cognitiva, como o estado bruto daquilo que, do sagrado, está acessível à leitura e entendimento (ou especulação) humanos. Em que divergem, então, o símbolo e o mito? Ricœur (1960, p. 23-25) explica que o mito é justamente uma espécie de símbolo arranjado e desenvolvido numa narrativa, em um tempo e espaço que não são coordenáveis àqueles da história e da geografia segundo os métodos críticos. 0 símbolo existe numa espécie de estado inato e latente do sagrado, e encontra no mito a redução da potência das incontáveis enunciações justamente porque fica circunscrito em uma formatação específica e corroborada por um grupo de enunciadores:

Par l'exemple l'exil est un symbole primaire de l'aliénation humaine, mais l'histoire de l'expulsion d'Adam et d'Ėve du Paradis est un récit mythique de second degré mettant en jeu des personnages, des lieux, un temps, des épisodes fabuleux; l'exil est un symbole primaire et non un mythe, parce que c'est un événement historique rendu analogiquement signifiant de l'aliénation humaine. (RICCEUR, 1960, p. 25)

Há um segundo ponto das idéias de Ricœur que é preciso retomar. A hermenêutica, amplamente estudada e problematizada em diversas obras do filósofo, serve a esta pesquisa naquilo que a relaciona com a compreensão dos símbolos e mitos. Isto é, quando afirma que sagrado pode ser lido nas coisas em que se manifesta, que o símbolo significa o sagrado, e que o mito é um símbolo reconfigurado em narrativa, Ricœur está aproximando a comunicabilidade da transcendência a uma questão de leitura e, portanto, de hermenêutica.

Com efeito, a definição de interpretação que ele oferece em Le conflit des interprétations é correlativa àquela do símbolo: "c'est le travail de pensée qui consiste à déchiffrer le sens caché dans le sens apparent, à déployer les niveaux de signification impliqués dans la signification littérale" (RICCEUR, 1969, p. 16). E, sendo 
assim, não há interpretação sem multiplicidade de significados, e apenas através da interpretação esses significados de fato aparecem.

Voltamos aos "Écrits Sinistres". O segundo passo da rememoração de Tiffauges é a recuperação dos "sinais" que lhe indicarão por que caminho seguir. A leitura dessas pistas Ihe fora ensinada por Nestor como uma ciência própria daquele que sabe seu lugar no mundo e nele pretende interferir. Trata-se de um conjunto de elementos cujas origens, em sua maioria, estão nas lembranças de Abel ou em suas formulações a respeito, e que se repetem sistematicamente ao longo de toda narrativa.

Ora, devemos sublinhar que o reconhecimento e compreensão dos sinais é, antes de tudo, uma faculdade cognitiva. A respeito de Nestor, Abel nos conta que "la grande affaire de sa vie... était le déchiffrement des signes" (TOURNIER, 1970, p. 36, grifo nosso), tarefa esta que Abel toma para si tão logo ele assume sua identidade feérica. Os "Écrits Sinistres", além de um exercício de recuperação mnemônica e reconfiguração da identidade de seu autor, são o espaço para que as lembranças recuperadas sejam lidas e interpretadas como sinais, todos estes elementos vão aos poucos constituindo um tipo de acervo de signos e conceitos que reforçam, por sua reincidência, as certezas de Tiffauges quanto ao destino - o seu e o do universo.

Há vários episódios no internato São Cristóvão que apontam para umas poucas imagens recorrentes, entre as quais a foria é a mais relevante. A palavra remete, de um modo geral, a um ato (carregar) e mais especificamente no romance, uma imagem (o adulto portador de uma criança). O conceito é relevante porque ele percorre todo o romance, em constantes atualizações e sempre em momentos 
chave no enredo. A imagem, que começa praticamente vazia de significado para o leitor, adquire ao longo do romance a dimensão mítica porque este é o processo pelo qual a palavra passa. A foria vai da latência e possibilidade de enunciações até sua cristalização em mito, incorporando a personagem Abel Tiffauges - a princípio externo ao símbolo - em sua versão final e mais poderosa do mito fórico, nas últimas páginas do romance.

Em resumo, os "Écrits Sinistres" desempenham um papel importante na narrativa, como instrumento e canal das etapas de recordação e subjetivação que lapidam a personagem principal, além de ser um exercício de leitura que Tiffauges faz com sua própria vida e pensamentos, depositando no diário um primeiro acervo de sinais que, à força de repetição, como veremos, estruturam o eixo temporal da obra.

Uma outra função ainda pode ser atribuída ao diário de Tiffauges: a aprendizagem dos sinais, o exercício de leitura que ele sustenta e viabiliza em Abel estende-se ao leitor. Pudemos observar que a predestinação surge na trajetória de Tiffauges como uma força alheia e incontornável, rapidamente aceita pela personagem. Ainda assim, a dinâmica do texto conta com a adesão do leitor para que ele participe da construção de seu sentido; isso é possível na medida em que, passadas as páginas dos "Écrits Sinistres", o leitor torna-se ele mesmo capaz de identificar e interpretar as ações do enredo como sinais do destino de Abel.

16 janvier 1938. [...] Sa face cachée, que je fus le seul à soupçonner, c'était les signes, le déchiffrement des signes. C'était là la grande affaire de sa vie, avec le despotisme absolu qu'il faisait peser sur tout Saint-Christophe. De quels signes s'agissait-il? Que révélait leur déchiffrement? Si je pouvais répondre à cette question, toute ma vie serait changée, et non seulement ma vie mais - j'ose l'écrire assuré que personne ne lira jamais ces lignes - le cours même de l'histoire. (TOURNIER, 1970, p.36) 
A Tiffauges cabe o primeiro levantamento e elaboração de suas memórias, ou seja, ele fornece o material primário que servirá a todo o resto da composição do romance. O leitor, por sua vez, é envolvido ativamente na narrativa quando coparticipa do ato de captação dos sinais e, partilhando dos mesmos pressupostos e métodos que Abel para ler o mundo, ele o lerá, e também transformará os símbolos em mitos, corroborando com a inevitabilidade do destino, com o efeito de verossimilhança do enredo e, portanto, com a estruturação do texto.

\subsubsection{Ação ritual e configuração mítica: o ato fórico}

Como dissemos, a foria, entre todos os símbolos que compõem a trama, é certamente a mais significativa. Interessa recuperar as diversas manifestações do conceito de foria para então analisarmos seu alcance e importância no romance.

A primeira representação da foria é de certa forma bastante simples; São Cristóvão carregando o menino Jesus de uma margem do rio à outra, cumprindo, como nos mostra o narrador, a sina de que seu nome é indício: Cristóvão é o Cristo+phoro, o porta Cristo. Sua simplicidade está na nobreza da intenção do homem, a travessia da criança de um lado a outro do rio pretende ser um gesto de bondade e subserviência e se torna, quando Cristóvão afinal percebe que "a criança pesava-lhe mais que o mundo inteiro", uma prova de entrega e sacrifício. O episódio de São Cristóvão e a travessia do menino Jesus foi revelado a Abel por intermédio de Nestor ainda no internato e, a partir deste momento, a imagem é constantemente 
reiterada na trajetória da personagem, ainda que distorcida e acrescida de outros elementos.

Quando o Rei dos Álamos ${ }^{6}$ surge, num ponto já mais avançado do enredo, cristalizase uma segunda representação do ato fórico na trama. Assim como o mito de São Cristóvão atravessando o rio, a figura do Rei dos Álamos pertence a uma lenda alemã, há muito tempo conhecida e transmitida entre as províncias nórdicas. A história conta que um rei atravessava um bosque a cavalo com seu filho quando um espectro de um homem, também a cavalo, começa a importunar o menino e tenta levá-lo consigo. O menino, apavorado, queixa-se ao pai, que não vê nem ouve o espectro, mas que tenta apressar a travessia do bosque para acalmar a criança, mas quando o rei se dá conta o menino está morto em seus braços. Esta lenda foi configurada por Goethe numa balada chamada Der Erlkönig, e inserida no romance através de uma tradução feita pelo próprio Tournier. Com efeito, a lenda do Rei dos Álamos não aparece na narrativa apenas através do poema, mas também em sua modalidade "oral" e folclórica, quando arqueólogos encontram dois corpos mumificados - o de um adulto e outro que pode ser de uma criança - no bosque de Walkenau.

\footnotetext{
${ }^{6}$ A tradução do francês "roi des aulnes" para o português "rei dos álamos", neste trabalho, está de acordo com a escolha feita pela tradutora Joana Morais Varela, da edição portuguesa de 1986 consultada. Ela explica em nota que após conversar com o tradutor de alemão Eugénio de Castro, responsável pela revisão do original de Goethe e da versão francesa do poema feita por Tournier, decidiu que a palavra "álamos", "embora botanicamente pouco correta, era literariamente mais adequada" (in TOURNIER, 1986, p. 281).

Ainda, é preciso mencionar que Erkönig é o nome de uma obra do compositor Franz Schubert inspirada no Der Erlkönig de Goethe. O título da peça, que é o mesmo do poema, geralmente é traduzido como "rei dos álamos", embora por vezes seja traduzido como "rei dos elfos". Sobre isso, o próprio Tournier se pronuncia em Le vent paraclet:

"Le plus étrange c'est qu'à l'origine de ce poème se trouve un erreur de traduction de Herder qui popularisa le folklore danois en Allemagne. Eller, les elfes, devint sous sa plume Erlen, les aulnes, parce que dans le dialecte qu'on parlait à Mohrungen en Prusse-Orientale, ville natale de Herder, l'aulne se disait Eller. Or il est peu probable que Goethe se fût intéressé à la légende du banal roi des Elfes. En revanche son imagination s'enflamma à l'évocation si précise et originale de l'aulne, parce que l'aulne est l'arbre noir et maléfique des eaux mortes, (...) elle évoque les plaines brumeuses et les terres mouvantes du Nord, et l'Erlkönig l'ogre aérien, amateur d'enfants, qui plane sur ces tristes contrées." (TOURNIER, 1977, p. 119)
} 
Assim, a notícia dos corpos encontrados torna-se, para Tiffauges e para o leitor, mais do que uma questão de arqueologia ou mesmo um reavivamento de um folclore local, embora tal seja a maneira com que o "mundo real" configurado na obra receba o fato. Reconhecemos logo uma segunda versão da foria que compreende uma imagem ainda mais forte e significativa para o romance.

A inserção da lenda de Erlkönig sedimenta e faz avançar o conceito de foria na obra. Sedimenta porque a figura do Rei dos Álamos encaixa-se perfeitamente no perfil do "agente fórico", considerando que ele carrega um garoto pela floresta. Contudo essa narrativa dentro da narrativa cria laços de intertextualidade e ressignificação que eliminam a transparência e a positividade que outrora fundamentaram o símbolo fórico, e nisso vemos o conceito avançar.

Se a história de São Cristóvão aponta para o cumprimento do dever e a consagração, o Rei dos Álamos por sua vez abre espaço para a instauração do sombrio, do fracasso, da perda. A travessia e a proteção do menino malograram-se, por mais que a isto o Rei tenha se dedicado, e assim o Rei dos Álamos, o espectro que ameaça e aniquila, reposiciona a foria como o gesto daquele que seduz e é seduzido, que carrega consigo e conduz à morte. Deste modo, torna-se complexa e ambígua a relação entre o portador e o infante, no momento em que os corpos são descobertos e a balada de Goethe lhes confere sentido específico dentro da estrutura lógica do romance, posto que ao símbolo vemos acrescida uma malignidade absoluta e inversa àquilo que São Cristóvão representa.

Tiffauges parece encontrar seu lugar entre um e outro, São Cristóvão e o Rei dos Álamos são afinal os extremos e os limites dentro dos quais a personagem age e avalia a si mesma. Isso porque o ato fórico não determina apenas um processo de ascensão de um símbolo a um mito, ele resvala num segundo conceito chave da 
obra tournieriana: a inversão. O papel que a foria desempenha no romance vai além de situar as margens metafísicas do Bem e do Mal, representadas, grosso modo, por São Cristóvão e pelo Rei dos Álamos respectivamente. É através da foria que Tournier engendra a noção de inversão maligna e inversão benigna e mantém, assim, os elementos e interpretações dos símbolos numa situação dinâmica. Em outras palavras, uma vez que as manifestações míticas já consolidadas do ato fórico - o Santo e o Espectro - opõem-se nitidamente no esquema de Bem e Mal, toda a trajetória de Tiffauges, em especial os momentos em que ele próprio participa dessa mise-en-scène que é a foria, oscila entre os extremos e portanto é ambígua, incerta, questionável, opaca, aberta.

A dimensão mítica do romance Le Roi des Aulnes, embora evidente, não é facilmente delimitável. Ela é detalhada, minuciosa, ela é construída ao longo das páginas e fundamentada nos símbolos que o autor elege. Segundo Arlette Bouloumié (1988, p. 7), “l'œuvre de Michel Tournier tire son originalité et sa profondeur de l'actualisation de grands mythes oubliés". Afirmar que o romance é mítico, entretanto, lança a leitura e as expectativas para além da coleta (e mesmo reformulação) de personagens e histórias ancestrais: afirmar a dimensão mitológica de uma obra implica em achar nela uma esfera absoluta, uma resposta - ou ao menos um esboço - a uma pergunta fundamental.

Temos já alguma pista de qual é essa pergunta quando analisamos a função da foria no romance e percebemos que ela circunscreve uma arena onde Bem e Mal devem confrontar-se. Eis o profícuo diálogo entre mito e metafísica, amplamente reconhecido na obra de Michel Tournier, e cujas engrenagens em Le Roi des Aulnes nos aponta o ato fórico. 
Assim, nossa leitura das manifestações da foria tende a aproximá-las, a tentar encontrar nelas a linha que indique e elucide os rumos da obra. Se é claro que Abel Tiffauges não adere por completo à santidade de São Cristóvão nem à vocação assassina do Rei dos Álamos - e por isso ele é um ogro tão particular - como entender as passagens em que ele protagoniza a experiência de "porte-enfant"? Com efeito, se este é um romance mitológico, se há nele um suporte mítico inquestionável, talvez seja correto supor que há elementos rituais no enredo, que funcionarão como roldanas de um sistema dinâmico maior. A foria, ou melhor, as experiências de foria pelas quais Abel passa configurariam justamente essas situações rituais, preparatórias, confirmadoras da trajetória da personagem; e não por acaso Abel é carregado por Nestor antes de ele mesmo se tornar um portador. Dentro de uma lógica ritualística, essa seria sua iniciação, necessária e inesquecível; seria o primeiro passo na formação de um ogro porta-infante.

Nestor, tendo carregado Abel em seus ombros por conta de uma brincadeira no intervalo das aulas, descarrega o pequeno amigo e permanece "un instant immobile, vaguement souriant, rêveur, avec une expression de bonheur que je ne lui avais jamais vue" e termina dizendo a Abel: "je ne savais pas, petit Fauges, que porter un enfant fût une chose si belle" (TOURNIER, 1970, p. 68). Esboça-se, desta maneira, o primeiro indício de que a foria proporciona ao portador uma sensação de júbilo, de fruição, de contentamento fora do comum. Ainda que Nestor tenha descoberto por acaso "a beleza de carregar uma criança", ele inicia Abel, com sua reação extasiada, num processo que apenas com os "Écrits Sinistres" Tiffauges se dará conta. Isso significa que Abel já é adulto quando carrega pela primeira vez uma criança. Trata-se de Jeannot, um menino que se machuca gravemente e que Abel socorre tão logo percebe o ferimento, tomando-o nos braços. O êxtase que sente, no 
entanto, é de tal maneira impactante que Tiffauges fica paralisado até que alguém o adverte sobre o estado do garoto. A esta sensação Abel só consegue responder de uma maneira, cumprindo uma espécie de ciclo ritualístico: "Je n’aurais jamais cru, parvins-je enfin à articuler, que porter un enfant fût une chose si belle!" e continua, inequívoco: "Cette simple phrase éveilla dans mon souvenir un long et profond écho". O eco de que Tiffauges fala em seu diário, evidente, é a voz de Nestor proferindo exatamente as mesmas palavras no momento em que ele experimentara a fruição do porte-enfant, o que consolida no romance o caráter ritualístico da foria. Mais ainda, por conta desse eco e dessa sensação, que interrompe uma fase particularmente depressiva, segundo nos conta a própria personagem, Tiffauges reavalia suas escolhas e orienta-se definitivamente para $o$ entendimento e cumprimento de seu destino.

A frase emprestada de Nestor é como uma chave, uma sentença de entrada que ratifica o júbilo do portador. E contudo, não é apenas ela que configura a foria como um ritual. A descrição que Abel faz de sua experiência menciona "cantos angelicais em sua glória", "ombros que tocam o céu", "perfume doce de rosas místicas", tudo, enfim, que associa a foria à suspensão da realidade mundana e a elevação máxima do espírito - ou, nos termos de Gagnebin (2006, p. 68), "um momento essencial de prazer ligado ao êxtase da dissolução dos limites do eu" (p. 68). A epifania ritualística justifica e compensa a existência ordinária, tão mais longa, árdua e rasteira. Ela se apresenta assim, como um átimo, um instante apenas - mas para o indivíduo a experiência desse átimo de sublimação se inscreve na eternidade.

"Puis vient enfin l'instant que j'attends en jubilant. Je laisse tomber mon rollei au bout de sa corroie, je passe mon bras droit sous les genoux du blessé, mon bras gauche sous ses aisselles, et je me relève avec mon frêle fardeau. Je me révèle, et mes épaules touchent le ciel, ma tête est environnée d'archanges musiciens qui chantent 
ma gloire. Les roses mystiques épanchent pour moi leur plus doux parfum. C'est la seconde fois en peu de mois que j'enlève dans mes bras un enfant blessé et que l'extase phorique m'enveloppe." (TOURNIER, 1970, p. 148)

Paul Ricœur (1960), ao abordar a constituição do rito, nos explica que a ação ritual e a fala mítica, tomadas conjuntamente, designariam um modelo, um arquétipo, que elas imitariam ou repetiriam. Ainda, ele afirma que imitação gestual e repetição verbal seriam tão somente as expressões estilhaçadas de uma participação vivida de um Ato original, que por sua vez seria o exemplar comum do rito e do mito. Nossa leitura da foria segue muito nesse sentido; ela desempenha, no romance, esse passo inequívoco em direção ao Adão original, estabelecendo com a Criatura última uma relação simbólica e significativa indelével. Em outras palavras, a foria acaba por se tornar ela mesma o mito fundador de Adão e, ao mesmo tempo, o ritual que pretende reestabelecer a condição eternamente perdida: o ato fórico é ele mesmo o arquétipo mítico e sua própria sombra.

É muito peculiar, para quem lê o romance, ter Abel Tiffauges como protagonista e narrador dos "Écrits Sinistres" porque há nele uma preocupação muito clara em traduzir suas experiências mais íntimas e intensas e, além disso, analisá-las minuciosamente. Tiffauges é uma personagem complexa - em sua configuração e trajetória - e um narrador detalhista, ensimesmado, reflexivo, culto. Ele se desdobra para documentar e racionalizar suas experiências espirituais, sem subtrair delas nenhuma fagulha de validade ou realidade; potencializando, assim, os aspectos míticos tanto quanto os romanescos da obra.

Em seu artigo, Jean-Bertrand Vray (in BOULOUMIÊ; GANDILLAC, 1990, p. 62) considera que o diário de Abel é sobretudo uma leitura delirante da Bíblia, leitura que ele efetua "através de seu desejo e sua perversão". Com efeito, Abel desde 
cedo coloca no horizonte do leitor suas interpretações da Gênese, de modo a reavaliar o sentido da Criação e esboçar uma verdade última: a primeira criatura, o "Adão original", era ao mesmo tempo homem e mulher.

\begin{abstract}
Alors quel ne devait pas être l'équipage de l'ancêtre fabuleux, homme porte-femme devenu de surcroît porte-enfant, chargé et surchargé. (...)

Car s'il y a dans la Genèse une chute de l'homme, ce n'est pas dans l'épisode de la pomme - qui marque une promotion au contraire, l'ascension à la connaissance du bien et du mal - mais dans cette dislocation qui brisa en trois l'Adam original, faisant choir de l'homme la femme, puis l'enfant (...)

Remonter la pente, restaurer l'Adam originel, le mariage n'a pas d'autre sens. Mais n'y a-t-il que cette solution dérisoire? (TOURNIER, 1970, p. 32)
\end{abstract}

O ato fórico a princípio se apresenta como uma resposta a esta questão tipicamente "tiffaugeana"; trata-se de um ritual de restauração, de reconfiguração da criatura, a realização do mito original. Dito de outro modo, se há alguma verdade na existência humana, se há uma origem à qual deve-se reportar e responder, ela - a verdade está no gesto preciso, na sagração da foria. Em seus "Écrits Sinistres", a reflexão de Tiffauges a respeito do êxtase que sentira com Jeannot em seus braços segue basicamente essa linha, e encerra com uma frase impactante, que Vray (in BOULOUMIÊ; GANDILLAC, 1990) classifica como uma "conclusão megalomaníaca":

Et là, je reviens nécessairement à mes méditations bibliques, à l'Adam archaïque d'avant la Chute, porte-femme et porte-enfant, perpétuellement en proie à une transe érotique - possédant-possédé - dont nos amours ordinaires ne sont que l'ombre pâle. Se pourrait-il que ma vocation surhumaine me fît accéder en de certaines circonstances à l'extase du grand ancêtre androgyne ? (TOURNIER, 1970, p. 114)

Em suma, temos que a foria é um símbolo, de acordo com a conceituação de Ricœur, que se solidifica e cristaliza ao longo do romance até configurar definitivamente um mito com a cena final de Abel carregando o pequeno Ephraïm; sabemos que ela se reitera na história pessoal de Abel depois de ser decantada de 
duas histórias bastante heterogêneas como a lenda de São Cristóvão e a balada do Rei dos Álamos. Ainda, consideramos que a foria orienta a trama na medida em que ela se presta como resposta à busca do personagem por uma verdade maior e fundamental, que se confunde, afinal, com a busca pelo seu destino.

Quando analisou a questão da origem, num colóquio destinado exclusivamente ao debate da obra de Michel Tournier, Jean-Bertrand Vray ponderou que na escritura de Tournier as reflexões filosófico-teológicas cumprem a função de alimentar a máquina romanesca. Em Le Roi des Aulnes, ele afirma, "la perversion est le développement d'une rationalisation forcenée, d'une logique et d'une cohérence à tout prix qui transforment en destin la vie du personnage" (in BOULOUMIÊ; GANDILLAC, 1990, p. 63). Essa leitura corrobora o que dissemos a respeito da dimensão mítica do projeto literário de Tournier; ele serve-se do mito e da filosofia como matéria-prima e os arranja, dentro de uma estrutura narrativa que em si configura aspectos míticos tanto quanto metafísicos. É a solidez dessa estrutura narrativa, justamente, que permite que elementos tão díspares mantenham contato e continuidade entre si, e deste modo Tournier fabrica as simetrias e antagonismos da trama.

Se podemos falar, enfim, em sementes nos "Écrits Sinistres", é certo que o olhar deverá ater-se ao ato fórico e à quantidade de elementos e funções que ele mobiliza para e no romance. Considerando que a foria aponta para a elaboração de um mito de origem interno e muito bem fundamentado na obra, e que o protagonista da narrativa não apenas busca por esse mito mas com ele se confunde, devemos enfim nos perguntar o que mais este símbolo pode nos dizer sobre a obra que já não esteja tão nítido na estrutura narrativa ou explicitado pelo próprio narrador. 
No diário, à passagem que contêm a "conclusão megalomaníaca" sobre a proximidade de Tiffauges com o "grande ancestral andrógino" seguem suas considerações a respeito da palavra euforia, que ele usa para descrever a sensação maravilhosa que sentira ao carregar uma criança:

6 octobre 1938. le premier mot qui se présente sous ma plume est apparemment banal et faible, mais il se révèle d'une grande ressource : l'euphorie. Oui, c'est une manière d'euphorie qui m'a enveloppé des pieds à la tête quand j'eus soulevé dans mes bras le corps inanimé de Jeannot. (...)

Sensation de bien-être dit platement le dictionnaire. Mais l'étymologie est plus instructive. II y a eu qui donne l'idée de bien, de bonheur, de joie calme et équilibrée. Et puis phorie qui dérive de $\varphi \circ \rho \varepsilon ́ \omega$, porter. L'euphorique est celui qui se porte avec bonheur, qui se porte bien. Mais il serait encore plus littéral de dire qu'il porte simplement avec bonheur. Et là, un trait de lumière illumine soudain mon passé, mon présent et, qui sait, mon avenir peut-être aussi. (TOURNIER, 1970, p. 113-114)

De maneira sucinta, o que afinal um mito de origem sugere é que há, ou houve, um estado inicial de existência. A configuração que Michel Tournier dá à foria coloca-a como uma espécie de meio termo, de artifício para que um indivíduo possa tocar, ao menos num instante, uma condição transcendente e sublime. $\mathrm{Na}$ esteira das reflexões de Tiffauges, e aceitando os dados etimológicos que ele oferece, temos que a experiência inicial da criação coincide com o estado de euforia, sendo "eu" a partícula designadora de felicidade e a "foria" o núcleo mínimo da fisiologia do Adão Original (andrógino, porte-femme e porte-enfant). Assim, o que um descendente de Adão pode fazer para recuperar a plenitude de outrora é cumprir o gesto da foria e obter disso o êxtase eufórico. Nas palavras de Ricœur:

Quelle est en effet la signification ultime de cette structure mythique? Elle désignerait, nous dit-on, l'accord intime de l'homme du culte et du mythe avec la totalité de l'être; elle signifierait une plénitude indivisible où le surnaturel, le naturel et le psychologique ne seraient pas encore scindés. (RICCEUR, 1960, p. 158) 
É no mínimo curioso que o júbilo mítico resultante de um ritual poderoso venha no bojo de uma ausência própria do corpo, de uma latência que chega muito perto da conotação sexual. A forma intensa com que esta euforia, "esta onda de beatitude" acomete o portador opõe-se, segundo o próprio Abel, à "sombra pálida que são nossos amores ordinários". Se há uma felicidade necessária e intrínseca à condição do portador, ela foi deixada de lado em sua forma original de maneira irreversível no momento em que Adão original se torna Adão e Eva.

De todo modo, o que nos interessa sublinhar é que a obra trabalha com uma plenitude corporal e emocional que foi perdida, que por sua vez desencadeou uma existência instável, reduzida, infeliz. A leitura de Le Roi des Aulnes pode ser atravessada por esta pergunta, afinal: o que há exatamente na experiência atual que não é feliz? A Queda do homem, nós sabemos, é tema recorrente na história da filosofia, da teologia e das artes. Entretanto, este é um romance cuja estrutura mítica mantém sua independência ficcional, e assim, importa-nos saber qual a relação desta pergunta com os demais elementos da narrativa. Sobretudo porque além da dimensão mítica, a obra possui uma dimensão histórica e crítica também muito delineada; certamente não se trata de coincidência que uma narrativa sobre a existência afórica, incompleta e errante esteja conjugada com a Shoah.

\subsubsection{Reiteração dos símbolos}

"les signes sont forts... les signes sont irritables" Abel Tiffauges

A maior dificuldade para a análise de um romance como Le Roi des Aulnes é a quantidade de detalhes e possibilidades de conexão entre os elementos. Michel 
Tournier é um escritor minucioso, de extremo cuidado com a rede que tece para sustentar sua narrativa. Esta parte do trabalho principia, então, com o reconhecimento da dificuldade, quiçá da impossibilidade, de esgotar cada reiteração de cada sinal que aparece aos olhos de Tiffauges e, por esta mesma razão, não pretendemos dar conta de todos, apenas identificar e situar os mais relevantes e evidentes entre eles.

O exercício de repère dos sinais visa dar sequência às formulações feitas até aqui, pois se os "Écrits Sinistres" gestam os símbolos que conduzem a narrativa, há que se mapear de que maneira se desenvolvem. Será menos um exercício de interpretação do que de análise e organização, mas é necessário porque nisto se concentra boa parte do processo de leitura e compreensão da obra. Como dissemos, o reconhecimento dos sinais potencializa a capacidade hermenêutica no livro porque atinge não apenas a personagem, que lê o mundo, mas o leitor, que aprende a identificar e lê-lo da mesma maneira, subjacente ao texto literário em si.

A reiteração dos símbolos em Le Roi des Aulnes estará, sempre, atrelada ao processo de inversão - inversão maligna e inversão benigna. Por ora, não nos interessa muito desenvolver e discutir o conceito com mais afinco, basta dizer que ele rege as reiterações e distorções de um elemento fundamental porque assume, na narrativa, uma função organizadora. Mais do que isso, a inversão nos mostra que todos os sinais são, de certa forma, contingentes, pois podem ser esvaziados de seu conteúdo e inseridos num contexto diferente, com um significado pelo menos inverso ao "original". 
Foria

A foria é claramente o primeiro e mais importante desses sinais que se repetem e convocam a trama com muita frequência, não é o caso de repetir tudo o que dela já se falou aqui a não ser que, embora profundamente ligada à trajetória de Tiffauges, a foria não the é exclusiva. Ela é reivindicada por Abel desde o princípio, ela vem de um Adão primordial, depois da lenda de São Cristóvão, passando pelo episódio com Nestor e pela lenda do Rei dos Álamos, mas sua dinâmica é muito menos linear.

A foria reaparece, por exemplo, nos cavalos - o "animal fórico por excelência" - que surgem na história, sobretudo nos bosques mágicos da Prússia Oriental por onde Abel se aventura. A foria também marcará uma das imagens mais fortes do romance, ocorrida na napola. Enquanto Tiffauges observa o treinamento militar a que as crianças são submetidas, ele as vê carregar as armas de combate:

La phorie qui définit l'idéal de la relation de l'adulte et enfant s'instaure monstrueusement entre l'enfant et le jouet adulte. Le joué n'est plus porté par l'enfant - traîné, poussé, culbuté, roulé, comme le veut sa vocation d'objet fictif, livré aux petites mains destructrices de l'enfant. C'est l'enfant qui est porté par le jouet englouti dans le char, enfermé dans l'habitacle de l'avion, prisonnier de la tourelle pivotante des mitrailleuses couplées.

Je touche ici pour la première fois à un phénomène sans doute capital, et qui est le bouleversement de la phorie par l'inversion maligne. (TOURNIER, 1970, p. 390)

Ou seja, a foria simplesmente se apresenta no mundo, ela não está limitada à ação de Tiffauges, tampouco ao ato de portar uma criança nos braços. Ela é antes um princípio, um modo de atuar sobre o mundo, e, sobretudo, uma chave de interpretação de um gesto. 
Duplos e simetrias

Assim como o ogro, o duplo constitui um dos grandes temas da obra tournieriana, determinando, por exemplo, a linha mestre do romance Les Méterores, protagonizado por gêmeos idênticos. Em Le Roi des Aulnes, o duplo toma proporções um pouco particulares e por vezes distorcidas. A gemelidade está presente num par de pombos idênticos que Abel captura enquanto trabalha para o columbófilo inglês, ainda no exército dos Aliados. Reaparecerá com os irmãos Haro e Haïo, filhos de um camponês da região de Kaltenborn, recrutados por Abel para entrar na napola.

Tiffauges s'en approcha avec curiosité, et tendit la main. Aussitôt l'œuf se dissocia et fit place à deux beaux pigeons couleur de feuilles mortes, parfaitement semblables. (...) Il les saisit tous deux à la fois et les examina en connaisseur, cherchant en vain un détail qui pût les distinguer l'un de l'autre. (TOURNIER, 1970, p. 196)

C'est ainsi qu'il avait repéré [...] un couple de jumeaux [...]. II avait toujours été fasciné par la gémellité qui lui paraissait receler un pouvoir vitale à une profondeur où la chair dicte sa loi à l'âme et l'asservit à ses caprices de la nature et livrait de gré ou de force à un être tous les secrets de l'intimité d'un autre être en faisant de lui son alter ego. A cela s'ajoutait que Haïo et Haro étaient roux comme des renardeaux, blancs comme du lait et piolés comme s'ils avaient été roulés dans le son. (TOURNIER, 1970, p. 381)

O duplo, na obra, não é constituído apenas por pares de gêmeos, mas pela simetria das formas e das combinações das coisas e dos seres que fascinam Abel. Eis o porquê de considerarmos como uma expressão do duplo a semelhança entre os pombos que Abel captura em Johannisburg e as crianças que recruta na Prússia Oriental. Assim como sua afeição era maior com o par de pombos gêmeos, um pombo prateado e robusto e ainda um pombo franzino a quem Tiffauges salvara a vida, seu afeto e atenção encontrará um conjunto de crianças que projetam 
exatamente essas características: o par de gêmeos, um garoto forte, de cabelos prateados e olhos cor de lilás, e finalmente, Éphraïm, o menino franzino que será salvo por Abel. (TOURNIER, 1970, p. 217-8, 224, 264-5).

O duplo, que pode ser metaforizado por um espelho na maioria das vezes, aqui encontra na projeção uma imagem mais condizente. Entre os pombos e os meninos há algumas similaridades quanto ao porte físico, e a similaridade se dá de um para um, cada ave corresponde a uma criança. Contudo, a força da projeção se exponencia porque além da identificação específica entre cada indivíduo do par, há a projeção da equação que eles, juntos, compõem. Cada elemento desse conjunto tem também uma referência externa que, por sua vez, determina outra identificação. Deste modo, o pombo e o menino robustos remetem a Nestor por conta de seu porte físico e tenacidade e formam com ele essa linha de reiteração imagética e simbólica. Por sua vez, a figura franzina e enjeitada - ora representados pelo pombo preto e por Éphraïm - é também uma projeção do próprio Abel quando criança, uma projeção de sua constituição física frágil e modos introspectivos.

No mesmo sentido, há entre Abel e Weidmann, o homem condenado à pena capital por homicídio na França, uma simetria assombrosa. Não apenas eles nasceram no mesmo dia, como possuem a mesma aparência, os mesmo tamanho e rostos idênticos. A semelhança, para que o leitor não pense ser forjada pela imaginação de Abel, é notada mesmo pela senhora que o acompanha: "mais monsieur Tiffauges. C'est qu'il vous ressemble! Ma parole, on dirait votre frère! Mais c'est vous, monsieur Tiffauges, c'est tout à fait vous!" (TOURNIER, 1970, p. 164). O assassino, sendo um homem completamente rejeitado pela comunidade e por ela considerado como um monstro, uma ameaça e um fardo, é apenas uma distorção do monstro feérico que Abel encarna. O sinal derradeiro que os une é a mão esquerda: a de Abel escreve, a 
de Weidmann mata (a mão canhota também estabelece um elo entre Abel e Hitler). Duas ações diferentes, mas que dentro da obra aproximam-se por sua natureza: quanto mais Abel escreve, mais sinistra e monstruosa se torna sua personalidade, mais solidificada se torna sua personalidade feérica e ogra. Tornar-se um ogro é dar um passo rumo à morte, a sua e a de outrem, é assumir o risco de conduzir a morte de alguém.

Num outro momento de sua trajetória, Abel será tomado pelo cadáver encontrado na mata de Walkenau (TOURNIER, 1970 p. 250), dada a semelhança do porte físico entre eles. Ao mesmo cadáver será atribuída a identidade lendária do rei dos álamos, ele mesmo constituindo um duplo: o rei que tenta salvar seu filho do reiespectro que tenta matá-lo.

Hibridismo homem-animal

Finalmente, há no livro diversas sugestões que aproximam os homens dos animais, e que fazem com que a imagem de um esteja refletida na do outro.

Abel identifica-se com um alce "semi-fabuloso" enquanto explora o bosque místico chamado Canadá, devido a algumas características físicas: "L'élan du Canada était aveugle. Dès lors Tiffauges comprit ce comportement quémateur, cette allure gauche, cette lenteur somnambulique, et, á cause de sa terrible myopie, il se sentit proche du géant ténébreux."(TOURNIER, 1970, p. 239)

Da mesma forma, quando Abel ganha do Oberforstmeister um cavalo enorme, ele não apenas sente uma profunda afeição pelo animal, mas como redescobre, de certa forma, sua própria identidade. A reconciliação de Abel com seu próprio corpo, 
provocada pela presença do cavalo a quem ele dará o nome de Barbe Bleue, indica a perfeita sintonia que caracteriza a dupla e a identificação que existe entre ambos.

Tiffauges prit possession de son cheval avec une émotion où les élans de son cœur solitaire se mêlaient au pressentiment des grandes choses qu'il accompliraient ensemble. (...) En vérité, frottant et lustrant la robe de sa monture, c'était les modestes satisfactions du cirage de ses brodequins et de ses bottes qu'il retrouvait, mais élevés à une puissance incomparable. Car si les pigeons du Rhin avaient été ses conquêtes, puis ses enfants chéris, c'était lui-même au fond qu'il pansait en consacrant tous ses soins à son cheval. Et ce fût pour lui une révélation que cette réconciliation avec lui-même, ce goût pour son propre corps, cette tendresse encore vague pour un homme appelé Abel Tiffauges qui lui venait. (TOURNIER, 1970, p. 299)

O marechal Göring ${ }^{7}$ também é incluído numa espécie de hibridismo metafórico com animais. O narrador usa os javalis da reserva de Rominten para assinalar a natureza grotesca e carniceira do militar nazista:

II affectionnait trop la grosse bête, courageuse, joviale et gloutonne, absorbant indifféremment céréales, insectes et charognes et qui le reposait par ses meurs désordonnés et imprévisibles des habitudes pédantes et minutieuses des cerfs et des chevreuils, attachés à leurs coulées, gagnages et reposées. (TOURNIER, 1970, p.268)

As crianças, como dissemos, são comparadas a pássaros, que, em não podendo carregar ninguém - e portanto não podendo constituir criaturas fóricas - simbolizam a liberdade e a elevação. Justamente, está na inocência infantil a chave da foria e da restituição do Adão original. No mais, é também significativo que três dos quatro pombos favoritos tenham sido mortos e comidos por um general, reproduzindo numa microdimensão o destino das quatro crianças que Abel ama: as três que pertenciam à napola morrem em combate, ou seja, aos olhos de Tiffauges, elas foram engolidas

\footnotetext{
${ }^{7}$ Sobre a personagem de Göring falaremos mais em "Göring, o ogro militar"
} 
pela guerra, pelo universo militar. Assim como apenas o pombo enjeitado se salva, Éphraïm também será o único a não perecer nas mãos dos generais ogros.

Essa comunhão entre homens e animais no romance mimetiza, na medida do possível, as criaturas fabulosas e mitológicas que emprestam aos animais a forma e as propriedades mais significativas. Eis que Tournier, sem inserir criaturas fisicamente híbridas em seu texto - o que descaracterizaria definitivamente a ambiguidade entre a as dimensões realísticas e mitológicas - elabora um meio de recriar os semi-humanos metaforicamente.

\section{Os espaços mágicos}

A trajetória de Abel não se desenvolve apenas numa esfera temporal, embora esta seja a esfera privilegiada no romance ${ }^{8}$. Procuraremos demonstrar ainda que oscilações entre história e mito, símbolo e escrita se dão necessariamente na manutenção e alteração do paradigma temporal. Ao espaço coube, portanto, um papel secundário e mais funcional, ele ajuda a pautar o alcance do universo mítico sob influência de alguma força sobrenatural. Em outras palavras, enquanto Abel passa por todas as experiências, as quais não obedecem a um clico temporal homogêneo, ele também atravessa diferentes espaços, saindo da França e passando pela fronteira com a Alemanha e atravessando o país, chegando à Prússia Oriental (Walkenau, Rominten, Kaltenborn) onde boa parte de sua história acontece e, afinal, onde ele "morre". São várias as considerações que ele faz em relação ao

\footnotetext{
${ }^{8}$ Como veremos em "A estrutura temporal",
} 
espaço em que se encontra, ao longo de sua trajetória. Vemos, por exemplo, a descrição que faz da França, terra detestada e menosprezada por ele:

\begin{abstract}
Moi si intolérant, si vite enflammé d'indignation quand j'étais en France, toujours maudissant et fulminant, je m'interroge parfois sur ma patience et ma docilité depuis que je foule le sol allemand. C'est que je me trouve ici constamment confronté à une réalité signifiante presque toujours claire et distincte, ou alors quand elle devient difficile à lire, c'est qu'elle s'approfondit et gagne en richesse ce qu'elle perd en évidence. La France me heurtait sans cesse par les manifestations blasphématoires élémentaires qui surgissaient dans un désert inexpressif. (TOURNIER, 1970, p. 348)
\end{abstract}

A Alemanha que ele encontra, todavia, é uma combinação complexa de espaços reais e espaços míticos, e geralmente é retratada como um espaço idílico, fértil, receptivo. Abel é tão afeito à idéia de migrar para o oriente que pouco que importa que a viagem seja feita num vagão de prisioneiros de guerra.

Tiffauges se laissa glisser dans la captivité sans résistance, avec la foi robuste et optimiste du voyageur qui s'y abandonne au repos de l'étape en sachant qu'il va s'éveiller quelques heures plus tard, en même temps que le soleil, lavé des fatigues de la veille, régénéré, prêt à un nouveau départ. II avait laissé tomber derrière lui comme vêtements souillés, comme chausses éculées, comme peaux craquelées, Paris et la France (...) II roulait maintenant vers le levant. On les avait entassés à raison de soixante hommes par wagon dans un train asthmatique qui s'arrêtait et manœuvrait à tout propos. (...) Tiffauges savait bien, lui, et il n'avait pas besoin de boussole pour cela, qu'on roulait vers la lumière. Ex Oriente Lux. De quelle lumière s'agissait-il ? II l'ignorait, mais il allait apprendre patiemment, jour après jour, avec de longues périodes d'obscurité hivernale et secrètement féconde, et des révélations d'un éblouissante soudaineté. (TOURNIER, 1970 p. 215 -216)

A intuição de Abel quanto ao rumo da viagem é um dos indícios do pertencimento entre ele e a terra prussiana, que se estabelecerá e fortalecerá em breve. As descrições minuciosas da flora dos bosques da região, a carga de significação e requinte que tudo adquire para Abel determinam o quanto aquele espaço está afinado com a natureza feérica da personagem. Podemos notar essa afinidade 
feérica entre o homem e a terra numa passagem em que ele, prisioneiro no campo, buscava um lugar em que pudesse defecar e sentir-se em paz:

Toute cette terre noire et grasse qu'il remuait jour après jour y était peut-être pour quelque chose: depuis son arrivée au camp, et malgré la nourriture chiche et médiocre, il vivait dans une grande béatitude fécale. (...) II avait tout loisir dès lors pour choisir le lieu propice où quelques coups de bêche et la mise en place de deux planchettes qui ne le quittaient pas édifiaient l'autel sur lequel il consommait son union intime et féconde avec la terre prussienne. (TOURNIER, 1970, p. 229)

Sendo um coprófilo, Abel relaciona a defecação com um estado de fruição pura, onde a corporeidade e a espiritualidade se equilibram e geram um bem-estar pleno. Ainda que seja irônico que o prazer resultante da "beatitude fecal" aconteça sempre em situações ligadas à violência, ou ao cerceamento de sua condição humana (aqui, por exemplo, ele é um prisioneiro de guerra), não podemos nos furtar a reconhecer a intensidade do vínculo que o personagem estabelece com a terra na qual se encontra. O uso do vocabulário matrimonial, sugerindo um "altar" onde a "íntima e fecunda união" será "consumada" cria um efeito extravagante e potente no leitor. A ligação de Tiffauges com o espaço é fisiológica, simbiótica, ambígua, ela atinge, pouco a pouco, dimensões sobrehumanas cada vez mais nítidas.

Essa espécie de bodas, ou de pacto, que ele estabelece com a terra, com cada elemento natural nativo, antecede via de regra um momento importante na trajetória da personagem. Nesse caso, guiando-se através de trilhas sutis e belas que parecem estar lá apenas para ele, Tiffauges chega ao Canadá, uma espécie de refúgio num bosque próximo ao campo de prisioneiros onde está o alce mágico Unhold e uma cabana. Nessa cabana, aliás, Tiffauges encontra um guarda florestal - o Oberforstmeister - que reconhece em Abel uma aptidão natural para cuidar de 
animais e por isso o leva do campo de prisioneiros para trabalhar na reserva de Rominten.

Algo parecido acontece em Rominten, região onde o marechal Göring estabeleceu sua reserva particular de caça. Göring, como dissemos, é uma personagem fortemente inspirada num militar que viveu e atuou na administração do Reich nazista: o marechal Hermann Göring ${ }^{9}$. E ele de fato dedicava-se à caça na reserva onde fizera construir seu chalé, em Rominten, na Prússia Oriental. O curioso é que a esta reserva que de fato existiu, corresponde uma descrição fantástica e surreal. Tiffauges, ao passar pelos portões de Rominten pela primeira vez, sente que

il pénétrait à l'intérieur d'un cercle féerique sous la conduite d'un magicien subalterne, reconnu cependant par les esprits du lieu. Le premier qui l'accueillit fut un grand lynx doré, assis sur une souche qui le regarda passer en riant dans ses minces moustaches de prince asiatique et en agitant les pinceaux de poils clairs qui surmontaient ses oreilles. Il fut ensuite escorté par un couple de castors, par un sacre blanc, et par un gros chien gris aux yeux bridés (...) mais c'était la flore - tantôt maléfique, tantôt bénéfique - dont les attaches avec les êtres féeriques étaient plus évidentes. (TOURNIER, 1970, p. 264)

Animais que o saúdam e cortejam, plantas e cogumelos que lhe indicam uma ligação com seres folclóricos. Tiffauges, de imediato, percebe que esta é uma terra completamente entregue a poderes sobrenaturais, de modo que sua intuição lhe dizia que estava prestes a submeter-se a uma "iniciation fantastique", e com surpresa Abel reconheceu que "s'il ne rencontra ni gnomes, ni princesse endormie, ni roi millénaire trônant dans le tronc creux d'un chêne, il fût bientôt conduit devant l'ogre de Rominten" (TOURNIER, 1970, p.265).

\footnotetext{
${ }^{9}$ Hermann Göring de fato existiu e foi um dos homens mais influentes no império nazista. A ele são atribuídas várias das ações mais violentas do III Reich, como a ordem para o massacre da noite dos cristais e subsequente perseguição aos judeus vitimados, a idealização dos campos de extermínio, entre outros. (SHIRER, 2008)
} 
A geografia configurada no romance, portanto, presta-se ao fortalecimento da instância mítica de modo geral e da caracterização da personagem de Abel, especificamente. Ela cria uma zona de conforto onde as inclinações fantásticas da personagem podem ser desenvolvidas sem comprometer a ambiguidade, a ironia ou o senso crítico da obra.

Não é preciso aprofundar-se muito para perceber que os símbolos engendram, na obra, uma espécie de mise en abîme, que já acontece aliás com tantas referências e histórias e digressões inseridas dentro da história principal. O jogo de simetrias, imagens, reiterações e distorções pode conduzir a incontáveis ligações entre os elementos, há sempre uma possibilidade de reconhecimento de um sinal, dada a minúcia com que a narrativa foi amarrada. Isso, naturalmente, pode conduzir a uma espécie de desânimo interpretativo, ou, pelo contrário, uma saturação do texto que vê todos os elementos reproduzidos infinitamente. A contingência dos sinais, que há pouco mencionamos, bem como a exaustiva reiteração, têm sua razão de ser, tudo se relaciona à constituição da personagem de Abel Tiffauges e a seu desenvolvimento na trama.

De todo modo, consideramos que os sinais do destino e da existência, embora integrantes de uma metodologia de leitura muito específica a Tiffauges, associada a uma concepção de vida e de mundo que também lhe é muito particular, estão de fato por toda parte no mundo; e se o texto nos dá a impressão de abundância e complexidade, se ele nos deixa com uma sensação de estranhamento, é porque o objetivo estético da obra foi plenamente alcançado. 


\subsection{Aspectos históricos da narrativa}

Se por um lado nos "Écrits Sinistres" o autor lança mão de diversas estratégias narrativas para solidificar a instância mítica em que a personagem se inscreve e na qual atuará ao longo de todo o romance, paralelamente ele constrói um conjunto de registros que acompanham os acontecimentos políticos da conturbada Europa às vésperas da Segunda Guerra, estabelecendo a interface entre a dimensão mítica e a histórica. Não é por acaso, certamente, que a datação do diário pessoal de Abel corresponda quase perfeitamente à agenda dos acontecimentos que determinaram a ascensão e a consolidação do Terceiro Reich, ou, muito além disso, que os escritos de Abel apontem também para uma reação a cada um desses eventos.

Os anos de 38 e 39 , sabemos todos, foram intensos e redefiniram a posição da Alemanha não apenas no cenário político europeu, mas mundial. Hitler, conforme nos conta William Shirer (2008a), inaugura uma modalidade de conflito para o qual a diplomacia das potências não estavam preparadas e assim, se projeta como a grande personalidade de sua época, igualmente temido e respeitado. Tornou-se claro, naquele fim de década, que o alcance de seu plano para consagrar o império nazista extrapolava os aspectos da vida econômica e cultural da Alemanha, ou seja, Hitler procurou configurar uma trajetória de conquistas na qual a transformação da vida cotidiana era apenas um ponto de partida.

No romance, a fabulação permite que o narrador mimetize a sensação da ameaça, pautado indiretamente pelo o olhar do historiador que agora se volta e reconhece, sobretudo na movimentação desses dois anos específicos, os sinais inequívocos do totalitarismo e do massacre por vir. É assim, a princípio, que a esfera fantástica, essencialmente fictícia e intimista do romance se conjuga a uma dimensão mais 
próxima da referência histórica, da realidade, com todas as ressalvas a esta palavra, literariamente configurada.

Ora, se os "Écrits Sinistres" lançam na obra os sinais que a orientarão e determinarão os rumos da trama, é porque, de maneira análoga, o narrador entende que os anos que antecederam a guerra determinaram seus rumos. E afinal, se há uma linha condutora da ascensão do Terceiro Reich, se ele apenas foi levado a sua radicalidade porque o mundo se recusou a perceber em tempo suas inclinações, dentro dos limites ficcionais caberá a Abel captar e colecionar cada uma das pistas do colapso humano que se aproxima. Disso decorre a ligação indissociável entre a personagem e a história, os sinais do destino de Abel são também sinais do destino humano e, em última análise, são sinais historicamente recuperados num exercício de elaboração por parte do autor.

\subsubsection{Incorporação de fatos históricos}

A questão da origem de Abel Tiffauges, assim, excepcionalmente mítica e misteriosa, encontra nos elementos históricos uma justificativa bastante pragmática, pois é pautada por uma temporalidade contingente, mundana, circunscrita. $O$ passado de Abel, seja em sua instância mais recente ou a mais remota, como vimos, são construções mnemônicas e discursivas que visam garantir a indefinição temporal, e portanto a atemporalidade da personagem. Sem anular essa proposição, a dimensão histórica se projeta sobre este ponto e nos indica que, paradoxalmente, a atemporalidade de Abel implica na sua ligação necessária com os tempos do préguerra, isto é, quanto mais Tiffauges é destituído de uma história objetiva e clara, 
mais preso à temporalidade de seu diário ele fica. O presente da sua formação, ou melhor, o presente da formação de sua monstruosidade, de sua personalidade ogra, coincide com o presente da ascensão do regime nazista, e de certa forma é determinado por ele. Sendo uma criatura mágica e sobrehumana, Tiffauges dialeticamente atua como testemunha histórica da Segunda Guerra; e nesse jogo de projeções a narrativa literária se constrói.

Sob esse aspecto, é bastante irônico que o primeiro texto dos "Écrits Sinistres" seja a respeito da eternidade de Tiffauges pois esse registro, sendo datado, deixa à mostra seu caráter efêmero - para dizer o mínimo, pois além da ironia, essa contradição também expõe a fragilidade da transcendência. No mais, ele fixa necessariamente um princípio para a configuração histórica, estabelecendo que à revelia da natureza e da ascendência mitológica da personagem, sua participação no mundo humano começa em 3 de janeiro de 1938; de modo que suas ações, ainda que visem a sublimação e o divino, possuem raízes fincadas na contingência histórica.

A partir daí, todas as idéias e lembranças de Abel podem ser submetidas à leitura que identifica nelas uma alegoria, ou ao menos uma metáfora, da Europa naquela época. Em especial quando Tiffauges escreve, em 6 de janeiro, que "tout est signe, mais il faut une lumière ou un cri éclatants pour percer notre myopie ou notre surdité" (TOURNIER, 1970, p. 15). Os sinais, verdadeiros alicerces da narrativa em seu eixo transcendental, já se apresentam como importantes agentes na constituição histórica; os sinais que passaram despercebidos ao mundo são aqueles que conduzem toda a trajetória de Tiffauges no romance, mas também são os rastros que Hitler deixou durante sua empresa. A inclinação quase inata de Abel à 
decifração dos signos é o contraponto da vocação de Hitler em espalhá-los, em fazê-los ressoar através de todo o território sob seu jugo, de modo que a guerra que ele provoca é também uma "guerra de sinais", como mais tarde Tiffauges definiu, é uma guerra que pretende içar a suástica e impor a interpretação nazista da história e da mitologia, das raças, dos povos, dos modos de vida.

Apesar disso, não consideramos que os "Écrits Sinistres" pretendam representar, no sentido da mímese artística, a trajetória da guerra. Antes, parece-nos que sua especificidade está na fissura entre as duas instâncias, isto é, o diário de Abel não se presta a registrar metaforicamente a história assim como não ousa ignorá-la como se fosse a manifestação intelectual de um ser mitológico. Os escritos de Tiffauges, além de estabelecerem balizas temporais através de seu formato e balizas metafísicas através de seu conteúdo, parecem ser especialmente a manifestação possível, no nível emocional e intelectual, de uma personalidade que está aberta e atenta aos conflitos de seu tempo. Não se trata, portanto, de fixar a leitura do diário na esteira da mitologia ou da historiografia, fazendo dele um material de segunda mão para a compreensão do mundo. A pluralidade das referências mantém o texto e a leitura num horizonte sempre mais amplo, mais flexível, mais interessante.

Enfim, a monstruosidade de Abel se desenvolve e toma consciência de si no decorrer dos meses de janeiro e fevereiro, o que corresponde ao estabelecimento da campanha nazista na Áustria e o início das pressões diplomáticas sobre as democracias ocidentais. No dia 2, por exemplo, Tiffauges conta que sentiu uma "étrange présence" (TOURNIER, 1970, p. 41, grifo do autor) enquanto manuseava um elástico com os dedos, e menciona, no dia 16, a cisão que a dupla escrita - a 
destra e a canhota - provoca em sua personalidade. Esses pequenos sinais parecem encontrar no dia 18 alguma uniformidade, quando Tiffauges diz:

Et moi, caché parmi les assis, faux sédentaire, faux bien-pensant, je ne bouge pas certes, mais j'entretiens et je répare cet instrument par excellence de la migration, l'automobile. Et je prends patience parce que je sais qu'un jour viendra où le ciel, lassé des crimes des sédentaires, fera pleuvoir le feu sur leurs têtes. Ils seront alors, comme Caïn, jetés pêle-mêle sur les routes, fuyant éperdument leurs villes maudites et la terre qui se refuse à les nourrir. Et moi, Abel, seul souriant et comblé, je déploierai les grandes ailes que je tenais cachées sous ma défroque de garagiste, et frappant du pied leurs crânes enténébrés, je m'envolerai dans les étoiles. (TOURNIER, 1970, p. 51)

A implicações da diferença entre sedentários e nômades nós procuramos determinar melhor em "Variações do mito adâmico e do mito platônico". Por ora, basta explicar que essa diferença se baseia na interpretação que Abel faz da Gênese, de modo a separar os seres nômades, descendentes de Adão, dos seres sedentários, descentes de Eva. Como Adão gostava de correr, caçar e explorar, a gestação não Ihe era conveniente. Eva, por outro lado, gostava de permanecer sob a sombra das árvores, tinha uma atitude mais contemplativa e pacata. A "descendência" dos povos não é constituída, evidentemente, por questões biológicas, mas pelas inclinações e atitudes das pessoas de modo geral. Abel, que prefere viajar a ficar na França e por isso entende a si mesmo como um "falso sedentário", refere-se aos povos nômades - os judeus e os ciganos - perseguidos pelos sedentários - os alemães nazistas. Interessa observar que Abel profetiza pela primeira vez um massacre, a dois dias do discurso em que Hitler declarou ao mundo que o Reich se ocuparia "da questão" dos alemães e sudetos que habitavam na Áustria e na Tchecoslováquia e a seis dias de uma grande depredação da cidade de Viena - em especial os estabelecimentos de judeus - por parte dos nazistas austríacos (SHIRER, 2008a). Embora o personagem não tivesse mencionado a guerra nem qualquer uma das figuras que 
protagonizavam o cenário político da época, e portanto não se possa inferir que ele sabia exatamente o que estava acontecendo, Abel demonstra simplesmente uma afinação precisa com o "curso natural das coisas", para usar uma expressão sua. E mesmo que sua formulação sobre a cena apocalíptica final não esteja plenamente conformada com o que de fato se passará - sobretudo porque Abel ainda não passou pela experiência epifânica da foria - ela será retomada muitas outras vezes, sempre em tom profético e delirante, e cada vez mais próxima de sua exata configuração final.

Em março, enquanto a autonomia da Áustria parece cada vez mais insustentável diante do Führer que a todo custo quer subjugar o país e vingar-se das frustrações de sua juventude, Tiffauges escreve a respeito da história de Adrets, contada anos atrás por Nestor: trata-se de um homem que observa outro cair de um penhasco enquanto se debatia com o urso que o atacara. Adrets, que nada fez para ajudar, responde, quando indagado, que não conseguira impedir a queda porque estava maravilhado com o que via: "je ne savais pas qu'un homme qui tombe fût une chose si belle" (TOURNIER, 1970, p. 71). Ao desfecho misterioso da história Abel, acrescenta uma outra reflexão de Nestor:

Il y a une vérité humaine - j'allais écrire nestorienne - qui passe infiniment celle des faits. Après m'avoir raconté la vie ténébreuse du baron des Adrets, Nestor n'ajouta aucun commentaire. Mais je ne puis m'empêcher aujourd'hui de rapprocher de ce récit une réflexion qu'il exprima plus tard et que je ne compris pas sur le moment. II avait dit : "II n'y a rien sans doute rien de plus émouvant dans une vie d'homme que la découverte fortuite de la perversion à laquelle il est doué ». (TOURNIER, 1970, p. 71) 
A frase supostamente proferida por Adrets, é claro, é recuperada por Nestor quando ele carrega $\left.A b e\right|^{10}$, e depois retomada pelo próprio Tiffauges numa situação análoga. A reiteração dessa fala, neste contexto, faz referência ao próprio processo de autodescoberta, da tomada de consciência que coloca uma pessoa diante de uma perversão da qual ela não consegue se desvencilhar facilmente. É claro que a perversão de Abel é a foria, assim como a decifração dos signos era a perversão ou uma das perversões - de Nestor (Abel dirá a certa altura que "la décifration était sa chose", referindo-se ao amigo). Extrapolando os limites da subjetividade de Abel, e tentando encontrar no contexto em que ele se insere uma referência que caiba nesta passagem, é pertinente pensar, mais uma vez, que ele sugere um modelo de interpretação para a experiência de Hitler diante de suas perversões, sua obsessão pela cidade que outrora o humilhou.

As negociações entre líderes de Estado, as ameaças veladas, as intenções e crimes disfarçados mesmo em discursos e promessas falsas, todos estes elementos compunham uma espécie de guerra política, vigente na época, que encontra no diário uma formulação frustrante:

Chaque jour nous serrons des mains qui ont étranglé ou versé de l'arsenic. Des affaires dont s'occupe la justice sont par définition déjà des échecs puisqu'elles n'ont pas su demeurer inaperçues. (...)

En vérité notre société a la justice qu'elle mérite. Celle que correspond au culte des assassins qui fleurit à la lettre à chaque coin de rue, sur les plaques bleues où sont proposés à l'administration publique les noms des hommes de guerre les plus illustres, c'est-à-dire des tueurs professionnels les plus sanguinaires de notre histoire. (TOURNIER, 1970, p. 72)

\footnotetext{
10 "je ne savais pas, petit Fauges, que porter un enfant fut une chose si belle" (TOURNIER, 1970, p.68). Abordada em "Variações do mito adâmico e do mito platônico".
} 
A partir de março de 1938, Abel começa a fazer algumas observações esporádicas a respeito da política como campo de atuação dos piores homens. Sua desconfiança irremediável quanto às instituições de modo geral e aos políticos europeus em particular o fazem declarar-se anarquista mais de uma vez ao longo do romance. Com efeito, o que parece angustiar a personagem é o uso deliberado da máquina estatal para a supressão das vidas e o desvirtuamento da alma humana. Abel, que em breve se tornará um crítico insistente da malignidade inerente ao regime nazista, desde os tempos em que trabalha como mecânico em Porte-des-Ternes já demonstra um desprezo mordaz pelo governo francês - desprezo aliás que se acentua, por exemplo, com o caso da execução de Weidmann.

Em abril, a questão da expansão do modelo de governo e de vida dos nazistas já começa a figurar diretamente na obra, mesmo que de maneira esporádica, irritando profundamente o protagonista por conta da proposição "antes canhões que manteiga", efetivamente usada por Hitler (SHIRER, 2008a) para motivar a produção bélica na Alemanha. Sobre isso, Tiffauges escreve uma nota curta, datada do dia 4, dizendo que "la formule 'plutôt des canons que du beurre'. C'est sous sa forme la plus basse l'expression de la grande inversion maligne partout en œuvre. (...) Cela veut dire en termes nobles, en termes ordinaires : plutôt la mort que la vie, plutôt la haine que l'amour" (TOURNIER, 1970, p. 91).

Shirer (2008a) conta detalhadamente como Hitler e seus generais sufocaram o plebiscito que o governo austríaco tentou organizar em março a fim de descobrir se o povo desejava de fato pertencer ao Terceiro Reich. Uma vez que as resistências do chanceler Schuschnigg foram quebradas e sua administração entrou em colapso, os grupos nazistas organizados cuidaram de promover intensamente a ideologia do partido nacional-socialista dentro do país. Quando a ocupação alemã já estava 
devidamente ajambrada, ao menos aparentemente, o plebiscito foi realizado em 10 de abril da maneira mais fraudulenta e opressora possível; e com $99,75 \%$ de votos favoráveis, o povo austríaco "optou" pela anexação.

\begin{abstract}
Dessa forma, a Áustria, como tal, por um instante, passou para a margem da história, tendo seu próprio nome suprimido pelo vingativo austríaco que agora a unira com a Alemanha. (...) $\mathrm{O}$ antigo andarilho austríaco convertido em ditador riscara sua terra natal do mapa e despojara imediatamente a brilhante capital de sua última auréola de glória e de importância. A desilusão entre os austríacos era inevitável.

Durante as primeiras semanas, a conduta dos nazistas em Viena foi pior que qualquer outra vista na Alemanha. Havia uma orgia de sadismo. Dia após dia, grande número de judeus, homens e mulheres, eram vistos esfregando os signos de Schuschnigg dos passeios e limpando as sarjetas. Enquanto trabalhavam com suas mãos e de joelhos, com as tropas de assalto escarnecendo deles, turbas se juntavam para insultá-los. (SHIRER, 2008a, p. 467)
\end{abstract}

Este episódio projeta-se no romance da seguinte maneira:

11 avril 1938. 99,06\% des électeurs autrichiens se sont prononcés hier en faveur d'un rattachement de leur pays à l'Allemagne. Cette ruée presque unanime à l'abîme n'est pas l'effet d'une force extérieure qui balaierait toutes les résistances. Non, le mal est enraciné en chacun, et la foule placée devant l'alternative vie-mort crie «la mort! la mort!» comme les Juifs répondaient à Ponce Pilate "Barabbas! Barabbas! » (TOURNIER, 1970, p. 94)

Dois fatores que provavelmente participaram da elaboração deste episódio em nível autoral não poderiam ser comprovados nesta análise. O primeiro deles são as informações a que Tournier teve acesso; é possível que ele tenha lido uma versão diferente da que Shirer propõe para o resultado "quase unânime" do plebiscito. O segundo é a intencionalidade do autor em fazer seu protagonista culpar diretamente os austríacos pela anexação, ou por certa leniência em relação ao nazismo.

De todo jeito, esses episódios diretamente dedicados aos assuntos políticos contemporâneos mostram que toda a movimentação do império nazista, mesmo em 
seus detalhes, não escapou à configuração da narrativa, pelo contrário, ela foi absorvida e mesmo interpretada, e constitui, inclusive, o primeiro eixo da dimensão histórica do romance. Isso significa que há um equilíbrio no desenvolvimento das camadas cognitivas da obra, pois mito e história correm subjacentes e paralelos num mesmo texto. Para desvendar seus mecanismos e características é preciso então procurar os elementos estruturais e os fatores intertextuais que orientam a configuração mítica e a histórica, ou seja, os sinais que delineiam a estrutura mítica e as informações, explícitas ou não, sobre o contexto político e cultural no qual o romance se insere.

Toda a agenda do Führer e de seu império pauta, por exemplo, o ritmo de abandono e retomada do diário por parte da personagem. Assim, a lacuna que existe nos "Écrits Sinistres" entre maio e outubro de 1938 corresponde ao prazo dado por Hitler para a total colaboração da Tchecoslováquia na questão dos Sudetos. Em maio, enquanto a Tchecoslováquia tenta com todas as forças resistir às pressões do governo alemão e convencer França e Inglaterra a cumprirem suas promessas de cooperação e proteção, Abel faz longas considerações a respeito da civilização moderna, e não esconde seu ódio por toda a hierarquia de poder e pelos métodos diplomáticos que só fazem mascarar os conflitos. A natureza de seus escritos é claramente oposta a toda ideologia nazista:

Il faut que tu songes à une Constitution sinistre (...) 1 - la sainteté est le fait de l'individu solitaire et sans pouvoir temporel. 2 - inversement le pouvoir politique relève intégralement de Mammon. Ceux qui l'exercent prennent sur eux toute l'iniquité du corps social, tous les crimes qui sont commis chaque jour en son nom. C'est pourquoi l'homme plus criminel d'une nation est celui qui occupe la position la plus élevée dans la hiérarchie politique : le Président de la République et, après lui, tous les ministres, et après eux tous les dignitaires du corps social (...)" (TOURNIER, 1970, p. 105) 
Quando, em outubro, ele retoma seus "Écrits Sinistres", explica que estava tomado de "ennui de vivre" e o que lhe faz recuperar o ânimo é a experiência da foria, que já abordamos. No Terceiro Reich, essa época corresponde à vitória das investidas e manipulações de Hitler sobre a Tchecoslováquia, de modo que os alemães entram num estado de pleno entusiasmo, orgulhosos dos feitos políticos de seu alto chanceler. Não significa que neste ponto a euforia de Abel esteja em consonância com o regozijo dos alemães, evidentemente; mas que se mantém num grau notável o paralelismo entre Tiffauges e os acontecimentos históricos, sobretudo os que marcam a trajetória de Hitler enquanto líder político e, por conseguinte, enquanto personagem da narrativa.

\subsubsection{Os limites da expressão}

Veremos, quando abordarmos a configuração do mal no romance, que há pelo menos duas fontes de malignidade bem identificadas; uma delas é de natureza sobrenatural, nomeada como Satan ou Mammon, que conduz os mecanismos de inversão e influencia o curso dos acontecimentos da pior maneira possível. A outra é especificamente humana, e se deixa transparecer sobretudo nas decisões que as pessoas tomam sem prestar atenção ou considerar o que lhes está sendo oferecido (como é o caso do plebiscito austríaco) e, assim, o mal humano está associado, na obra como na teologia judaico-cristã, à liberdade de escolha.

Por ora nos ocuparemos apenas das questões que envolvem a contextualização da malignidade, qualquer que seja sua fonte ou essência, nos "Écrits Sinistes". Na 
verdade, não interessa exatamente a expressão do mal, mas as manifestações que construam uma historicidade na obra e implementem uma linguagem para referir-se ao nazismo e à Shoah. Se com facilidade encontramos críticas diretas e indiretas ao militarismo e à política, assim como aos preceitos nazistas de honra, raça, trabalho e comunidade, todas as datas referentes a massacres e atos de violência direta estão ligadas a textos que indicam forte introspecção, ou servem-se de uma linguagem onírica, delirante e bastante enigmática.

É o caso do texto de 20 de outubro do diário, no qual Tiffauges narra ter passado a noite insone e ter andando pelas ruas de Paris: "como o céu estava doce e luminoso, eu me lancei ao acaso das ruas conduzindo minha velha Hotchkiss", passando por um "dilúvio de legumes e frutas" e sentindo-lhes os aromas e os sabores todos. A abundância o faz pensar nas refeições grandiosas de Gargantua mas de sua parte, não consegue sentir apetite porque "a abundância ridiculariza toda idéia de consumo, desencoraja a gulodice" (TOURNIER, 1970, p. 115, tradução nossa). Não apenas a cena que ele descreve é delirante, ou indica um estado de sonolência que torna difusa a realidade, mas a linguagem empregada para narrar é suntuosa, sinestésica, lírica:

Mais les portefaix, les forts de la ville, retiennent toute mon attention en raison de l'affinité que je ressens entre eux et moi. leur large dos, leurs main énormes, cette démarche rapide à petits pas qu'ils adoptent quand ils vont, coiffés d'un petit demibœuf ou d'une caque d'harengs, tout cela, c'est moi bien sûr, d'un certain coté. Mais c'est une phorie trivialisée, abaissé à des utilités mercantiles et subalternes. Et sans doute est-ce pourquoi on écrit grossièrement forts des Halles, au lieu de phores des Halles. Le fort est la forme vulgaire du phore. Et j'imagine aussitôt un vrai phore des Halles, superbe et généreux, portant triomphalement sur ses épaules formidables une corne d'abondance qui vomit à ses pieds un inépuisable trésor de fleurs, de fruits et de pierres précieuses. (TOURNIER, 1970, p. 116) 
Embora a data de 20 de outubro não remeta especificamente a algum fato histórico, podemos entender que esse trecho dos "Écrits Sinistres" refira-se a uma época de genuíno fortalecimento do Terceiro Reich, de modo geral. Todo o passeio de Abel pela cidade abarrotada de alimentos, cheiros e cores é também uma travessia entre o real e o onírico que permanece indeterminada para o leitor. Com efeito, tomados em conjunto, os textos de Tiffauges mostram facilmente a alternância entre a expressão do ódio mais profundo contra aqueles que massacram pessoas, a expressão da euforia religiosa mais límpida e extasiante e, ainda, a expressão de um estado melancólico, deprimido e mesmo delirante.

Que os escritos sinistros estão atrelados ao calendário sombrio dos acontecimentos que culminaram na Segunda Guerra e na Shoah, parece já bem estabelecido; e se é assim, eles compreendem um subtexto que aponta para a não aceitação da realidade histórica, para a inconformidade de Abel diante de eventos que Ihe escapam por completo. Nessa passagem de 20 de outubro, aliás, ele parece tentar elaborar o mal-estar que sente individualmente e coordenar uma espécie de reconstrução onírica de uma vida coletiva e abundante na cidade.

Uma outra passagem é muito significativa: a de 10 de novembro.

A noite de 9 de novembro de 1938 ficou historicamente conhecida como a "noite dos cristais", ou a "noite dos vidros quebrados" (SHIRER, 2008a), por causa das atitudes criminosas orquestradas pelo diretor do Serviço de Segurança nazista contra os judeus. Usando a morte de um secretário da embaixada alemã em Paris, provocada por um jovem judeu cujo pai tinha sido enviado a um campo de concentração, grupos de alemães supostamente civis quebraram, incendiaram, mataram, agrediram, estupraram. A partir dessa noite, a condição dos judeus alemães piorou 
consideravelmente, sua humilhação e exclusão da sociedade chegou a um ponto irreversível e absurdo.

Em 10 de novembro Tiffauges escreve uma passagem curta, falando sobre as dificuldades de dormir e a sensação de angústia:

10 novembre 1938. Toute la nuit, l'angélique m'a fait suffoquer et m'a obsédé de rêves de noyade et d'ensevelissement sous le sable, sous la terre, dans la boue... Je me lève, la poitrine toujours broyée, mais heureux d'en finir avec ces fantasmes qui grossissent une réalité déjà suffisamment revêche. Café amer au point de n'être pas buvable. Un grand brame. Deux grands brames. Aucun soulagement. (TOURNIER, 1970, p. 124)

O sonho de Abel é a tradução do horror. O afogado, o enterrado vivo na areia, na terra, na lama, todas as imagens de seu pesadelo apontam para a aniquilação, para a inviabilidade da existência e da morte mais dolorosa. $O$ ataque covarde contra os alemães judeus, feito no meio da madrugada, é a própria terra natal que se volta contra os indivíduos e os engole, os quer destruir. Não há conforto possível quando as pessoas são arrancadas de suas camas e jogadas à rua, enquanto seus rastros são destruídos; e a intranquilidade da noite de Abel corresponde simbolicamente à experiência de horror à qual as vítimas foram submetidas.

Abel continua seu relato e diz que "la seule consolation de la matinée est d'ordre fécal. (...) je regarde attendri ce beau poupon dodu de limon que je viens d'enfanter, et je reprends goût à la vie". É curioso, e um pouco consternador até, que o espaço do contentamento da alma de Abel, que por vezes é preenchido pelo êxtase mais absoluto, tenha se retraído e limitado à expressão mais mínima da vida, do corpo. A escatologia, que pode remeter mesmo ao fim último da humanidade na Terra, referese aqui a um processo de despejo e de evacuação, e de tal maneira se estabelece a 
projeção entre o massacre dos judeus e a defecação de Tiffauges que ele emprega o verbo "enfanter", correspondente francês a "parir", para descrever as fezes.

A bizarrice da alegria coprófila de Abel elabora ironicamente o profundo pessimismo que atravessa essa passagem: "heureux d'en finir avec ces fantasmes qui grossissent une realité déjà suffisamment revêche" e "ce dont l'homme prend le plus mal son parti, c'est d'être un sac d'excrément à deux pattes".

O que mais aproxima esses dois excertos dos "Écrits Sinistres", afinal, é que ambos desprendem-se um pouco do discurso metafísico habitual de Abel, ainda que aproveitando alguns elementos peculiares de seu acervo discursivo, para propor um desconforto irreversível que atinge tanto a experiência real quanto a onírica. Diante da violência mais aguda, a realidade torna-se paradoxalmente inviável aos indivíduos lúcidos e atentos a seu próprio tempo, e se já não é mais possível lidar diretamente com ela, tampouco o universo onírico poderá oferecer conforto ou alívio. No limite de sua capacidade, a linguagem oferece um espaço de manobra, onde, enfim, o indivíduo organiza como pode suas formulações e tenta dar sentido a uma experiência que se mostra radicalmente tortuosa e inaceitável.

Os textos selecionados deixam à mostra as fissuras por onde o desespero e a intranquilidade da personagem escapam, e nos indicam que certas experiências não encontram uma expressão justa, nem adequada, nem suficiente. Assim, Abel Tiffauges, narrador de si mesmo e narrador de seu destino, devorador de sinais e profundamente ligado à ordem primeira das coisas, se converte temporariamente numa personagem historicamente situada e que percebe que a existência humana já não pode encontrar sua plenitude - a não ser sob embriaguez religiosa, alcoólica ou amorosa, como diz (TOURNIER, 1970). 
A limitação da expressividade, em última análise, não se projeta nesses excertos sob a forma de um discurso truncado ou descontínuo, mas na ausência de referência direta aos fatos da Shoah, combinados de imagens que remetem à frustração e à angústia. No mais, em seu bojo vem sugerido, mais ou menos sutilmente, o pessimismo que marcou toda a época da Segunda Guerra; e talvez seja uma grande ironia do romance que a personagem mais entusiasmada com a dimensão divina e transcendente guarde no fundo da alma um desespero irremediável, isto é, que a entrega apaixonada de Abel ao seu destino também seja uma maneira de elaborar a ruína da alma humana e negar a existência tal qual ela se mostra. 


\section{CONFIGURAÇÕES DO MAL}

O sublime não designa mais o elã para o inefável. Jeanne Marie Gagnebin

\subsection{Paul Ricœur e a investigação do mal humano}

É praticamente inevitável, àqueles que se prestam a estudar mitologias, deparar-se com sistemas de símbolos e narrativas que abordem a questão do mal em alguma instância e, mais especificamente, o mal de que sofrem os homens. Quando redige a proposta dos dois volumes Finitude et Culpabilité, Paul Ricœur (1960) deixa bem claro que este será seu campo de investigação: os mitos cuja estrutura e simbologia concernem a experiência do mal humano.

De certo modo, a análise do mal também se apresenta incontornável aos leitores do romance Le Roi des Aulnes, óbvia e imediatamente pela figuração da Shoah na trama, mas também porque o herói, como toda trajetória na qual ele é inserido, sustenta uma série de perversões e transgressões que colocam em xeque as noções de inocência, malícia, agressão, cura. A violência permeia a obra em modalidades muito variadas, ainda que sua configuração seja nada convencional e aparentemente amenizada. Para que a violência, e por conseguinte o Mal maiúsculo, absoluto, metafísico - da obra sejam devidamente estudados, importanos fazer um desvio para inserir algumas das formulações de Ricœur a respeito do assunto. 


\subsubsection{A narrativa do Mal, o mal na narrativa: tipologia}

$\mathrm{Na}$ introdução, apresentamos uma formulação segundo a qual os mitos, não em sua totalidade mas em sua maioria, surgem como uma tentativa de resposta ou abarcamento de uma experiência de falta. Não há dúvidas de que eles constituem a primeira tentativa de conhecimento e compreensão da experiência da vida, de estar no mundo, de ser e ser assim, ou seja, os mitos surgem como um campo legítimo de logos.

No entanto, é sabido também que o mito não resistiu ao advento do pensamento filosófico moderno e que as ciências, uma a uma, cuidaram de subtrair-Ihe o campo de atuação. Deste modo, nos diz Ricœur (1960, p.154), "le mythe ne peut plus être coordonné aux lieux de notre géographie, nous sommes tentés de nous livrer à une radicale démythologisation de toute notre pensée." Esta "desmitologização", intimamente ligada à separação entre a História como saber específico constituído e independente do mito conduz, ironicamente, à possibilidade de recuperação do mito em si, da captação do mito enquanto mito e, portanto, da conquista, pela primeira vez na história da cultura, da dimensão mítica (RICCEUR, 1960).

Com isso, Ricœur propõe um olhar sobre as mitologias que abdique de um "faux savoir" imediato e as recupere em sua capacidade simbólica pura, em sua vocação latente e poderosa de significar e revelar. Para tanto, é preciso descolar o mito de sua função etiológica inicial, isto é, a explicação que deles advém, a fórmula causal fixa e necessária que eles pretendem transmitir como verdade deve ser colocada de lado para que enfim o pensamento filosófico possa recuperar uma dimensão do conhecimento genuinamente mítico. Então o mito não pode ser exatamente uma história que aconteceu num espaço e num tempo determinados, para que não se 
confunda com o saber histórico, tampouco pode ser uma resposta transparente a um "por que" metafísico:

Le départage de la rationalité et de son mime est en effet aussi décisif que celui de I'histoire et du mythe ; il en est même le fondement : car l'histoire n'est histoire que parce que sa recherche des " causes " s'adosse à l'Epistémè des géomètres et des physiciens, lors même qu'elle s'en distingue. [...]

Mais peut-être y a-t-il une manière de répéter le mythe comme mythe, en deçà de son glissement à la gnose, dans la nudité et la pauvreté d'un symbole qui ne serait pas une explication mais une ouverture et une découverte. Tout notre effort va donc tendre à dissocier mythe et gnose. (RICCEUR, 1960, p. 156)

É de fato importante que o esforço do crítico em desvencilhar mito e logos esteja previamente estabelecido pois se é verdade que o mito em si é uma tentação e um convite à gnose, a questão do mal parece potencializar a facilidade com que mito se torna uma explicação metafísica. Se há algo que desde os primórdios o homem é capaz de perceber, se há um consenso entre comunidades e gerações as mais diferentes possíveis, é de que a existência humana é marcada pelo sofrimento e pela possibilidade do mal, do mais incompreensível e aterrador mal. Ricœur assinala, inclusive, que o mal não apenas representa a mais considerável provocação ao pensamento como também oferece um sorrateiro convite ao irracional (RICCEUR, 1960, p. 157).

O mal intermedia de maneira insuportável a contradição vivida entre a destinação do homem, projetada coletivamente na imaginação da inocência original e de perfeição final, e a situação efetiva do homem, reconhecida e confessada. Diante das representações míticas mais sublimadas e transcendentais, a experiência terrena frustra-se radicalmente e o homem vê surgir "um gigantesco 'por quê?'”(RICCEUR, 1960, p.155) no centro de sua existência. 
Seguindo ainda o percurso que Paul Ricœur estabelece na parte sobre a função simbólica dos mitos, chegamos à sua proposição mais importante: a questão é identificar o ponto preciso da atuação do símbolo, ou melhor, da narrativa que ele configura. Por não ser uma explicação nem uma história precisamente datada e localizada, isto é, por não carregar consigo pistas evidentes o bastante para que os homens possam deduzir logicamente alguma verdade ontológica, resta ao mito ser uma narrativa - e nisso já insistimos bastante neste trabalho - que, simbolicamente, "abra e descubra uma dimensão da experiência que, sem a narrativa mítica, permaneceria fechada e dissimulada" (RICCEUR, 1960, p.157).

Cada comunidade, evidentemente, desenvolve e elege suas narrativas míticas a respeito da origem do mal humano de acordo com suas idiossincrasias. Em seu estudo, Ricœur procura identificar e tipificar os sistemas maiores de configuração mitológica do mal para estabelecer uma análise comparativa.

A partir disso o filósofo decanta duas modalidades de mito de "commencement", que resumiremos da seguinte maneira: um deles está relacionado ao caos pré-criação, geralmente oriundo de culturas politeístas que tenham configurado pra si uma espécie de teogonia. Assim, a criação do cosmos vem de um Drama, de um conjunto de ações, muitas vezes violentas entre as divindades, em que há deuses vencedores e deuses vencidos. O mal, nessas culturas, relaciona-se quase sempre ao confronto e ao caos dos tempos anteriores à criação do homem, e nele - nesse caos - está contido um "antigo sistema" em que a ordem não existia e a vida não era viável. Anterior e alheio ao homem, o mal ainda ameaça retornar porque, sendo Drama, a criação é um processo em aberto, mítico, cíclico e a história decorrente dela será uma repetição das origens. O caráter inacabado da criação e a 
consequente estrutura circular e reiterada nos interessa sobremaneira - e veremos adiante por quê.

Em um segundo sistema mitológico, a criação do cosmos não é oriunda de um conflito anterior entre deuses, até porque não há sequer uma teogonia que torne possível e propício qualquer disputa e caos. Neste caso, toda a existência origina-se num ato de fala, na Palavra, e portanto ela é fechada, ou seja, encerrada no momento específico da enunciação divina. Não há caos original, nem Drama fundador, não há malignidade necessária prévia ao homem. Nesses termos, somos levados a crer que a existência é primária e necessariamente positiva, plena e perfeita. Mais ainda, que a criação que inaugura a existência, inaugura também a História. Ora, o mal e a falta são constatações vividas, como dissemos, e se ela não é anterior ao homem pode ser apenas contemporâneo a ele, ou melhor: decorrente. Em uma mitologia que credita ao homem primordial a pureza de toda a criação divina, que faz dele parte de um projeto intrinsecamente bom e inocente, o mal só pode existir num momento em que esse homem falha, num lugar e tempo determinados.

Et c'est l'Histoire qui est Drame, non la Création. Ainsi le Mal et l'Histoire sont contemporains ; ni le Mal ni l'Histoire ne peuvent plus être rapportés à quelque désordre originaire ; le mal devient scandaleux en même temps qu'il devient historique. (RICCEUR, 1960, p. 192)

A constatação da contemporaneidade do Mal e da História nos mostra também que há outros agentes e determinantes no Drama que constitui a criação, e que na esteira desse drama há uma complexificação da condição humana tanto quanto da possibilidade de redenção e salvação. Ricœur afirma que "si le mal est coextensif à l'origine des choses, à titre de chaos primitif et lute théogonique, il doit en résulter 
que l'élimination du mal et des méchants appartient à l'acte créateur comme tel' (1960, p. 180-181). Em outras palavras, a contrapartida ao drama do caos teogônico

é o ritual cultural específico de mímese da instauração do mundo (e portanto da instauração da vida e do sentido), e assim os homens encontram o desenlace e a superação da precariedade da existência.

Diferentemente, o Drama da criação não oferece reconciliação entre o homem e a existência através de um ritual mimético. Com efeito, a condição humana após a Queda tende a ser irrevogavelmente problemática e o Salut torna-se um evento histórico, preciso, único, com a grandeza e potência original da criação propriamente dita - e por conseguinte, do Mal.

\subsubsection{O mito adâmico}

Toda a reflexão a respeito do mito adâmico vem, naturalmente, na esteira da análise do mito da criação. Paul Ricœur é bastante cuidadoso em esclarecer que o conceito de mito adâmico não dá conta necessariamente de toda referência a uma figura humana primordial, posto que muitas mitologias contam com um homem arquetípico e primevo sem contudo atribuir-Ihe as características específicas de que Adão é exemplar.

O mito de Adão, considerado por Ricœur "antropológico por excelência" (1960, p. 218), conserva em si uma intenção nitidamente etiológica, sobre a qual falaremos mais adiante. A princípio, o que nos interessa sublinhar é que a constatação do alcance antropológico do mito adâmico passa por uma linha de análise que se sustenta, basicamente, em três considerações, ou traços, relevantes. 
Em primeiro lugar, Ricœur procura refutar a imagem mesma de "queda" ponderando que o mito adâmico se refere, antes de mais nada, a um ancestral humano cuja condição é homogênea à nossa. Sendo assim, se há uma perfeição prévia e absoluta que o faz beirar a divindade, ou pelo menos a sobre-humanidade, ela nada mais é do que uma projeção que procura remodelar o mito adâmico e fazê-lo se conformar com a imagem de queda. Em outros termos, Ricœur rejeita que o mito de Adão seja a história de uma subtração na condição humana, de uma queda espiritual, moral ou essencial - ele defende que a passagem da condição humana designa a falta essencial, ou o écart (1960, p.219). A perfeição da criatura anterior à queda seria, portanto, o advento de uma interpretação e roupagem específicas, promovidas muito depois da redação do texto bíblico, do mito adâmico genuíno.

O segundo aspecto do mito adâmico é que ele desdobra as origens do bem e do mal, distinguindo com bastante clareza a origem radical do mal e o estado anterior e original de bem de que gozavam os seres criados por Deus. Eis aí, nos explica Ricœur, o ponto essencial ao caráter antropológico do mito: ele posiciona o homem como fonte, como começo do mal no seio de uma criação que lhe é anterior e superior, isto é, uma criação cujas origens estão no ato de absoluta e suprema bondade de Deus. O surgimento do mal está ligado a uma passagem, ele é precisamente um evento que separa um antes e um depois e configura, assim, a estrutura humana de maneira tal que nela já esteja latente a capacidade de falha e de malignidade, mesmo quando seu estado era o de inocência original: "le mythe adamique raconte comme un événement le passage de l'innocence au péché en tant que statut d'un homme destiné au bien et enclin au mal' (1960, p. 220)

Finalmente, o terceiro aspecto do mito adâmico - e talvez o mais relevante a este trabalho - consiste em situar as outras figuras que se apresentam e se submetem 
ao homem primordial. Se Adão é o homem "destinado ao bem e inclinado ao mal", nas palavras exatas do autor, a serpente encarna sem nenhuma ambiguidade o mal completo, a alteridade, o adversário, ela ocupa um espaço que logo em seguida será ocupado pelo diabo, enfim, a serpente é ela mesma o mal cujas origens nós não sabemos ao certo quais são. Há ainda Eva, que Ricœur posiciona em sua leitura como uma espécie de interlocutora, ela é a personagem que efetivamente atua diante e em conjunto com a alteridade que a serpente figura. Essas duas figuras, enfatiza Paul Ricœur, estão submetidas à figura central e protagonista de Adão, ainda que elas mesmas se desenvolvam e dialoguem com outros símbolos do mal.

Tomando-o tão somente como mito, Ricœur exclui de sua abordagem qualquer possibilidade de compreensão de Adão como um relato real, histórico, das origens humanas e da origem do mal. A observação pode nos parecer demasiado cautelosa e evidente, mas ela tem sua razão de ser e Ricœur argumenta que houve muito sofrimento na história da cristandade justamente por causa de uma interpretação literal deste mito. Como mito, Adão deve ser entendido exclusivamente como uma configuração de símbolos que apontam para uma experiência anterior e impulsionante do relato, a saber, a tomada de consciência do homem judeu da universalidade do mal. No mais, é precisamente o caráter simbólico do mito que reside a investigação do autor: "L'histoire de la 'chute' n'est qu'un mythe, c'est-à-dire moins qu'une histoire; mais: l'histoire de la chute a la grandeur du mythe, c'est-à-dire a plus de sens qu'une histoire vraie. Mais quel sens ?' (1960, p.222).

Esse sentido que o mito carrega e mantém latente Ricœur defende que esteja relacionado a uma especulação a respeito do poder da imperfeição e da liberdade humana. Ora, o mito adâmico traz a tona uma das questões filosóficas mais caras à 
cultura ocidental: a possibilidade de escolha, a liberdade para agir, tão profundamente humana. Assim, Adão não passa apenas de um estado de inocência a outro de falibilidade e pecado, ele também pode ser compreendido como a passagem do não filosófico ao filosófico, à incrustação do homem na sua condição mais feliz e ao mesmo tempo mais dilaceradora: a liberdade.

Assim, continua Ricœur, "le symbole donne a penser" (1960, p.222), ele é sobretudo uma questão de reflexão e conhecimento, de auto-conhecimento. $O$ autor sustenta que há esse poder exploratório e heurístico do mito, mas que ele só pode ser descolado de uma função explicativa, causal, do mal humano, se compreendido como recuperação de símbolos fundamentais elaborados na experiência viva da mácula, do pecado e da culpabilidade (1960, p. 222).

Ora, essa experiência viva de culpabilidade é a chave mesma da antropologização do mal, posto que o monoteísmo hebreu rejeitou qualquer possibilidade de teogonia ou de uma figuração divina essencialmente má. Pondo de lado as narrativas de luta, crime, adultério entre divindades e semi-divindades, pondo de lado inclusive uma personalidade maldosa e trágica do deus criador, a ética monoteísta elege uma natureza humana que se presta perfeitamente ao papel de berço do mal. Condição humana, mal humano. Eis a chave da leitura de Ricœur sobre o mito adâmico:

C'est le fruit de l'accusation prophétique dirigée contre l'homme: la même théologie qui innocente Dieu accuse l'homme ; or cette accusation, de plus en plus intégrée et assimilée à la prise de conscience de l'homme juif s'est muée en un esprit de pénitence (...) qui découvrait ainsi au delà des actes, une racine mauvaise à la fois individuelle et collective, tel un choix que chacun ferait pour tous et tous pour chacun (RICCEUR, 1960, p. 225-6).

É nessa passagem que, enfim, Ricœur formula a universalidade do mito adâmico, não apenas metafisicamente, colocando na alma humana a capacidade essencial de 
agir e falhar, mas historicamente, generalizando a toda comunidade judaica a experiência da perda do paraíso. Ainda, o autor insere este mito definitivamente em seu sistema de análise estrutural que prevê, de maneira sucinta, as seguintes funções (RICCEUR, 1960, p. 154):

1. O mito deve englobar a humanidade em seu conjunto em uma história exemplar, radicalizando a experiência individual, posto que ela só é possível se "o homem" (o herói, o protagonista) servir de paradigma a todos os homens - em suas ações, virtudes e falhas.

2. A universalidade do homem manifestada pelo mito deve circunscrever um movimento, a saber, de seu Começo a seu Fim, ou seja, a trajetória pela qual o homem saiu de um estado de perdição e encontra a redenção.

3. O mito deve responder a pergunta fundamental: como foi possível ao homem sair do estado original de inocência e condição de criatura e chegar à atual, culpado, pecador, maculado?

A primeira e a terceira características nos parecem mais cristalinas, resta agora retomar as formulações que mostram como exatamente funciona a segunda. Ela se refere à trajetória pela qual a humanidade em toda sua história, ela se refere a uma linha mestra, um ponto de apoio que orienta a comunidade em direção à sua própria profecia. Ricœur se refere a este aspecto como pertencente ao "reino da escatologia" (RICCEUR, 1960, p. 190), na medida em que ele se ocupa dos fins últimos dos homens e do mundo. Esse fim, é preciso lembrar, se apresenta com as mesmas dimensões e potencialidades míticas que constituem o mito da criação, e por isso o mito do Juízo Final, desde sempre e para sempre, é ambivalente: ele traz 
a promessa de recuperação do paraíso e de perdão ao mesmo tempo que ameaça condenar as falhas e banir eternamente os pecadores.

Le mythe proto-historique servit ainsi non seulement à généraliser l'expérience d'Israël à l'humanité de tous les temps et tous les lieux, mais à étendre à celle-ci la grande tension de la condamnation et de la miséricorde que les prophètes avaient enseigné à discerner dans le propre destin d'Israël. (RICCEUR, 1960, p.227)

Assim, uma vez que as origens do homem e de sua condição estão estabelecidos, uma vez que ele tem ao alcance uma representação simbólica poderosa que Ihe revela que o mal faz parte de sua própria alma, o sentido último da redenção, e portando da vida como um todo, está dado. Deparamo-nos, sem surpresas, com as bases da teologia judaico-cristã.

\subsection{Confluências entre Le Roi des Aulnes e a Simbólica do Mal}

As formulações de Paul Ricœur a respeito do mito, e em especial sua leitura do mito adâmico, oferecem um suporte bastante rico para a análise de Le Roi des Aulnes. Desde muito cedo no romance percebemos o chão sobre o qual ele é erigido; é o mesmo chão em que Ricœur pisa quando estuda a simbologia dos mitos do mal: o substrato religioso judaico-cristão analisado à luz de uma racionalidade que desconfia da mensagem imediata dos mitos e que trabalha portanto visando uma compreensão filosófica maior, ou distinta, do sentido latente das histórias primordiais. 


\title{
3.2.1. Variações do mito adâmico e do mito platônico
}

Estruturalmente, o que aproxima a narrativa de Tournier do mito adâmico de Ricœur é precisamente o fato da existência de Adão, o momento em que Deus molda o humano e Ihe comunica o sentido de sua existência: crescei e multiplicai. A partir disso, a interpretação distorcida que Abel oferece a respeito da corporeidade e sexualidade do primeiro homem confere certa independência ao mito e, como vimos, sua radicalização conduzirá aspectos importantes da trama. Para que possamos analisá-lo, eis o excerto em que Tiffauges recupera e interpreta o ponto alto da Criação:

\begin{abstract}
Quand on lit le début de la Genèse, on est alerté par une contradiction flagrante qui défigure ce texte vénérable. Dieu créa l'homme à son image, il le créa à l'image de Dieu, il les créa mâle et femelle. Et Dieu les bénit, et il leur dit: "Soyez féconds, croissez, multipliez, remplissez la terre et soumettez-la... " Ce soudain passage du singulier au pluriel est proprement inintelligible, d'autant plus que la création et la femme à partir d'une côte d'Adam n'intervient que beaucoup plus tard, que chapitre II de la Genèse. Tout s'éclaire au contraire si l'on maintient le singulier dans la phrase que je cite. Dieu créa l'homme à son image, c'est-à-dire mâle et femelle à la fois. Il lui dit : "Crois, multiplie ", etc. Plus tard, il constate que la solitude impliquée par l'hermaphroditisme n'est pas bonne. II plonge Adam dans le sommeil, il lui retire, non une côte, mais son " côté ", son flanc, c'est-à-dire ses parties sexuelles féminines dont il fait un être indépendant. (TOURNIER, 1970, p. 31)
\end{abstract}

Se é consolidado que o eixo mítico da narrativa é a Gênese bíblica e a figura de Adão, ainda que distorcido e reinterpretado, devemos nos ocupar um pouco da figuração divina no romance. Pouco se fala de Deus propriamente dito, seja direta ou indiretamente, e talvez isso de deva a uma intenção do autor em conservar na obra certo teor antropológico, centrando a dimensão mítica do romance nas origens e no destino humano, e naquilo que no homem toca o transcendente. Em outras 
palavras, é plausível considerar que Le Roi des Aulnes se fundamenta numa versão particular do mito adâmico não apenas porque o texto faz uma referência explícita a esta "personagem", mas porque em sua estrutura, ele também aponta para o homem quando se propõe a discutir o mal e a condição humana.

O mal, aliás, é um conceito que ainda não situamos exatamente, mas sobre o qual já é possível afirmar que nada na obra nos leva a entender que seja oriundo de um conflito teogônico ou de uma determinação divina. Sendo assim, a relação que vemos entre mito, história e malignidade, em Le Roi des Aulnes, compartilha em grande medida com o que desenvolvemos anteriormente: a história é consequência dos rumos que o homem tomou depois de sua criação, depois de rompida a camada de seu estado inicial.

A dimensão história do romance inegavelmente aponta para a fraqueza e a contingência humanas, e ainda que haja um destino, ele não é motivado ou determinado por nenhum tipo de divindade. Com efeito, Abel faz menções a um Deus em diversas passagens, indicando uma entidade divina de acordo com o paradigma judaico-cristão. Sua existência, no entanto, está sempre atrelada à função criadora do mundo, e portanto fixada no passado remoto da humanidade, nos tempos pré-históricos. O Deus de quem Abel fala nunca chega a se tornar, no romance, um ser com consciência e vontade específicos quanto ao destino de Abel e da humanidade. Desta maneira, uma divindade que não se revela, que abdica de qualquer volição ou influência sobre sua criação pode ser considerada, para certo efeito, nula dentro da estrutura narrativa mítica interna ao romance - o que reforça, um pouco mais, o caráter antropológico do mal. 
Afirmamos, há pouco, que Michel Tournier distorce o mito adâmico e assim the confere maior independência em relação ao paradigma religioso do primeiro homem. Com efeito, o que o escritor faz é sobrepor ao mito bíblico um mito da tradição filosófica grega, a saber, extraído de um diálogo de Platão. Tournier conhece muito bem o mito do andrógino de $O$ Banquete, como mostra um artigo seu intitulado Des éclairs dans la nuit du cœur do qual transcrevemos um excerto:

\begin{abstract}
Au commencement, l'homme était double, nous apprend le Banquet de Platon. Il était double : quatre bras, quatre jambes, deux visages - mais une seule tête - deux sexes. II était rond comme une boule, comme un astre, procédant de la Lune, de la Terre ou du Soleil, selon le cas. Car ce sexe double pouvait revêtir trois formes: double-femelle, mixte, double-mâle. (...)

Voici qu'il entreprit d'escalader le ciel pour conquérir l'Olympe! Zeus aurait pu l'anéantir comme il avait fait auparavant des géants, eux aussi en révolte contre lui. II s'en garda, ayant eu une meilleure idée: celle de couper en deux cet être aventureux. Ainsi fut fait, avec le concours du chirurgien-esthéticien Apollon qui fût chargé de rendre figure humaine au grand mutilé.

Depuis cet horrible attentat, chaque moitié d'homme gémit après son complément. Le trouve-t-elle, les deux demi-portions s'accolent passionnément avec des pleurs et de désespoir, secrètement convaincues que tous leurs transports ne reconstitueront pas l'être primitif de jadis. Ainsi s'expliquent les trois types de couples qu'on observe aujourd'hui : les couples mâles procédant du Soleil, couples de femelles placés sous le signe e la Lune, couples mixtes qui relèvent de la Terre. (TOURNIER "avantpropos " In: TRÉMOIS, Y. Mythologies, Ed. Michèle Broutta, 1970, apud BOULOUMIÊ, 1988, p. 150)
\end{abstract}

Arlette Bouloumié observa que Tournier respeita o caráter cosmogônico do mito platônico insistindo na completude do andrógino original, símbolo da perfeição e ligado à filiação com os astros. Mas que inverte o texto original colocando os casais femininos sob o signo da lua e os casais heterossexuais ligados à Terra, pois em Platão é justamente o contrário. Bouloumié argumenta que, assim, Tournier sublinha a banalidade dos amores heterossexuais. A ruptura inicial não apenas faz do andrógino uma vítima de seu próprio orgulho, ela nos interessa porque dá conta de uma função etiológica: explicar o sofrimento dos amantes pois o amor traduz não a 
procura do prazer ou a procriação, mas a busca nostálgica - e fadada ao fracasso da unidade perdida (BOULOUMIÊ, 1988).

Em Le Roi des Aulnes o autor funde ambos os mitos - o bíblico e o platônico - para desenvolver uma terceira mitologia, uma leitura particular. $\mathrm{O}$ Adão tournieriano evidentemente empresta de Platão seu hermafroditismo e a subsequente cisão, e a partir disso, a Gênese como um todo ganha um significado muito diferente. A separação do corpo andrógino em homem e mulher é ela mesma a consumação do fruto proibido, e não marca uma "queda" na história da humanidade - a palavra sequer é empregada por Tournier - mas ao contrário, uma ascensão. A cisão fundamental oferece ao homem o conhecimento da falha, do mal e do bem, da incompletude. Tal incompletude, é importante ressaltar, não pode ser revertida nem aplacada pela união matrimonial, que seria o correspondente direto da busca dos amantes platônicos. A união entre homem e mulher pelo casamento, no texto de $L e$ Roi des Aulnes, cumpre uma transgressão, uma violação da vontade divina: não se re-une o que Deus separou (BOULOUMIÊ, 1988).

Assim, Tournier elabora uma versão mais agnóstica e menos idealista da união heterossexual (o que é bastante irônico para um texto com uma intertextualidade tão notável com a tradição cristã) e desloca para a união simbólica adulto - criança a chave para a recuperação da unidade perdida. O deslocamento tem sua razão de ser: a união entre homem e mulher já não é capaz de recuperar a plenitude - e nisso temos em Abel Tiffauges um amante desastrado, incapaz de lidar e amar Rachel porque tal união aproxima partes que se completam e ao mesmo tempo se repelem. O masculino e o feminino ${ }^{11}$ se tornam, por sua constituição fisiológica inicial,

\footnotetext{
${ }^{11}$ É preciso sublinhar, sem que isso se torne um grande desvio no texto, que há nessa figuração do feminino de Tournier uma carga misógina latente. O feminino limita-se à sua fertilidade, é um anexo
} 
dualidades incompatíveis: o nômade e o sedentário. Eis o motivo, possivelmente, para que o feminino seja excluído da equação restauradora do ser original, ele existe de modo subjacente, indireto, ele está contido no ato fórico na medida em que o corpo feminino gesta um bebê. Um homem que carrega uma criança está em pleno desenvolvimento da função feminina por excelência e cumpre, em si, a unidade fundamental.

Sob a perspectiva do ato fórico, o Adão primordial, hermafrodita e solitário, cristaliza um mito de origem em direção ao qual o protagonista se volta. No capítulo anterior, determinamos que a foria é a mímese através da qual Abel procura apreender simbolicamente a essência radical do humano e vivenciar fisicamente o êxtase da plenitude perdida. Sendo assim, o mito adâmico não se posiciona apenas como um ponto de partida remoto, ele é reiterado, restituído, ele se faz presente todo o tempo, mesmo que a cada vez Abel incorpore elementos de outras narrativas, como a de São Cristóvão e o Rei dos Álamos.

\footnotetext{
sexual a ser deixado de lado quando convém, é um corpo de segunda linha: "on comprend pourquoi la femme n'a pas à proprement parler de parties sexuelles, c'est qu'elle est elle-même une partie sexuelle: partie sexuelle de l'homme trop encombrante pour un port permanent, et donc déposée la plupart du temps, puis au besoin de reprise" (TOURNIER, 1970, p. 31).

Certamente, não se trata de um romance a respeito do feminino, é antes de mais nada um romance protagonizado por personagens masculinas, num mundo masculinizado. Problemático não é apenas que se naturalize e fixe o corpo da mulher de maneira conservadora na função da gestante, mas também que se funde, a partir de Eva, uma espécie de legado do sedentarismo e a ele se atribua características aniquiladoras. O risco de perceber no mito uma etiologia reside justamente nisso, na possibilidade que se abre para um entendimento discriminatório a respeito das pessoas, das comunidades, das vidas.

Mais adiante, no romance, Tiffauges nota que os povos perseguidos são povos nômades, descentes míticos de Adão e Abel. Os nazistas, como a maioria dos povos, são sedentários, descendentes de Eva e Caim. As pessoas oriundas da raiz feminina, ou da natureza feminina, portanto, tendem a ser castradoras, cerceadoras, assassinas, ogras.

Não é o foco desta pesquisa analisar as questões de gênero em Le Roi des Aulnes, tampouco este é o aspecto mais relevante da obra. Entretanto, é importante não se furtar a observações assim, que identifiquem num texto literário traços de preconceito e que façam as devidas ressalvas e críticas, de acordo com o avanço da cultura e das mentalidades.
} 
Finalmente, o mito adâmico configurado no romance, diferente dos dois textos a partir dos quais foi desenvolvido, não tem uma intenção etiológica marcada. Quanto ao texto bíblico, é evidente que a consumação do fruto proibido se apresenta como a causa primeira da falha e do sofrimento humano, posto que Adão e Eva foram destituídos do Éden. No caso do texto de O Banquete, como dissemos, procura-se explanar a essência mesma do amor e dos males que em nome dele sofremos. Tournier funde dois mitos voltados inteiramente à condição humana, extraindo deles a potência discursiva e imagética sem, contudo, reproduzir sua pretensão explicativa - sustentamos que a função simbólica do romance é predominante. Embora a cisão, no texto de Tournier, tenha proporcionado as condições para que a existência não fosse plena, ela também marca a ascensão do homem ao nível do conhecimento e da consciência. O romance, então, sugere apenas parcialmente que a dissolução do corpo andrógino é uma causa de todo o mal humano, e nisso ele mantém o equilíbrio entre as formulações míticas e históricas. Mais do que isso, ele mantém sua mitologia no campo do simbólico, como Ricœur sugere que os mitos sejam lidos; a mitologia de Le Roi des Aulnes se presta antes a desvelar o sentido das experiências do que a justificá-las.

\subsubsection{Indícios do caos na narrativa}

Aproximar o mito adâmico de Ricœur do Adão do romance é um tentativa de investigação mais detalhada a respeito dessa lacuna existencial de que Abel Tiffauges é caudatário. Não significa, contudo, que a hipótese da qual partimos conta com uma consonância harmônica entre a teoria e a configuração literária. 
Antes, é esperado que a ficção de Michel Tournier conduza a contradições e dissonâncias em relação à estrutura mítica descrita na abordagem filosóficoteológica de Paul Ricœur. Sendo assim, poderíamos afirmar que o sistema mítico de Le Roi des Aulnes trabalha num hibridismo tipológico, que ele empresta das modalidades de "mitologia da criação" elementos que não necessariamente se tocam nas comunidades e culturas reais, mas que dentro da obra se prestam bem à configuração mítica.

Nossa cautela não poderia ser menor, considerando que já na primeira página, no primeiro parágrafo mesmo, o narrador faz menção a um estado de pré-criação que coloca em questão o achèvement do mito da criação pela Palavra no qual o mito adâmico está completamente inserido:

Or moi, j'étais là déjà, il y a mille ans, il y a cent mille ans. Quand la terre n'était qu'un ciel d'hélium, l'âme qui la faisait flamber, qui la faisait tourner c'était la mienne. Et d'ailleurs l'antiquité vertigineuse de mes origines suffit à expliquer mon pouvoir surnaturel : l'être et moi, nous cheminons depuis si longtemps côte à côte, nous sommes de si anciens compagnons que, sans nous affectionner particulièrement, mais en vertu d'une accoutumance réciproque aussi vieille que le monde, nous nous comprenons, nous n'avons rien à nous refuser. (TOURNIER, 1970, p. 13-14, grifos nossos) ${ }^{12}$

\footnotetext{
${ }^{12}$ Cabe uma observação em relação a este trecho. A leitura dos Écrits Sinistres feita neste trabalho não pressupõe neles uma literalidade integral, isto é, há notadamente passagens em que o narrador Abel Tiffauges se entrega ao devaneio e parece confundir os limites entre o que é onírico, imaginário, ilusório e o que é factual, evento, concreto.

Como dissemos anteriormente, enquanto narrador, Tiffauges promove uma interpretação muito particular da Bíblia, e por extensão do mito adâmico. Se, no romance, a figura de um andrógino primordial torna-se de fato o referencial a partir do qual a dimensão mítica se constitui, isso se deve tão-somente ao trabalho narrativo engendrado na primeira parte da obra. É intenção desta pesquisa manter a fala de Tiffauges sob desconfiança e análise constantes, sem subtrair-lhe, entretanto, a capacidade determinante dentro de uma estrutura literária específica. Desta maneira, as certezas e convicções de Tiffauges não são nunca interpretadas sob o crivo do certo e do errado, do verdadeiro ou do falso, mas dentro do que é ou não coerente e próprio das narrativas: a sua e a do narrador externo. Se o discurso de Tiffauges tem potência o bastante para definir um mito de origem coerente, se a trajetória da personagem se ampara e sustenta esse mito, a afirmação e o testemunho sobre
} 
Certamente nada nesse trecho, e em nenhum outro em todo o romance, indica um caos anterior à criação do mundo de acordo com os parâmetros e características que Ricœur apresenta. Não há, como dissemos, nessa dimensão mitológica de Le Roi des Aulnes, outros agentes ou entidades que respondam em nome do divino, do sobrehumano, não há indícios de luta ou conflito entre deuses, nenhum esboço de uma teogonia. Ainda assim, que o personagem remeta a um tempo anterior mesmo à matéria terrena, antes que houvesse um planeta e a vida que ele propicia, e que o protagonista se coloque ao lado de um "ser" indefinido e absoluto, isso problematiza em certa medida a correspondência entre o mito da criação configurado na obra com o drama da criação de Ricœur.

Tiffauges projeta para si uma antiguidade tal que não the cabe sequer reclamar a ancestralidade dos homens, pelo contrário, ele não se confunde com ela. A potência de seu espírito é de outra ordem, está ligada a uma espécie de força vital do planeta, da criação: a alma que fazia a terra girar e arder. A paridade que o coloca lado a lado com a existência, em seu núcleo mítico e mínimo, paradoxalmente tem a ver com o desenvolvimento histórico desta mesma existência, pois a alma de Abel e o ser são companheiros habituados um ao outro, ligados por uma afinidade mútua sem afetação.

Insere-se na trama um elemento estrangeiro ao mito da criação pela palavra, que afasta inclusive a entidade bem delineada do Deus criador. A linguagem empregada para criar essa referência aos tempos de pré-criação compõe, afinal, uma imagem onde geologia e mito se confundem, na qual um céu de hélio gira há cem mil anos

um tempo ainda mais remoto não podem ser prontamente classificados como devaneio e descartados. 
impulsionado por uma alma sobrehumana. É coerente com nossa metodologia de interpretação que essa passagem tipicamente tiffaugeana acerca da própria grandiosidade seja recebida como um símbolo, como todas as passagens semelhantes o são. Ora, considerando o caráter da personagem, e sua inclinação às interpretações megalomaníacas dos eventos, somos levados a crer que essa antiquidade é uma projeção de sua personalidade mítica, é uma construção a posteriori que ele empreende para "explicar seu poder sobrenatural" e sustentar sua natureza feérica, mítica, ogra - como demonstramos no primeiro capítulo.

Mas, também, é um símbolo que simplesmente impede que a criação do mundo seja entendida, no sistema cognitivo específico do romance, como um evento dado. A criação não é dada, completa e encerrada, tampouco é necessariamente positiva, ou tranquila. Há na criação uma espécie de brutalidade mineral ardente, incendiada por um espírito capaz de mover a terra e a ela permanecer indiferente. Tiffauges extrapola sua própria alma até que ela abarque a existência toda, e nesse movimento, a partir dele, precisamente, é necessário que o leitor saiba que mesmo o mito e a história estão subordinados a uma personalidade consciente de como narrar a si mesma.

Afirmar que, no romance, a criação do mundo não é uma obra encerrada implica em aproximá-la do Drama do Caos, segundo o qual a instauração do mundo e da existência humana marcam um ponto de equilíbrio e uma possibilidade de restauração da plenitude inicial através do rito. Ora, já rejeitamos qualquer conflito teogônico na obra, assinalando, assim, que se há o caos ele não é oriundo da divindade. 
A alternativa que nos resta como chave de leitura, portanto, sugere que o caos não seja necessariamente pré-existencial, que não seja sequer divino. Mas que ele pode ser, e de fato é, instaurado no mundo humano pelas mãos humanas. Eis uma segunda corruptela do sistema mítico descrito por Ricœur: o caos, que é um elemento exclusivo do jogo e conflito de poderes dos deuses, configura-se no romance como um desdobramento das ações do homem.

Isso porque este não é um romance sobre o Éden, tampouco sobre Adão. Devemos levar sempre em conta que ele nos conta a história de como Abel Tiffauges cumpriu seu destino, internalizando, para isso, elementos externos de várias fontes. Do ponto de vista da narrativa, a trajetória de Abel marca o início e o fim da existência, ele principia e encerra a obra. Ora, trazendo para a narrativa a dimensão mitológica da personagem, temos que ele escreve, narra a si mesmo como o espírito que faz girar a terra, assim como será ele a representar a última cena do livro, devastadora e apocalíptica. Se Abel é de fato uma personagem consciente dos meios de narrar a si mesma, como acreditamos que seja, ele manuseia a palavra de acordo com sua vontade e se torna, assim, uma entidade dentro de seu próprio romance. Ele é, desde a primeira linha, o elo entre todas as camadas cognitivas da obra, ele ligará a pré-existência à aniquilação e redenção final, ele passeará entre o êxtase do Adão primordial e entre o horror dos campos de concentração; ele cumprirá a vontade de um destino que é, ao mesmo tempo, uma força transcendente e um desdobramento de si. A desconfiança em relação a Abel Tiffauges não deve por em suspenso a facticidade daquilo que ele conta, sobretudo se o parâmetro de avaliação é o nosso princípio de realidade. A desconfiança deve ser esse sussurro constante que nos diz que, afinal, Abel é o narrador que nos conduz, ele também pode criar e destruir o mundo através da palavra. 
É nesse sentido que procuramos atribuir à Shoah muito mais do que um desempenho meramente formal na narrativa, ela não é o assunto nem o contexto da trama, ela mesma é um símbolo, um agente do sistema mítico e cognitivo, ela revela o caos na existência e o alcance do mal humano. Ainda: ela revela a experiência de Abel Tiffauges no mundo, ela propicia à personagem as condições de possibilidade de atuação, de investigação a respeito de si. Se o ato fórico atinge afinal seu objetivo redentor, é porque ele encerra simbolicamente o caos aniquilador que 0 nazismo trouxe em seu bojo.

E o êxtase que a foria provoca em Abel revelam, também, uma dimensão da existência que poderia passar despercebida, a saber, a de uma infelicidade insolúvel no seio da existência. Sobre esta infelicidade essencial, sobre esta lacuna que apenas com o ato fórico se vê locupletada, já nos perguntamos. A maneira pela qual a foria restabelece a essência humana primordial e, por conseguinte, uma plenitude perdida, nos leva a entender a Shoah como uma configuração antropológica do caos, ou como a incrustação do caos naquela que é a dimensão humana por excelência: a dimensão histórica.

\subsubsection{A necessidade e a estetização da barbárie}

Mencionamos, há pouco, que Deus é uma entidade cuja função na obra limita-se ao ato da criação e da comunicação de sua finalidade: "crescei e multiplicai". Essa limitação não é secundária, importa que a condução da história humana não seja atribuída a nenhuma divindade, sob o risco de tornar contingente todos os eventos e decisões do homem. Se há uma condução sobre-humana no curso dos 
acontecimentos, no romance, ela submete-se ao que Abel chama de destino sem fazer maiores considerações. O destino apresenta-se, assim, como um elemento cuja volição é bastante clara, que parece torcer e facilitar para que as ações aconteçam deste e não daquele modo. De todo jeito, não lhe cabe o status de divindade, não Ihe cabe uma dissociação completa da personagem de Abel; o destino permanece como uma força transcendente que atua sobre a história, que torna cada evento necessário para que Abel cumpra com o destino que lhe foi designado.

A facilidade com que podemos desenvolver esse pensamento em relação aos aspectos míticos do romance não se reproduz, contudo, quando nos voltamos para sua abordagem histórica. Dizer que todos os episódios pelos quais Tiffauges passa são necessários à economia da obra torna os campos de concentração, a guerra e a ideologia nazista necessários à sua história particular. E, por extensão, necessários à História da humanidade: "Tout cela lui était donné par le destin, comme lui avaient été donnés l'incendie de Saint Christophe, la drôle de guerre et la débâcle" (TOURNIER, 1970, p. 243)

Não é sem uma certa perplexidade que nos deparamos com uma afirmação destas. Como a necessidade histórica do horror não iria contrariar qualquer oposição que se faça a ele?

Já mencionamos no começo da pesquisa que o sistema mítico desenvolvido por Tournier já se opõe estruturalmente às formas e arquétipos nazistas. Além disso, em várias passagens do texto encontramos críticas ao programa nazista, em especial no capítulo L'Astrophore, com suas evocação a Auschwitz e as câmaras de gás, os experimentos médicos e o padecimento dos prisioneiros. 
À trente kilomètres au sud-est de Katowice, en Pologne, que les Allemands appelaient Auschwitz. C'était L'Anus Mundi, la grande métropole de l'abjection, de la souffrance et de la mort vers laquelle convergeait de tous les points de l'Europe des convois de victimes. Éphraïm y était arrivé si jeune qu'il lui semblait y être né, et il paraissait presque fier d'avoir grandi dans cet abîme qui se parait d'un prestige funèbre aux yeux du peuple concentrationnaire. (...) Puis Éphraïm raconta le supplice des appels qui pouvaient durer jusqu'à six heures, et pendant lesquels les détenus devaient demeurer debout, immobiles quelle que fût la température. (...)

J'ai assisté à des sélections. Une fois, j'ai donné du rouge pour une femme pour qu'elle s'en mette sur les joues et paraisse moins malade. Un jour en hiver, un kapo nous a permis d'entrer dans les chambres à gaz pour nous réchauffer. C'était des fausses salles de douches. On faisait déshabiller les condamnés en leur recommandant de bien noter où étaient leur vêtements pour pouvoir les retrouver. On distribuait même des serviettes. Ensuite, on entassait le plus possible d'hommes et de femmes dans la pièce. (...) Quand on ouvrait les portes après les gazages, on voyait que les plus forts avaient piétiné les autres pour échapper aux vapeurs mortelles. (...)

Éphraïm connaissait l'existence du quartier B, où Dr Mengele se livrait à ses expériences médicales sur les détenus (...) d'expériences de mort sous vie pour apprendre à remédier aux suites psychologiques de la dépressurisation accidentelle des avions (...). (TOURNIER, 1970, p. 474-478)

O relato de Éphraïm é extenso e bastante específico. Ele é tão mais aterrador por ser transmitido por uma criança que, calmamente, descreve as maneiras de se viver e morrer no campo de Auschwitz. A força da imagem é inegável, ela faz eco com algumas passagens de Walter Benjamin em seu magnífico ensaio $O$ Narrador (BENJAMIN, 1994), invertendo alguns de seus termos. O filósofo nos fala sobre a experiência transmitida dos mais velhos para os mais novos a fim de comunicar-lhes o sentido último da existência. E, se os soldados voltaram mudos da trincheira porque não tinham nada a narrar, o menino vem de um campo de concentração com um testemunho rico em detalhes capazes de chocar mesmo alguém iniciado como Tiffauges. 
Resta, portanto, analisar se, à revelia desses elementos que indicam resistência e combate a tudo o que o nazismo representou e criou, a trama seja caudatária de um determinismo cruel que justifica, em alguma medida, a Shoah.

Houve um jornalista que se irritou particularmente com a abordagem de Tournier e o acusou, numa ocasião, de constituir "uma estetização da barbárie" (BOULOUMIÊ, 1988, p. 105). Ao que o escritor respondeu:

Certes, la barbarie que je décris dans Le Roi des Aulnes est esthétique, tout le côté wagnérien, tout le côté fête, cathédrale de lumière, le côté grande parade... Mais ce n'est pas ma faute. C'est parce que cette barbarie, en effet, était esthétique. Ce n'est pas moi qui l'ai inventée. Je lui ai rappelé un mot de Léon Blum : "Le communisme est une technique, le socialisme une morale, le fascisme une esthétique ». Que ce soit celui de Hitler ou celui de Mussolini, le fascisme est inséparable d'un certain faste wagnérien avec des défilés, de la musique, des monuments qui se ressemblent tous et des fêtes nocturnes avec des flambeaux, des projecteurs qui se rejoignent en voûte. Et si vous faites abstraction de cet aspect du nazisme, vous le dénaturez, vous en donnez une image imparfaite... C'était une fête nocturne, une fête meurtrière... Ce n'était pas ridicule, c'était terrifiant... Si on donne une image totale du nazisme, ce que j'ai fait dans le Roi des Aulnes, il faut décrire sa vitrine, avec ses fêtes, avec ses fastes, toute cette séduction par la violence et en même temps, naturellement, l'arrière-boutique avec ses camps de concentration et son côté meurtrier éminent. Les deux choses sont inséparables. (BOULOUMIÊ, 1988, p. 115)

A resposta que procuramos formular, seguindo um pouco a lógica da fala do autor, é que a necessidade histórica da Shoah, na economia da obra, ou seja, dentro da lógica interna da narrativa, é ela mesma uma questão estética. É porque a propaganda nazista tinha proporções e feitos de espetáculo, como afirma Tournier, conjugadas a um programa de genocídio violento e extremo, que ela se torna necessária na figuração do horror e do mal no texto. $O$ mito que este romance procura representar une duas pontas de uma história que se desenvolve no infinito, mas precisa de um evento histórico de feições monstruosas e trajetória ascendente. É preciso que uma guerra se preste à apoteose, que tenha um caráter plástico, 
ritualístico; é preciso que o caos seja instaurado por um sistema que, passando pela racionalização mais sóbria, toque o injustificável.

Trata-se meramente uma especulação, por certo, mas a simbiose com que a personagem de Abel se insere no corpo da máquina nazista, a maneira como essa experiência potencializa sua própria trajetória, a similaridade com que os símbolos se constroem em conjunto, tudo isso nos leva a crer que o romance, a história que ele conta, existe porque as referências à Shoah são reais, calcadas na memória e na pesquisa do autor.

De maneira análoga, Tiffauges nos faz crer que também ele desempenhou um papel necessário ao programa nazista quando trabalhou no recrutamento dos jovens das aldeias próximas a Kaltenborn. Já dissemos que para Tournier o nazismo era um programa voltado aos jovens, que seu objetivo maior era criar, afinal, uma geração ariana prostrada diante de sua ideologia. Não se lhe escapa essa vocação devoradora, antropofágica mesmo, dos nazistas:

Les nazis avaient su au début tirer adroitement parti des mouvements des Wandervögel (oiseaux migrateurs) qui avaient fleuri en Allemagne au lendemain de la Première Guerre mondiale et les canaliser dans leur propre organisation, la Hitlerjugend. Le racisme se greffant sur cette «juvénophilie » l'aggrave de raffinements maniaques. Car on va s'intéresser désormais aux enfants dès leur plus jeune âge - ce n'est plus seulement des petits soldats que l'on veut, c'est la substance biologique de la nation charnelle qui est en cause - et la juvénophilie tourne à la pédophilie. (TOURNIER, 1977, p. 106)

Tournier não pode separar a festa noturna e assassina do nazismo nos campos de concentração, do mesmo modo, ele não pode dissociar completamente o caráter contingente da guerra do estabelecimento necessário do mal, que por sua vez conduzirá à cena da redenção final. A questão da adesão de Tiffauges ao nazismo 
se apresenta nesse movimento, justamente, como corolário da necessidade da barbárie para a economia textual.

Decantar as atitudes de Abel nos leva à suspeita legítima de que, afinal, ele compactua com o nazismo e portanto é conivente com a barbárie e o caos. Essas questões surgem porque lidamos com um texto ambíguo, polêmico, cuja trama e personagens atuam numa zona limítrofe. Em relação a Tiffauges, sua participação junto ao algoz, ou seja, junto aos nazistas, conta com as mesmas justificativas que colocaram a barbárie na conta da narrativa: era imprescindível que ele se misturasse a um sistema do qual discordaria para, além de entende-lo, descobrir a si mesmo.

Car il n'avait pas seulement la vocation de déchiffrer les essences, mais aussi de les exalter, de porter toutes leurs vertus à incandescence. II allait livrer cette terre à une interprétation tiffaugéenne, et en même temps, il l'élèverait à une puissance supérieure, encore jamais atteinte (TOURNIER, 1970, p. 243)

A trajetória de Abel é praticamente toda orientada por sua vocação "ogresca", para usar uma terminologia própria ao livro, que encontra respaldo nas instituições nazis. Vemos que suas perversões, inclinações e atos, seus desejos e motivos, tudo entra em consonância com uma espécie de morfologia do nazismo, ainda que em relação a ele, Tiffauges tenha ímpetos reparadores.

Certes le S.S. lui inspirait la plus vive répulsion. Mais déjà la napola - dont la discipline, les uniformes et les chants forcenés heurtaient ses goûts et ses convictions d'anarchiste - obligeait à toutes les concessions parce qu'elle se révélait bien évidemment comme une machine à soumettre et à exalter tout ensemble la chair fraîche et innocente. Cette soumission, cette exaltation, l'érudition maniaque de Blättchen - toujours à la limite du sadisme et du crime - les portait à leur comble (...). La cohérence de son évolution, et, surtout, le bond en avant qu'il avait accompli en passant des cerfs et des chevaux aux enfants lui prouvaient assez qu'il marchait dans la voie de sa vocation. Restait à être plus fort que la circonstance et à trouver le moyen de s'approprier le domaine de Blättchen pour le gauchir à sa manière, de même qu'il avait su tirer de Rominten des fruits imprévus et purement tiffaugéens" (TOURNIER, 1970, p. 337) 
Esses ímpetos reparadores, essa vontade de se apropriar e "gauchir" o reino de Blättchen jogam um foco de luz sobre as balizas que enfim situam o Bem e o Mal na obra. Na verdade, a discussão sobre a configuração do mal compreende mais de um aspecto. Analisaremos, a seguir, o conceito de inversão para, enfim, nos ocuparmos da vocação ogra de Abel Tiffauges.

\subsubsection{Inversão maligna, inversão benigna}

O debate a respeito do mal no romance não pode de maneira alguma contornar o conceito de inversão; este é o eixo, o cerne mesmo que fundamenta qualquer formulação a respeito de bem e mal na obra. São inúmeras as passagens em que Abel menciona uma inversão, variando entre inversão maligna e inversão benigna.

$\mathrm{Na}$ primeira e breve abordagem que fizemos do conceito, estabelecemos que a inversão é um mecanismo que atua sobre as coisas revertendo seu significado positiva ou negativamente no romance. Arlette Bouloumié (1988, p. 20) descreve a inversão como o conceito organizador da obra, aquilo que the confere unidade e coerência entre os elementos. O conceito, aliás, não é exclusivo de Le Rois des Aulnes, ele na verdade está presente em diversos romances, contos, artigos e mesmo comunicações do escritor; ele permeia sua visão de mundo e interpretação geral dos fenômenos.

Tournier tem certo fascínio pelo duplo freudiano, por simetrias e analogias, e assim a inversão funciona como uma espécie de espelho que reflete uma imagem idêntica à original, introduzindo todavia uma diferença sutil, essencial. Uma oposição que conta 
com a semelhança, que esvazia um elemento ou uma ação quaisquer de sua carga "moral" e o reformula, produzindo o efeito contrário. É assim que Tournier alcança, em seus textos, o mal através de algo inicialmente bom e, naturalmente o contrário, o bem através de algo inicialmente maligno.

A inversão benigna está, por exemplo, na primeira experiência de foria por que passa Tiffauges. Ele descreve como o peso de uma criança, acrescido ao seu próprio peso, não resultou numa sensação de fardo mas, antes, de leveza. O bem estar, o êxtase fórico é uma inversão benigna que se manifesta sensivelmente, de maneira profunda com o corpo e a consciência:

Jeannot n'est pas gros certes, mais il doit bien peser dans les quarante kilos, lesquels s'ajoutèrent aux quelques cent dix kilos que je pèse moi-même. Or c'est par un sentiment de légèreté, d'allégement, de joie ailée que mon « extase phorique » se définit le mieux. Une manière de lévitation provoquée par une pesanteur aggravée ! le mot inversion se présente aussitôt sous ma plume. II y a eu quelque sorte de changement de signe : le plus est devenu moins, et réciproquement. Inversion bénigne, bénéfique, divine... (TOURNIER, 1970, p.114)

Dentro da narrativa, a essência da inversão tem relação com a experiência transcendental da personagem, da qual já falamos anteriormente. Se consideramos que o ritual é capaz de viabilizar um contato com uma existência sagrada, mítica, atemporal e sobrehumana, então aceitamos definitivamente o intercâmbio entre as esferas metafísicas. Eis, justamente, o cenário que a obra nos apresenta em sua dimensão mítica: há o bem, há o mal, e há a ação, a escolha individual que rege cada uma das vidas. Como agentes, há Deus, assim como há o Diabo e os homens, mesmo que alguns deles possuam uma natureza monstruosa, feérica, como é o caso de Abel, e atinjam mais facilmente as dimensões transcendentes. 
A inversão benigna constituiria, portanto, uma ascensão da existência, um canal momentaneamente aberto entre o homem e a divindade. Ora, se estamos lidando com uma estrutura simétrica, naturalmente a inversão maligna seria o acesso do mal mais demoníaco e obscuro no plano humano. Eis, exatamente, a figuração que Tiffauges faz a respeito do mal. Ele identifica e nomeia o Diabo não apenas como o avesso de Deus, mas como uma entidade que influencia os homens e promove a inversão maligna.

\begin{abstract}
Satan, maître du monde, aidé par ses cohortes de gouvernants, magistrats, prélats, généraux et policiers, présente un miroir à la face de Dieu. Et par son opération, la droite devient la gauche, la gauche devient la droite, le bien est appelé mal, le mal appelé bien. (...) (TOURNIER, 1970, p. 106)

La guerre, mal absolu, est fatalement l'objet d'un culte satanique. C'est la messe noire célébrée au grand jour par Mammon et les idoles barbouillées de sang devant lesquelles on fait agenouiller les foules mystifiées s'appellent: Patrie, Sacrifice, Héroïsme, Honneur. (TOURNIER, 1970, p. 107)
\end{abstract}

A vocação profética e teológica dessa formulação é evidente, e como dissemos, ela se encaixa dentro de uma esfera do romance que lida explicitamente com a mitologia judaico-cristã mas que ao mesmo tempo a radicaliza, expondo todo e qualquer mal sob o signo da influência satânica. É por esta razão que a inversão se torna, como afirma Bouloumié (1988, p. 33), "a chave que permite a Michel Tournier elaborar uma interpretação religiosa do nazismo". Concordamos apenas em termos que seja esta a base da interpretação de Tournier. Indiscutivelmente ele conferiu uma roupagem mítico-religiosa a todo o evento da guerra e das motivações e práticas nazistas. Mas ao associar o nazismo a cultos demoníacos, missas e prostrações, e mobilizar um vocabulário religioso para se referir a um fato político, Tournier certamente não está negligenciando o caráter institucional do mito, de que 
falamos no início deste trabalho. Assim, concordamos com Bouloumié desde que feita a seguinte ressalva: a inversão proporciona uma interpretação religiosa do nazismo com intenções políticas, pois a mitificação do nazismo ocorre em dois eixos, o metafísico e o político. O eixo metafísico do romance, como sabemos, conjuga os fatos históricos a uma malignidade humana por vezes atribuída a uma entidade demoníaca - eis o porquê de Bouloumié referir-se a uma interpretação religiosa. No campo discursivo político, temos o caráter oficial, doutrinador e repressivo do nazismo, projetado na seleção de crianças para a juventude hitlerista. Isto é, a motivação essencialmente má do nazismo - e portanto religiosa - revertese também numa atitude política condenável, abjeta, repugnante. A capacidade de forja de uma "abóbada comum", que constitui via de regra o caráter institucionalizador do mito, no romance ganha uma roupagem estratégica, bélica, mundana. Por esta razão, defendemos que todo o caráter religioso do romance existe dialeticamente em função do caráter político, de modo que não se pode lidar com apenas um deles na leitura.

Por ora, interessa analisar a roupagem mítico-religiosa que o escritor conferiu ao nazismo, que seria então motivado por sucessivas inversões malignas, por apropriações e distorções de aspectos da existência humana que são então desconsiderados. Uma dessas apropriações aparece na oposição entre pureza e inocência, que o narrador desenvolve da seguinte maneira:

L'innocence est amour de l'être, acceptation souriante des nourritures célestes et terrestres, ignorance de l'alternative infernale pureté-impureté. De cette sainteté spontanée et comme native, Satan a fait une singerie qui lui ressemble et qui est tout l'inverse : la pureté. La pureté est l'horreur de la vie, haine de l'homme, passion morbide du néant. Un corps chimiquement pur a subi un traitement barbare pour parvenir à cet état absolument contre la nature. L'homme chevauché par le démon 
de la pureté sème la ruine et la mort autour de lui. Purification religieuse, épuration politique, sauvegarde de la pureté de la race, nombreuses sont les variations sur cette thème atroce. (TOURNIER, 1970, p.125)

Os dois últimos excertos nos fornecem indícios o bastante para notar que a interpretação do nazismo, na obra, possui um caráter religioso muito forte. Com efeito, a ideologia nazi teria dado corpo, método e alcance a um projeto que em sua essência é uma apropriação do demoníaco. Em outros termos, o nazismo representou na terra a institucionalização do mal mais profundo, ele erigiu no centro da Europa um espaço de culto e prostração de Satan com sua militarização, alistamento de crianças, campanhas idealistas, festas de rua. Todo o caráter ritualístico do nazismo, que já abordamos na parte "Estetização da barbárie", assume aqui, de maneira mais intensa, sua vocação mítico-religiosa.

Culturalmente, a depuração da raça corresponde à inversão maligna da inocência, que seria um estado de consciência livre da cisão entre bem e mal, certo e errado. A pureza, como afirma o narrador, é uma corruptela, uma inversão da inocência aplicada à corporeidade e à mentalidade das pessoas, é um desejo de aniquilação do humano, da falha, da mácula. A esta obsessão pela pureza física e mental opõe, aliás, Abel Tiffauges em si, tão afeito à escatologia e às perversões. Diante do ascetismo nazista, a monstruosidade de Abel o torna mais humano, mais próximo da corporeidade rejeitada pelo sistema.

Entre Abel e o nazismo, aliás, figuram de tal modo a similaridade e a inversão que a personagem, quando ouve o relato de Éphraïm a respeito dos campos de concentração, reconhece um a um seus projetos de uma "Cidade fórica" idílica e benigna; como se ele mesmo tivesse acesso a toda essência criadora do espírito humano, e duelasse simbolicamente com uma força igual, porém contrária, que 
também pretendesse reconstruir aquela terra com os mesmos elementos mas com finalidades opostas:

\begin{abstract}
Dès lors, le rôle des dobermans concentrationnaires, dressés à pourchasser et à déchiqueter à mort les détenus, ne lui sembla plus qu'une touche presque légère, destinée à parfaire la monstrueuse analogie, cette contresemblance qui était son enfer personnel. En revanche la révélation des chambres à gaz maquillées en salles de douche acheva de le désespérer. (TOURNIER, 1970, p. 477)

Abreuvé d'horreur, Tiffauges voyait ainsi s'édifier impitoyablement, à travers les longues confessions d'Éphraïm, une Cité infernale qui répondait pierre par pierre à la Cité phorique dont il avait rêvé à Kaltenborn. Le Canada, le tissage des cheveux, les appels, les chiens dobermans, les recherches sur la gémellité et les densités atmosphériques, et surtout, surtout, les fausses salles de douche, toutes ses découvertes se reflétaient dans l'horrible miroir, inversées et portées à une incandescence d'enfer. (TOURNIER, 1970, p. 479)
\end{abstract}

Se, por um lado, uma explicação mítico-religiosa, ou metafísica nos termos de Bouloumié (1988, p. 35) para os fundamentos do nazismo nos parece aceitável e coerente com a dimensão mítica do romance, por outro é preciso reconhecer o problema ético e moral que tal etiologia pode representar.

É próprio das mentalidades indiferentes, e mesmo reacionárias, fixar a fonte do mal humano (e por conseguinte inserir todo o horror da Shoah) num mecanismo de inversão moral e atribuir esse mecanismo exclusivamente ao diabo. Uma tentativa de explicação do horror nesses termos pode abrir espaços para uma espécie de desresponsabilização do homem de modo geral - e pontualmente dos homens que cometeram as atrocidades em nome do regime nazista - por sua própria condição. Ou seja, o que está em jogo é o caráter antropológico do mito do mal humano, já analisado neste trabalho, uma vez que Satan "pessoalmente" se apresenta como origem e agente do mal e dos mecanismos de aniquilamento. Eis o problema que se coloca: como entender a inversão maligna, fonte do substrato espiritual que motivou o nazismo, sem descaracterizá-lo mas igualmente sem conferir-lhe tal significado? 
Isso posto, ressaltamos que a inversão atua como um conceito organizador porque capta e processa todos os símbolos, ela é o crivo que legitima o caráter metafísico do cotidiano. Ainda, é através dela que o narrador - seja Tiffauges ou o narrador externo - liga cada um dos elementos de seu discurso de maneira lógica e heterogênea, ela é o próprio mecanismo sintético da narrativa. Em outras palavras, a inversão maligna e a inversão benigna são as duas vias de uma mesmo processo dinâmico de ressignificação interna ao texto. Para além de seu alcance metafísico está sua capacidade metalinguística, ou seja, enquanto estratégia discursiva, a inversão recria, dentro do texto, versões dele mesmo de maneira a fazer evoluir a narrativa.

Ora, em muitos contextos, nós diríamos que a inversão proporciona, dentro das balizas cognitivas da obra, inúmeras releituras de suas próprias estruturas, constituindo assim um sistema refinado e complexo de auto-referenciação e intertextualidade. Arlette Bouloumié afirma que o texto de Michel Tournier orienta-se sempre no sentido de provocar um "dépassement des apparences" (1988, p.20). Essa intenção reveladora de um significado latente e subjacente é, afinal, semelhante à função que Ricœur dá aos símbolos nos sistemas mitológicos: eles devem sugerir uma compreensão da existência que simplesmente nos escaparia caso o símbolo não a revelasse.

Eis que surge, no seio de uma observação discursiva, uma chave para a dissolução do problema que então se apresenta. Poderíamos afirmar que a inversão tiffaugeana, seja maligna ou benigna, cumpre exatamente as mesmas funções do símbolo de Ricœur: ela revela na História uma dimensão metafísica que não é perceptível. Evidentemente, isso faz sentido na estrutura textual e narrativa de Le 
Roi des Aulnes. De todo jeito, a questão se abre no campo da hermenêutica e permite, sim, que a inversão seja compreendida como uma etiologia para o mal. É, aliás, a interpretação que Arlette Bouloumié procura sustentar:

La dimension mythique du roman implique d'ailleurs l'intervention de puissances surnaturelles, ici diaboliques, provoquées par l'usage perverti des symboles. (...) L'inversion maligne donne donc une interprétation mystique, transcendante aux événements historiques. (BOULOUMIÊ, 1988, p. 35)

Nesse ponto, discordamos da pesquisadora pelos motivos que expusemos logo acima. Creditar ao mito toda a responsabilidade, toda fonte do mal seria não apenas defender uma teoria insensível em relação aos milhões de vítimas do Terceiro Reich, mas também tornar vã a própria narrativa. Se esta é uma narrativa que procura demonstrar que o Demônio exerce sobre os homens uma influência tal que somos capazes, em nome dele, de cometer as piores atrocidades, então todo o sentido da resistência e da crítica ao nazismo se torna contingente e superficial. Pelo contrário, percebemos no romance diversas camadas cognitivas, e algumas delas estão incrustadas nas questões textuais, estruturais, simbólicas.

Retomando o que dizíamos, a inversão maligna cria, de fato, uma ligação direta entre o conceito do Mal e o nazismo, acrescentando a esta equação a participação de uma entidade demoníaca. Esta ligação surte seus efeitos na trama pois ajuda a estruturar toda a ação e a dinâmica da narrativa, ela pode inclusive estabelecer uma relação etiológica mais imediata. Porém, em suas camadas mais profundas, a inversão nos mostra a transitividade entre o mito e a humanidade, entre a dimensão metafísica e a dimensão histórica. A transitividade, é certo, funciona em dois sentidos: ela tanto mostra como forças sobrenaturais podem influenciar as ações 
humanas tanto quanto podem demonstrar como, no curso do tempo, o homem agiu de modo a recriar o horror em suas dimensões mais irreais e inacreditáveis.

Finalmente, e como contra-exemplo da origem demoníaca do mal, que prevalece no romance mesmo com as devidas ressalvas, segue uma passagem do romance que configura, a nosso ver, uma instância de malignidade essencialmente humana. Para este episódio não há atribuição mítica, mas ele salta aos olhos por um princípio ético nosso: um rastro de malignidade que evoca o assassínio, a crueldade, as muitas formas de aniquilação.

Essa primeira instância, aliás, sequer se concentra nos fatos que ocorrem dentro da Alemanha. Quando Abel Tiffauges testemunha o enforcamento de um condenado em praça pública, percebe abismado a sanha da multidão que quer e anseia pela execução de Weidmann.

Ainsi la peine de mort n'est pas une sanglante survivance des temps barbares, toutes les enquêtes d'opinion publique ont prouvé que la grande majorité des gens y demeure aveuglement attachée. (TOURNIER, 1970, p. 57)

L'abject Lebrun vient de repousser le recours en grâce de Weidmann. (...) Mais quoi qu'il en soit, y a-t-il un crime plus abominable que celui de cet homme chamarré, assis derrière son bureau monumental, libre de toute pression, qui refuse d'accomplir le petit geste qui arrêterait la perpétration de l'assassinat légal?" (TOURNIER, 1970, p. 159)

"C'est grotesque, c'est abominable. (...) Accroupi sous le trône de Mme Eugénie, je vomis de la bile." (TOURNIER, 1970, p. 164)

Une force obscure contre laquelle j'ai vainement lutté m'a incliné à céder aux supplications de Mme Eugénie qui voulait que je la mène avec des voisines hier soir à Versailles où devait avoir lieu l'exécution de Weidmann. L'ignoble fébrilité dont ces femmes donnaient le spectacle aurait certes suffi à me détourner (...).

Dès les abords de la ville, on sent qu'il se passe quelque chose (...), il flotte dans l'air comme une complicité crapuleuse. Tous ces hommes, tous ces femmes, ces enfants même sont venus pour la même chose, et ils le savent. (TOURNIER, 1970, p. 160) 
Mais toute la bonne humeur s'en est allée. La foule hargneuse ne comprend plus pourquoi on la fait attendre. Elle s'en veut enfin pour son argent. Soudain trois syllabes scandées d'abord de façon sporadique sont reprises sur un rythme rageur par cent mille gosiers : Co-mmen-cez, co-mmen-cez, co-mmen-cez ! Suis-je vraiment le seul à me sentir écrasé par l'infamie de ces gens ? (TOURNIER, 1970, p. 162)

Todo o episódio da pena capital, a angústia e a raiva com que Tiffauges testemunha o comportamento bestial e sanguinário das pessoas fornece alguns indícios a respeito da malignidade inerente às pessoas. Não é uma formulação nova, nem impressionante, que as pessoas tenham inclinações para a barbárie, para a crueldade, que a aniquilação do outro possa servir como espetáculo, mas nesse contexto, ela nos mostra que nem todo ato é creditado a uma força maligna diante da qual os homens sucumbem.

A oposição de Tiffauges à execução de Weidmann, inclusive, faz emergir uma crítica política, uma recusa à institucionalização da morte, ao mecanicismo das relações: "y a-t-il un crime plus abominable que celui de cet homme chamarré, assis derrière son bureau monumental, libre de toute pression, qui refuse d'accomplir le petit geste qui arrêterait la perpétuation de l'assassinat légal?' (TOURNIER, 1970, p. 159). Não é exatamente uma manifestação de resistência refinada ou profunda, mas, como dissemos, trata-se apenas de uma primeira camada na configuração do mal no romance cujo substrato são as pessoas, as mais comuns, tiradas de seu cotidiano e colocadas momentaneamente diante da brutalidade, tanto a do assassino quanto a do Estado que o condena. 


\subsection{0 ogro}

Toda a mitologia de Le Roi des Aulnes, embora constitua um universo ficcional muito rico, está subordinada a uma lógica e intenção discursiva rígidas, posto que pretende dar conta de um problema histórico. Para que a abordagem do nazismo e da Shoah seja bem sucedida, os elementos míticos devem estar concentrados e organizados em torno de um eixo comum, para que a trama não se perca numa eventual pluralidade de referências e possibilidades - própria das narrativas mais fantásticas.

Eis, portanto, a função estrutural soberana do ogro na narrativa: ele serve como um vórtice da fabulação mítica, a partir do qual as regras do universo mágico são determinadas e incluídas na obra. Prova disso é que não há nenhum outro tipo de criatura feérica em todo o romance, nada mais é mágico ou estranho senão o ogro e tudo o que a ele se relaciona: o espaço, o tempo, os animais, as coisas, os acontecimentos. Abel Tiffauges, como protagonista, desempenha na trama uma função predominante, e por isso mais interessante, ambígua, significativa. Não podemos ignorar, contudo, que ele não é o único ogro do romance, ao lado dele estão, no mínimo, as figuras de Göring e Hitler, sem contar as demais personagens secundárias que eventualmente partilham de alguma inclinação sobrehumana.

Procuraremos demonstrar, nas páginas seguintes, quais são as especificidades deste ser mitológico e como ele é configurado na obra. De todo jeito, a questão que se apresenta aqui é delimitar que a fabulação mítica ocorre necessariamente vinculada à figura do ogro, ou seja, que é em torno deste arquétipo que toda a esfera mítica se organizará. 


\subsubsection{Etimologia}

Talvez não fosse preciso justificar a busca por uma definição específica acerca da palavra e da mitologia do Ogro; o imaginário popular já dá conta de fornecer um bom número de imagens e atribuições a esta "personagem". O fato é que sobre a palavra Michel Tournier não oferece nenhum tipo de explicação mais expressa, não faz referências etimológicas, não recupera seu sentido de nenhuma língua ou lenda particular. Simplesmente, usa a palavra Ogro para definir seu protagonista. Talvez porque de fato pressupusesse este imaginário cristalizado em seus leitores, talvez porque quisesse manter a palavra em aberto, passível de pesquisa ou de construção através de seu romance. Essa ausência de definição não seria de todo estranha se o universo romanesco de Tournier não contasse com narradores tão próximos a ele, inclinados à filosofia e à filologia, à reflexão acerca da palavra e dos significados.

Em contrapartida, Tiffauges destaca a palavra monstro de seu diário, uma palavra que ele usa para descrever a si mesmo num parágrafo - o primeiro - em que ele também se atribui uma existência atemporal, mítica, absoluta. Embora monstro não seja um sinônimo imediato de ogro, a relação está feita: "un ogre? C'est à dire un monstre féerique émergeant de la nuit des temps?" (TOURNIER, 1970, p.13). "Monstro" é talvez a primeira palavra usada para caracterizar Abel, que no princípio de seus "Écrits Sinistres" ainda não tem sua personalidade feérica completamente edificada. Sua intuição, seu autoconhecimento, contudo, indica-lhe já que sua natureza não é semelhante à da maioria das pessoas. Se ainda não sabemos o que é afinal um ogro, sabemos que a existência de Abel Tiffauges não encontra equivalente na natureza, ou melhor, não encontra incentivo na natureza. 


\begin{abstract}
Quant à la monstruosité...
Et d'abord qu'est-ce qu'un monstre ? L'étymologie réserve déjà une surprise un peu effrayante : monstre vient de montrer. Le monstre est ce que l'on montre - du doigt, dans les fêtes foraines, etc. Et donc plus un être est monstrueux, plus il doit être exhibé. (...)

Pour ne pas être un monstre, il faut être semblable à ses semblables, être conforme à l'espèce, ou encore être à l'image de ses parents. Ou alors avoir une progéniture qui fait de vous dès lors le premier chaînon d'une espèce nouvelle. Car les monstres ne se reproduisent pas. Les veaux à six pattes ne sont pas viables. Le mulet et le bardot naissent stériles, comme si la nature voulait couper court à une expérience qu'elle juge déraisonnable. Et là je retrouve mon éternité, car elle me tient lieu à la fois de parents et de progéniture. Vieux comme le monde, immortel comme lui, je ne puis avoir qu'un père et une mère putatifs, et des enfants adoptifs. (TOURNIER, 1970, p. 14)
\end{abstract}

Resta-nos verificar, através da análise da configuração da personagem, se de fato essa primeira descrição, feita numa fase mais imatura de Abel em relação à sua trajetória e consciência de si, é adequada. Eis, portanto, o motivo de recorrermos à consulta do próprio verbete: encontrar as referências subjacentes da personalidade mítica de Abel Tiffauges.

Pierre Brunel, em seu Dicionário de Mitos Literários levanta diversas definições para o verbete e indica que a etimologia da palavra "ogro" é controversa:

Bloch et Wartburg indica que a palavra aparece em $1300 \mathrm{com}$ o sentido moderno e que ela - provavelmente uma alteração da forma 'orc' do latim 'Orcus', significando 'deus da morte' e 'inferno' - teria sobrevivido nas crenças populares para chegar à lenda do ogro. Esta etimologia é apoiada pelo italiano orco = 'papão', pelo espanhol arcaico huerco = inferno, diabo" e por uma passagem da vida de Santo Eloi, morto em 659, que alude a ela num sermão onde, repreendendo aqueles que conservam velhas superstições pagãs, cita Urcus, Netuno e Diana. (BRUNEL, 2005, p. 754) 
Em seguida, Brunel assinala que a palavra ogre é rara no francês antigo, sendo empregada por Chrétien de Troyes sem, contudo, significar um monstro antropofágico.

Ainda, ele menciona uma linha de interpretação completamente diferente, que situa como referência ao ogro o radical garg, que quer dizer garganta, presente em Górgona e Gargantua. Assim, "o ogro confunde-se com o 'Orcus subterrâneo, com o Ocidente devorador de Sol'. Ele seria a valorização negativa de Gargan-Gargantua, o Sol céltico. Seria o sentido ativo de engolir, comer, o pai de todas as Górgonas. (...) O elo entre o ogro e a idéia de devorar, engolir e as trevas mortais, impõe-se".

Além da etimologia, Brunel cuida de reunir as diversas manifestações do ogro nas culturas mais variadas. $\mathrm{O}$ excerto que segue é o parágrafo em que ele procura organizar e encadear as diferentes representações:

O Crono grego, tornado famoso com o quadro de Goya, Saturno devorando os filhos, é o símbolo do tempo destruidor. Ele é o protótipo divino do ogro. O Orcus subterrâneo que devora o sol e os mortais está figurado nas pinturas funerárias das tumbas etruscas sob a forma de um gigante barbudo e hirsuto. $O$ ogro está ligado a essas divindades pagãs que evocam a morte. Seu aspecto de gigante trai-lhe a origem sobrenatural. Ele traz ainda à lembrança aqueles Titãs, filhos do Céu e da Terra que, nas origens do mundo, se revoltaram contra os deuses. O ogro canibalesco aparece como o "herdeiro desses gigantes insolentes, detratores dos espíritos celestes que reinavam antes do dilúvio". "Já estava lá há mil anos, há cem mil anos, diz o ogro do Rei dos elfos(sic), evocando aquelas origens imemoriais. $\mathrm{O}$ parentesco do ogro com os Ciclopes - gigantes antropofágicos dos quais Polifemo, a figura que devora os companheiros de Ulisses, é o protótipo mais conhecido. (BRUNEL, 2005, p. 756)

Passeando por descrições que aproximam o ogro de um gigante, ou de um dragão e mesmo de um monstro marinho, Brunel chega à formulação da pergunta que interessa sobremaneira a esta pesquisa: "esses diferentes avatares do ogro no folclore e nos contos levam-nos a questionar sua natureza: seria divina, apesar de 
maléfica? Animal, apesar de ligada a forças sobrenaturais? Ou humana, apesar de seu canibalismo excluir qualquer sociedade?" (BRUNEL 2005, p. 756).

Evidentemente, uma pergunta formulada nesses termos visa menos obter uma resposta do que demarcar o campo de conhecimento em que o objeto deve ser situado. Nem as investigações etimológicas, nem a consulta a todo folclore e lenda popular dão conta de uma definição ou da fixação da figura do ogro. De todo modo, as definições todas corroboram com a representação que Tournier deu ao mito, elas reiteram várias das características de Abel, ou parecem inspirar passagens de sua trajetória. O que nos cabe, agora, é analisar especificamente as características do ogro, ou dos ogros, tais como Michel Tournier as (re)escreveu.

\subsubsection{Figurações do ogro: Tiffauges, Göring e Hitler}

Como dissemos, a figura do ogro determina e orienta toda a estrutura mítica do romance, e embora a etimologia e a tradição literária abram caminho para uma compreensão mais precisa a respeito desse arquétipo, desse modelo de existência que permeia as personagens mais importantes, é preciso analisar cada um dos casos para decantar as especificidades de cada um deles. Entender que a monstruosidade não é exclusiva ao protagonista, e que cada personagem exerce sua "ogridade" de maneira particular, significa avançar nas camadas cognitivas da obra e decifrar um pouco mais a intenção crítica do autor. Sendo assim, identificamos nos três ogros do romance as passagens e características que tornam suas figurações ora semelhantes e ora diferentes. 
Abel Tiffauges, o ogro fórico

O primeiro capítulo desta dissertação foi quase inteiramente dedicado a mostrar como a escrita do diário "Écrits Sinistres" viabilizou e sustentou dialeticamente a personalidade ogra de Abel, pautando a construção dessa personalidade no exercício mnemônico e na interpretação do presente à luz dessas lembranças então recuperadas. Todo o processo de configuração do Ogro é apenas um primeiro passo em toda a trajetória da personagem. Uma vez que situamos o mecanismo da inversão e o hibridismo mitológico que superestrutura a narrativa, podemos avançar e discutir afinal a trajetória de Abel como Ogro "consolidado", atuando no mundo e dele recebendo sinais como resposta.

As obras de Michel Tournier via de regra estabelecem dualismos entre o mundo real e o mundo mágico, ou o mundo mítico, de modo que um dependa do outro para garantir sua existência plena. Assim, uma criatura fantástica, folclórica, como é o caso do ogro - em especial o ogro Abel Tiffauges - existe necessariamente em contraste com todo o resto das pessoas.

Arlette Bouloumié afirma que o ogro, em Tournier, é a representação do homem caído, culpado de um crime original, ao mesmo tempo cruel e sofredor em sua solidão e sua separação do feminino (BOOULOUMIÊ, 1988, p. 85), isto é, ele entra inequivocamente no acervo mitológico do escritor e figura um desdobramento do mito adâmico. Ser herdeiro do drama da criação, contudo, implica que o caráter trágico da condição humana inteira se exprima através dele. A personagem se inscreve portanto num espaço ambíguo, dicotômico e conflitante, pois quanto mais feérica for a natureza de sua identidade, mais comprometida com a condição humana ela parece estar, ou, em outras palavras, quanto mais aguçada for sua 
vocação sobrehumana, mais ela terá acesso aos símbolos que revelam e impulsionam a existência dos homens.

Em Le Roi des Aulnes, a "queda" está associada à divisão primordial entre o ser masculino e o feminino, que por sua vez tornaram-se eles mesmos fundadores de dois legados, dois arquétipos: o nômade e o sedentário. Quando Tiffauges afirma que o casamento é uma tentativa derrisória de restituir o Adão original (TOURNIER, 1970), é porque a cisão primordial determinou que o homem e a mulher compõem, juntos, uma união necessária à continuidade da espécie, mas, ao mesmo tempo, uma dualidade incompatível e insuficiente. É assim que Abel entende-se como um ogro, pela primeira vez, ainda nos braços de sua amante Rachel. Quando ela Ihe diz "tu n'es pas un amant, tu es un ogre." (TOURNIER, 1970, p. 21) ela denuncia sua inaptidão natural à entrega amorosa e sexual, sua inadequação à formula trivial homem e mulher. Com efeito, a vocação tiffaugeana de restituir o mito adâmico capitula à foria e à inversão benigna, nunca às formas ordinárias de compreensão e manutenção da vida. Michel Tournier, certa feita, respondeu à questão "13 "o que é um ogro?" da seguinte maneira:

\begin{abstract}
Un ogre, dans la vie comme dans la littérature, c'est un type d'homme jovial, gros mangeur, mais finalement assez chaste et se répandant en plaisanteries scatologiques. Gargantua et Pantagruel sont des ogres. Ils parlent beaucoup de «torche-culs» mais rarement d'exploits sexuels. Ce ne sont pas de génitaux, ils appartiennent franchement au genre anal. »
\end{abstract}

Com essa declaração, o escritor não apenas situa Abel numa tradição folclóricoliterária específica, como corrobora com o que se acabou de afirmar neste trabalho. No mais, a atrofia da capacidade amorosa e sexual é apenas a primeira instância de

\footnotetext{
${ }^{13}$ TOURNIER, M. In: Le nouvel observateur, 30 novembre 1970. «Portrait d'un ogre » apud BOULOUMIÉ, 1988, P. 94.
} 
uma monstruosidade que se desenvolverá num campo especialmente simbólico e discursivo. Isso porque o mecânico de Porte-des-Ternes, sendo tão culto e inclinado à observação, sendo, aliás, particularmente muito pacífico, abdica de uma violência que costuma ser inerente aos ogros. Cada uma de suas perversões, como veremos, são manifestações abrandadas dos impulsos glutões e devastadores dos ogros lendários.

As brincadeiras escatológicas que Tournier menciona na referida entrevista projetam-se, no caso de Abel, nas passagens em que ele, assim como Nestor, diverte-se em observar as formas extravagantes dos dejetos: "je regarde attendri ce beau poupon dodu de limon vivant que je viens d'enfanter, et je reprends goût à la vie" (TOURNIER, 1970, p.124). Nas palavras de Bouloumié, "il poursuit la rêverie enfantine de la naissance anale, "la 'grande béatitude fécale' (BOULOUMIÊ, 1988, p. 236) dans laquelle il vit manifeste une tendance régressive au stade anal" (BOULOUMIÊ, 1988, p. 94).

A autora ressalta o vampirismo como uma segunda transgressão que o predispõe a tornar-se um ogro e aparece quando Pelsenaire obriga-o a lamber 0 joelho machucado e cheio de sangue. Contudo, na ocasião da morte de Arnim le Souabe, um dos meninos internos na napola cujo corpo explode por causa de uma mina e faz com que Tiffauges seja coberto de sangue, seu vampirismo ressurge com uma intensidade inédita. A reação de Tiffauges a esta tragédia é de um desequilíbrio emocional extremo: ele fica transtornado, embriagado, febril, submerso em "un excès de joie, une joie d'une insuportable violence, une brûlure plus cruelle et plus profonde que toutes celles que j'avais subies précédement... mais une brulûre de plaisir" (TOURNIER, 1970, p. 347). 
Abel passa por uma etapa que ele mesmo chama de fagie, durante a qual ele consome carne crua em grandes quantidades: "Voilà monsieur Tiffauges qui revient du marché avec sa provision de chair fraîche. II va maintenant s'enfermer dans le noir pour manger tout ça. II y a des choses qu'on ne fait pas au grand jour, pas vrai ?" (TOURNIER, 1970, p.180). É bastante fácil perceber os resquícios de uma identidade primitiva e animalesca nessa fase digestiva da personalidade monstruosa. Acontece, entretanto, de seu gosto pela carne crua ser paulatinamente aplacado enquanto ele intensifica o convívio com as crianças das redondezas. Então, seu apetite ogro encontra uma expressão melhor e mais complexa, que reúne uma certa pedofilia ${ }^{14}$ e uma inclinação antropofágica muito bem marcada, que implicará, afinal, na experiência fórica.

Tout se passe comme si le contact avec des enfants apaisait ma faim de façon plus subtile et comme spirituelle, une faim qui aurait évolué du même coup vers une faim plus raffinée, plus proche du cœur que de l'estomac. (TOURNIER, 1970, p.183)

Este é certamente o aspecto mais relevante da faceta ogra de Abel: sua vocação devoradora combinada ao fascínio obsessivo que ele nutre pelas crianças. A voracidade de sua transgressão manifesta-se sobretudo numa fase fotógrafa em que ele se sente particularmente satisfeito tendo "mon rollei pendu en sautoir à mon cou et bien calé entre mes cuisses" (TOURNIER, 1970, p.144). A analogia com o órgão sexual é evidente, é explicitada pela própria personagem: "je me plais ainsi équipé d'un sexe énorme, gainé de cuir, dont l'œil de Cyclope s'ouvre comme un éclair quand je lui dis 'Regarde !' et se referme inexorablement sur ce qu'il a vu.

\footnotetext{
${ }^{14}$ Michel Tournier recusa terminantemente esta interpretação. Collin, em seu artigo "Images de Michel Tournier" (1990), demonstra como o escritor, sob o risco de contradizer sua teoria a respeito da liberdade absoluta de interpretação por parte do leitor, refuta qualquer leitura que considere Abel um pedófilo genuíno, dentro de uma tipificação criminosa nossa contemporânea.
} 
Merveilleux organe, voyeur et mémorant" (TOURNIER, 1970, p.144). A competência ao ato sexual, frustrada, desloca-se como pulsão, como deleite do observador: "Mettre des enfants en cage... mon âme ogresse y trouverait son compte" (TOURNIER, 1970, p.131). Abel estabelece uma relação direta entre enxergar as crianças, capturar suas imagens e saciar-se emocional e sexualmente. Essas fotos, bem entendido, não constituem um material pornográfico; se elas conduzem a algum tipo de gozo, é porque atuam, sempre simbolicamente, em favor da possessão:

C'est un mode de consommation auquel on recourt généralement faute de mieux (...) Le photographe est avare, avide, gourmand, centripète. (...) Ne disposant pas des pouvoirs despotiques qui m'assureraient la possession des enfants dont j'ai décidé de me saisir, j'use du piège photographique. (...) L'envoûtement et ses pratiques exploitent déjà la possession mi-amoureuse mi-meurtrière du photographié par le photographe. (TOURNIER, 1970, p. 145)

As relações entre o deleite visual e o sexual não esgotam a fase da fotografia para Abel, pois a esta equação soma-se a representação antropofágica, a possibilidade de assimilação feiticeira do ser desejado reconhecida em toda sua vocação ritualística e sobrenatural. Estamos próximos, assim, de um aspecto frequentemente atribuído ao ogro na tradição mítica e cultural: o devorador. Representado muitas vezes como um ser monstruoso que engole o sol, as rochas, as pessoas, o ogro devorador está em Tiffauges numa versão atualizada e refigurada de maneira a garantir a manutenção do desejo antropofágico desvinculando-o todavia do ato antropofágico propriamente dito.

Pour moi, l'aboutissement de l'acte photographique sans renoncer aux prestiges de l'envoûtement va plus loin et plus haut. II consiste à élever l'objet réel à une puissance nouvelle, la puissance imaginaire. L'image photographique, cette émanation indiscutable du réel, est en même temps consubstantielle à mes fantasmes, elle est de plain-pied avec mon univers imaginaire. La photographie 
promeut le réel au niveau du rêve, elle métamorphose un objet réel en son propre mythe. (TOURNIER, 1970, p. 145)

O resultado desse novo arranjo apresenta-se aliás em dois sentidos: ao mesmo tempo em que sustenta o anseio glutão do ogro, a refiguração provoca uma certa descaracterização do mito quando o insere na civilização. Abel, anarquista convicto, recusa e critica a maior parte dos preceitos culturais, sobretudo os franceses. Isso não o impede, contudo, de viver dentro de uma sociedade organizada, com princípios morais, éticos e culturais aos quais ele adere em parte - a ponto, por exemplo, de escolher uma posição política específica.

Quando lança mão de estratégias tecnológicas para saciar seu desejo mais profundo de domínio e degustação, quando analisa filosoficamente as instâncias de uma pulsão primitiva e sombria, ele está, de certo modo, apequenando-se diante de sua realidade histórica. Disso decorre que Abel não é um ogro tão-somente, ele é um ogro inserido em um contexto, em uma trama, em esquemas que engendram e moldam irreversivelmente a vida do homem moderno: um ofício, uma casa, uma cidade, uma lei. Submetida a cada uma dessas instâncias, a faceta monstruosa do garagista não pode ser nada além disso, uma faceta, uma manifestação de uma porção genuína de sua personalidade.

É preciso ressaltar que a refiguração mítica do ogro, e seu consequente apequenamento diante da dimensão histórica, não cria uma versão conservadora ou frágil do ponto de vista político. Atribuir ao olhar a capacidade de captura e assimilação do objeto de desejo pode desembocar numa pertinente discussão acerca da liberdade corporal, passando pela evidência do potencial transgressor do desejo (seja ele de natureza sexual ou não). Em seu ensaio 8 1⁄2 de Fellini, Schwarz 
escreve uma passagem belíssima a respeito do alcance progressista da postura contemplativa.

\begin{abstract}
A postura contemplativa - os olhos buscam seu prazer onde ele esteja - pressupõe uma república satisfatória, que não existe. Prova é que ao corpo não se permite a poligamia ativa e farta permitida aos olhos, cujo democratismo natural, cuja capacidade imediata de interesse e simpatia não derrubam, por sua vez, as diferenças sociais. Os olhos são progressistas enquanto o corpo obedece ainda uma legislação retrógrada. (SCHWARZ. 1981, p. 196)
\end{abstract}

Se, a respeito do filme, cabe dizer que a "república satisfatória" que garantiria ao corpo a mesma liberdade do olhar não existe, estendemos ao romance a seguinte reflexão: todo o romance está organizado em torno de questões corporais, sensíveis, sexuais. Seja por conta da constituição física do próprio Abel, seja porque a foria se realiza através da união dos corpos de um adulto e uma criança, visando restituir uma condição primordial igualmente física. Boa parte das críticas que Tiffauges faz em relação ao nazismo tem a ver com o alistamento de jovens, com a modelação de seus corpos para a guerra. Sendo assim, há, no romance, um equivalente dessa legislação retrógrada, supercontroladora, de que fala Schwarz. Se ela não se manifesta em questões políticas explícitas, é porque manteve a dimensão histórica subjacente à mítica. Mas ela se coloca, de um jeito ou de outro, quando Abel se entrega à observação e à reflexão enquanto o mundo começa a ruir à sua volta. Se a contemplação substitui os impulsos fágicos que o faziam devorar pedaços de carne crua, mais tarde ela será também substituída por outras práticas "ogras", entre as quais a foria se destaca.

Do ponto de vista da monstruosidade, o ato fórico compreende um avanço da vocação devoradora, posto que ao tomar uma criança nos braços, ao carregá-la, o adulto mantém a simbologia da posse, do pertencimento, da unificação de dois 
corpos em um. Não por acaso a satisfação proveniente da foria supera aquela da fase fágica ou da fase fotográfica, ela encerra afinal a refiguração que Michel Tournier propõe do mito do ogro devorador. Sendo mais sofisticada, porque sustenta-se sobre um aparato mítico muito mais elaborado, a foria constitui a radicalização da personalidade ogra de Abel pois radicaliza a simbologia da deglutição.

O que faz de Abel um ogro tão particular é que quanto mais suas características monstruosas se acentuam, mais ambígua se torna sua situação em relação ao ser simbolicamente devorado. Posto que o mal que ele causa é quase sempre de natureza simbólica, Ihe é dada a possibilidade de cumprir um ato benigno ao mesmo tempo, e também simbolicamente. É esse tipo de ambiguidade que conduz, por exemplo, toda a trajetória de Abel como ogro de Kaltenborn. O interesse pessoal de Abel nas crianças, seu fascínio e mesmo seu senso de proteção e conservação de sua inocência paradoxalmente o faz trabalhar numa napola recrutando os meninos da região. Ele não apenas é refratário à toda ideologia nazista, como também é crítico convicto - porém silencioso - de suas práticas. Sua aparente (e parcial) conivência com o sistema de formação que a napola engendra é determinante para que ele se consagre popularmente como o ogro de Kaltenborn, como se esta fosse sua pequena reserva, dentro de cujos limites ele espreita e toma para si as crianças.

La semaine avait été exceptionnellement fructueuse, et Tiffauges s'en revenait du village d'Erlenau où il avait obtenu que tous les garçons de la commune nés en 1931 fussent présentés à l'Alei.(...) II mettait pied à terre dans la cour, quand l'Alei lui fit signe par la fenêtre de son bureau. II lui tendit une feuille de papier de mauvaise qualité sur laquelle un texte était reproduit grossièrement à la machine à polycopier.

Cet avertissement s'adresse à toutes les mères habitant les régions de Gelhenburg, Sensburg, Lötzen et Lyck! 


\section{Prenez garde à l'ogre de Kaltenborn!}

II convoite ses enfants. II parcourt nos régions et vole nos enfants. Si vous avez des enfants, pensez toujours à l'Ogre, car lui pense toujours à eux! Ne les laisse pas s'éloigner seuls. Apprenez-leur à fuir et à se cacher s'ils voient un géant monté sur un cheval bleu, accompagné d'une meute noire. S'il vient á vous, résistez à ses menaces, soyez sourdes à ses promesses. Une seule certitude doit guider votre conduite de mères : si l'Ogre emporte votre enfant, vous ne le reverrez jamais ! (TOURNIER, 1970, p. 394)

As semelhanças entre a descrição feita e o espectro da lenda do Rei dos Álamos são inequívocas; o comportamento e a função de Tiffauges em toda a região de Kaltenborn o aproximam muito daquela figura sombria. Se diante da comunidade sua porção maligna, usurpadora e assassina de crianças se cristaliza, dentro dos portões da napola ele se diferencia e afasta-se cada vez mais deste "culto demoníaco" que oferece crianças em sacrifício. Todo o capítulo "l'Ogre de Kaltenborn", assim, constitui uma etapa complexa na trajetória da personagem, pois quanto mais ela se aproxima de cumprir seu destino, mais próxima ela também fica de toda a malignidade que se dispõe a combater.

O fascínio que as crianças exercem sobre Tiffauges, aliás, é o equivalente benigno, digamos assim, do fascínio que a morte the causa. Arlette Bouloumié assinala a necrofilia da personagem, que gosta de observar corpos inertes, adormecidos ou hipnotizados, que ama contemplar a imobilidade (BOULOUMIÊ, 1988, p. 95). No velório de Hellmut, o narrador diz que "la mort donnait à sa chair une plénitude qu'elle n'avait jamais connue à l'étati vif" (TOURNIER, 1970, p. 520).

Tiffauges não ama a morte simplesmente, basta lembrar sua reação face à morte institucionalizada pelo Estado através da pena capital, ou a morte abominável e crua impingida aos prisioneiros dos campos de concentração. Antes, a morte que the fascina é semelhante àquela representada pelo espectro dos álamos que leva 
consigo a alma do menino; Tiffauges aprecia a morte ritual, iminente e oscilante, a morte que seduz e é seduzida pela carne fresca: "Quand je dis : «j'aime la viande, j'aime le sang, j'aime la chair ", c'est le verbe aimer seul qui importe seul. Je suis tout amour" (TOURNIER, 1970, p.112).

$\mathrm{O}$ ato meurtrier vem acompanhado do amor pelo corpo, pela carne, ele pertence a um rito antropofágico de contemplação e assimilação. A morte, para ele, é como um oposto simétrico, um equivalente negativo da vivacidade das crianças que ele ama e deseja à sua maneira. $O$ verso final da balada de Goëthe, cuja tradução Tournier contesta em Le vent paraclet, paira justamente entre a via dupla do fascínio e da morte, a atração pela carne e o amor:

La passion pédophile du roi des aulnes est certes amoureuse, charnelle même. (...) Le vers de la ballade le plus ambigu et plus difficile à traduire est évidement le fameux: "Ich liebe dich. Mich reitz deine schöme Gestalt " que l'on affadit traditionnellement en traduisant: "Je t'aime. Ton doux visage me charme». Alors qu'un mot à mot autoriserait : " Je t'aime, ton beau corps m'excite "

Mais ce serait à coup su outrer l'intention de Goethe. C'est pourquoi dans la traduction que j'ai fait figurer en appendice du roman, je propose pour ce vers : « Je t'aime. Ton beau corps me tente. » (TOURNIER, 1977, p.120-1)

A vocação devoradora, sobretudo em sua expressão fórica, simboliza o fascínio pelo infante tanto quanto simboliza sua aniquilação. Mais ainda, ela compreenderia a plataforma através da qual o ogro atinge a plenitude perdida, o estado de inocência metafísica, anterior à experiência do bem e do mal. Tal é a aspiração de Tiffauges quando propõe-se a restituir o Adão original, ele busca tocar o estado de consciência cristalino, livre, pleno. Nas palavras de Bouloumié,

si l'ogre veut dévorer l'enfant, c'est symboliquement qu'il cherche à s'identifier à lui en se l'incorporant (...) il aspire à l'innocence, à la puissance vitale de l'enfant. L'ogre est présenté comme un être déchiré, torturé par une angoisse métaphysique (BOULOUMIÊ, 1988, p.100). 
Mais uma vez, o aspecto do ogro primário e monstruoso encontra uma projeção simbólica em Tiffauges e, de certa forma, um abrandamento. A morte simbólica não é a morte de fato, Abel não assassina nenhuma criança ao carregá-la - diferente do espectro lendário. A aniquilação simbólica que ele promove ocorre muito mais no sentido de consumar o pertencimento, de trazer para si a existência daquela criança, embora, no momento derradeiro de sua trajetória, Abel inverta a situação e ofereça a própria vida em sacrifício pelo pequeno Éphraïm.

Em suma, dois traços fundamentais que constituem a controversa figura do ogro, nas diferentes tradições, estão presentes e ligadas na personagem do garagista de Porte-des-Ternes. Como os demais ogros, Tiffauges tem o apetite da carne fresca, também ele flerta com a morte. Há, finalmente, um terceiro: a relação entre o ogro devorador e o tempo, evocada pelo mito de Cronos.

Se o mito, por excelência, é aquilo que paralisa e nega o tempo, que dizer acerca de um ser mitológico que devora os próprios filhos e assim, devora simbolicamente o Tempo? A relação entre o ogro e a atemporalidade está previamente consolidada, mas assume, nessas circunstâncias, uma dimensão muito mais nítida. Tiffauges usa a foria para restituir o Adão original, ou seja, pela assimilação simbólica do infante, ele procura devorar o tempo, superá-lo, e tocar aquele átimo de eternidade que resta aos mortais. Curiosamente, não é a sua mortalidade que está em questão, mas a nossa. O final da trajetória de Abel indica que ele, deixando-se guiar pelo pequeno Éphraïm, salvando-o e executando quase literalmente a cena mitológica de São Cristóvão, está de fato profundamente comprometido com o destino humano. Margaret Sankey, ao ocupar-se da personalidade feérica de Tiffauges, pondera que todos os críticos abundantemente dissertam sobre o significado tournieriano do ogro, 
focando sua tradicionalidade como monstro amante de carne fresca, símbolo de força cega e devoradora: "avaleur et cracheur, lieu de métamorphoses d'où la victime doit sortir transfigurée, il n'est pas sans lien non plus avec la nature du temps, tout à fois créateur et destructeur" (in BOULOUMIÉ; GANDILLAC, 1990, p. 337). Ela afirma, ainda que o próprio ato de engolir não está sempre ligado à deterioração, ele também, muitas vezes, confere um valor ou uma sacralidade ao objeto engolido de maneira que ele esteja paradoxalmente ligado à lenda de São Cristóvão, pois assim como a deglutição preserva o herói engolido, a travessia nos ombros do gigante salva os atravessados. A conclusão de Sankey sobre a monstruosidade de Abel é que ele incorpora em si todos os aspectos e assim, seu apetite de carne fresca e seu voraz consumo de signos e de símbolos encontram-se invertidos na cena final em que o turbilhão o consome, executando uma espécie de eufemismo da morte. "Escritor e leitor", ela continua, "Tiffauges faz de sua função fórica um verdadeiro desdobramento ao infinito" (in BOULOUMIÊ; GANDILLAC, 1990, p. 338, tradução nossa).

A beleza dessa formulação de Sankey está na aparente simplicidade com que ela promove Tiffauges de um estatuto primário de personagem fictícia, de um ogro em busca de um significado para si próprio, a um estatuto mais sofisticado de uma personagem que busca o significado tout court. Isto é, a busca pelo destino é a busca pela própria identidade; Abel quer encontrar a si mesmo em sua trajetória, e a lógica do destino não poderia ser outra: apenas no cumprimento da profecia Abel é quem ele pretende ser durante toda a narrativa. A ironia de sua situação é que sua procura o conduz até o coração de uma guerra que profanou tudo que lhe é caro, ele só pode encontrar a si mesmo no ponto nevrálgico de seu oposto, na recusa de si próprio. 
Se numa primeira leitura define-se que a monstruosidade de Abel implica que ele seja um devorador de carne crua, depois um portador de crianças e em seguida o executor do gesto primordial, é razoável reconhecer também que Abel devora e porta consigo os sinais do destino para compor, ao final de sua trajetória, a equação derradeira que une as duas pontas da história. Todas essas etapas da conquista do significado, portanto, são indícios de que entre o non-sense absoluto e a busca delirante por um sentido, Abel opta por esta última. Sua monstruosidade se acentua à medida que ele resiste ao desespero, "la seule réponse authéntique au non-sens de la vie" (TOURNIER, 1970, p. 87)

Göring, o ogro militar

O capítulo sobre o ogro de Rominten, negligenciado por alguns críticos, contém a passagem de Abel Tiffauges pela reserva de Rominten, espécie de retiro do segundo homem mais poderoso no Reich, o marechal Göring. Em relação à trama como um todo, o episódio da reserva de Rominten desempenha de fato um papel secundário, não oferecendo nenhuma mudança ou avanço que seja profundamente significativo para a personagem. O capítulo nos interessa precisamente nessa sua relativa importância, nas coisas que ele sugere e prepara em relação às demais partes da narrativa.

A começar por sua epígrafe com o verso de Charles Perrault para refererir-se ao ogro do Petit Poucet: "il flairait à droite et à gauche, disant qu'il sentait la chair fraîche" (TOURNIER, 1970, p.262). Não se trata apenas de uma referência ao monstro, mas à caça, a sua habilidade por excelência. A epígrafe é perfeitamente 
adequada para o capítulo que introduz, tal é a atuação do ogro de Rominten em suas terras ${ }^{15}$.

A peculiaridade da narrativa opõe a esta terra magnífica e feiticeira uma descrição completamente técnica e objetiva de quem seria, afinal, o ogro soberano de Rominten: "En 1936, le Feldmarshall Hermann Göring qui avait la haute main sur Rominten au double titre de président du gouvernement de Prusse et de grand veneur du Reich" (TOURNIER, 1970, p.266).

No romance, não há nenhum registro da atuação desse alto marechal nazista nas questões que fizeram dele um homem poderoso; mas acompanhamos o que seriam seus momentos de entrega aos prazeres e passatempos em sua casa de campo. Rominten é, portanto, o cenário em que o marechal do Reich pode exercer à vontade suas inclinações e desejos e, por isso, sua configuração ogra fica subordinada a este lugar específico. Sabemos, por exemplo, que sua sala está repleta de cabeças de veados, cujas galhadas são como troféus; temos que seus aposentos eram decorados com uma "estrita rusticidade" e que sua mesa era farta. Göring, com seus quase cento e trinta quilos, aproxima-se do ogro glutão, caçador, animalesco, primitivo.

Mencionamos anteriormente ${ }^{16}$ que o narrador descreve o comportamento dos javalis de maneira a criar uma analogia entre eles e o próprio marechal, que possui uma personalidade selvagem e assassina. Com efeito, o uso dos animais para metaforizar a natureza das personagens nos mostra que Göring e Tiffauges, embora sejam ogros e compartilhem algumas inclinações, são essencialmente incompatíveis entre si. Quando pedem ao marechal que expulse os javalis por conta da destruição

\footnotetext{
${ }^{15}$ Ver "os espaços mágicos".

${ }^{16}$ Ver "Hibridismo homem-animal".
} 
que provocam, ele não apenas decide reservar uma zona especialmente para eles como determina que eles serão alimentados com a carne de cavalos mortos.

II avait ordonnée qu'on adoptât la solution inverse, celle qui consistait à rendre le fond oriental de Rominten si délectable aux sangliers qu'ils y demeurassent fixés. On avait imaginé pour cela de les nourrir avec des cadavres de chevaux d'équarrissage qu'on abattait à la place même où les cochons viendraient les dévorer.

Tiffauges ressentit comme une épreuve cruelle, mais sans doute chargée de signification - et donc bénéfique - ces opérations d'abattage où on lui imposait le rôle de tueur. (...) Tiffauges défaillait de dégoût en observant ces opérations grossières qui évoquaient quelque assassinat gigantesque, perpétré au coin d'un bois, d'autant plus qu'il avait vite détecté l'affinité profonde qui le liait au cheval, animal phorique par excellence, et qui conférait un trait suicidaire à ses tueries. (TOURNIER, 1970, p. 268)

Somada ao apetite e personalidade expansiva, que contribuem com sua monstruosidade, está sua capacidade aguçada de analisar as fezes dos veados que caça. A naturalidade com que ele reconhece e aproveita as informações de suas presas através de seus dejetos aperfeiçoa seu desempenho como caçador, ou seja, a constituição da personalidade ogra de Göring conjuga pelo menos dois elementos também presentes na "ogridade" de Abel, mas de modo a formar uma personagem muito mais agressiva, animalizada, perigosa. Abel, evidentemente, reconhece em Göring a natureza monstruosa e as semelhanças que aproximam o militar de si e mesmo de seu amigo Nestor. Deste modo, Göring representa uma versão peculiar do ogro, um ser que compartilha de perversões e vocações com Tiffauges mas que as exerce de uma maneira completamente diferente - de maneira indireta, o texto formula uma espécie de complementação mítica e psicológica para sugerir que tipo de mentalidade poderia inventar e executar um genocídio.

Não há nenhuma menção explícita quanto à participação de Göring nos acontecimentos da Segunda Guerra ou da Shoah, embora saibamos que ele esteve desde cedo bastante envolvido. Göring é "apenas" o ogro de Rominten, um exímio e 
ávido caçador, salvo na passagem em que Tiffauges é chamado para explicar um contratempo que tivera com a manada de búfalos. Nessa ocasião, Abel é recebido por Göring e seus convivas, nazistas como ele.

II fallut que Tiffauges précisât le lieu et l'heure de la rencontre, le nombre des aurochs, la direction d'où il paraissaient venir, la réaction des chevaux, sa propre attitude - et à chaque nouveau détail, le grand veneur hurlait de rire en se tapant sur les cuisses. Puis on le plaisanta sur ses lunettes, suggérant qu'à travers ses verres grossissants il avait peut-être pris quelques lapins pour des taureaux géants, et Tiffauges découvrit pour la première fois lune des marottes des maîtres du $1 \mathrm{II}^{\mathrm{e}}$ Reich, cette intelligence, l'étude, la spéculation, bref le Juif. (TOURNIER, 1970, p.274)

Essa única e breve observação a respeito da repulsa dos nazistas por aquilo que os judeus representavam indica algumas coisas. A começar que toda a fabulação, toda a inserção de um universo romanesco fantástico não implica, em absoluto, que a narrativa ignore aspectos fundamentais da ideologia nazista, e que mesmo uma leitura mítica do Reich é capaz de destituir o nazi-fascismo de qualquer formulação positiva. Em outras palavras, não se trata de separar nazistas e judeus entre selvagens e intelectuais e disso deduzir um ódio irracional, uma repulsa automática. Vimos como, ao longo de todo o romance, Abel escapa a qualquer deslumbramento pela civilização e, mesmo inclinado ao pensamento crítico e à filosofia, ele também se mostra um grande amante do mundo natural. A animalidade dos nazistas, no entanto, inclui uma brutalidade que é estranha a Abel, e que demonstra não um ódio imediato ao judeu propriamente - posto que Abel não é judeu - mas a qualquer símbolo e representação da própria intelectualidade, do esclarecimento, da especulação.

Se há no nazismo um lado ritual profundamente estético, impecável, ardiloso e sedutor, certamente ele não está ligado à representação do ogro de Rominten. Antes, o militar é parcialmente descolado de sua patente para ser figurado como um 
ogro, como um monstro enorme, temido, feroz, bestial. Nesse processo, ele ilustraria então as práticas animalescas e assassinas do nacional-socialismo que Tournier interpreta como a faceta obscura demoníaca que se procurava escamotear.

Quando diz que os convivas do marechal recusam os sinais de intelectualidade, o narrador nos mostra que não Ihe escapa a força visceral com que os judeus foram atacados, como foram destituídos de sua humanidade e escorraçados por sua identidade; e não porque quer justificar a sanha nazista através desse apelo primitivo, mas porque proferindo essa observação pontual, ele indica que há uma selvageria no racismo dos nazistas que fica aquém da explicação e especulação: ela é oriunda de um reduto puramente animalizado.

Göring sugere uma profundeza obscura da alma, uma vocação assassina e debochada, que exige para si as melhores presas e as melhores oportunidades de aniquilar a vida, que reduz a morte a um jogo, a um saciamento dos apetites mais primários. Opõe-se, portanto, a toda a refiguração do ogro mítico que existe em Abel, para quem, como dissemos há pouco, a morte é ela mesma um ritual e um símbolo, uma travessia metafísica e religiosa.

A segunda observação vem no sentido de completar o que foi dito no começo desta análise a respeito do papel secundário deste capítulo. Do ponto de vista do encadeamento das ações, todo o texto de "L'ogre de Rominten" aproxima Tiffauges da napola, esta sim, fundamental para sua trajetória pessoal. Mas em si, este capítulo é mais importante porque pontua e ratifica a essência crítica da obra.

Do ponto de vista da Shoah, da ascensão do nacional socialismo e de toda sua solenidade, este é um capítulo que se apresenta audacioso e detrator, porque traz à tona algo que há muito é gestado no romance: a figuração monstruosa do militar. 
Como dissemos, Göring não é uma personagem puramente fictícia, seu nome e patente são reais, remetem de fato ao segundo homem mais poderoso do Terceiro Reich. Toda a fabulação em torno de sua figura, portanto, visam estimular uma releitura, ou melhor, um desvelamento de uma natureza ogra que o liga à essência do nazismo.

Tout homme doit savoir qu'en revêtant volontairement un uniforme quel qu'il soit, il se désigne comme créature de Mammon et encourt la vengeance des honnêtes gens. (...)

Satan (...), sa domination sur les villes se manifeste entre autres signes par les innombrables avenues, rues et places consacrées à des militaires de carrière, c'està-dire à des tueurs professionnels, bien entendu tous morts dans leur lit, parce qu'il n'y a rien de satanique sans une touche de grotesque qui est comme la griffe du Prince des ténèbres. (TOURNIER, 1970, p.106-107)

Se, até então, as críticas ao militarismo e sua ligação com forças demoníacas eram feitas de maneira genérica, a inclusão de um alto nome do regime nazista conferem outro status, não apenas veiculam a dimensão mítica com a histórica como mobilizam os recursos linguísticos para elaborar a maldade no romance. Assim, figurar o criador da Gestapo, o idealizador das câmaras de gás como um homem que tem o prazer do massacre, que é definitivamente afeiçoado à morte mais brutal e quantitativa, apresenta-se como uma alternativa de expressividade para aquilo que não se entende tampouco se formula facilmente.

Lorsque Tiffauges reprit le chemin de Rominten, le grand veneur avec ses chasses et ses massacres, ses festins de venaison et sa science coprologique et phallologique était tombé à ses yeux au rang de petit ogre folklorique et fictif, échappé à quelque conte de grand-mère. Il était éclipsé par l'autre, l'ogre de Rastenburg, qui exigeait de ses sujets, pour son anniversaire, ce don exhaustif, cinq cent mille petits garçons de dix ans, en quelque tenue sacrificielle, c'est-à-dire tous nus, avec lesquels il pétrissait sa chair à canon. (TOURNIER, 1970, p.289) 
Em última instância, o desfecho do capítulo procura explicitamente dimensionar a crueza das almas dos generais nazi, pois conclui que Göring, sendo tão brutal, apenas antecede e prepara - tanto Abel quanto o leitor - para o grande ogro do romance, o Führer.

Hitler, o ogro predador

Embora Hitler participe muito pouco da trama como personagem, diferente de seu subordinado Hermann Göring, ele permanece como uma espécie de entidade constante, uma sombra ameaçadora sob a qual a trama se desenrola. Muitos dos críticos que se dispuseram a discutir a monstruosidade de Hitler no romance acabaram por abordar o nazismo como um todo, como um mecanismo assassino. Temos igualmente a intenção de abordar, agora com mais cuidado, os meios através dos quais um programa político se configurou monstruosamente na narrativa. Entendemos, também, que a associação imediata entre Hitler e o nazismo tem sua razão de ser, mas nos propomos ainda assim tentar identificar as especificidades do ogro de Rastenburg, a personagem que foi elaborada a partir da figura histórica de Adolf Hitler.

Talvez como nenhuma outra figura da história contemporânea, o Führer teve incorporada à sua imagem uma carga de significação tão poderosa e tão imediata, a ponto de comprometer sua caracterização literária. Uma breve pesquisa em biografias e relatos, em diferentes fontes de informação, basta para indicar que o processo de mitificação da persona de Adolf Hitler, se não está perfeitamente concluído, foi ao menos parcialmente bem sucedido. Talvez seja por méritos do diretor de campanha do partido nazista, Joseph Goebbels, talvez seja pela dimensão 
do horror que ele, Hitler, tenha causado. Fato é que sobre seu nome paira, ao mesmo tempo, uma consternação que flerta com o mistério, com a interrogação para sempre insolúvel, tanto quanto paira uma espécie de esgotamento: todos sabem quem foi Hitler e o que foi que fez.

Por mitificação, nesse caso específico, compreendemos uma certa cristalização e super exposição da imagem, e, mais do que isso, um processo de acréscimo de significado e mesmo abstração da personalidade. Independente do romance de Michel Tournier, Hitler significa o mal; ele encarna, como nenhum outro ditador ou genocida, o estigma do limite insuportável e incompreensível da maldade humana.

Sendo assim, ele se presta de antemão como material de fabulação para Michel Tournier; sua persona, previamente mitificada, precisou de muito pouco para se encaixar numa trama a respeito da monstruosidade que engendrou a Shoah.

Atribuímos, portanto, a estranha ausência de Hitler na trama de Le Roi des Aulnes, em parte, a essa mitificação já devidamente estabelecida e exterior ao romance. Em parte, pois também cremos que interessa ao narrador mantê-lo a uma certa distância, interessa que sua "ogridade" se realize por processos específicos, com fins específicos.

Quando descreve e explica todo o mito adâmico, Ricœur fala muito pouco a respeito da serpente, embora, na maioria das versões, ela seja responsável por convencer Eva a oferecer o fruto proibido a Adão. A observação que Ricœur faz, de maneira sucinta, é que a serpente encarna na lenda uma porção do mal que há no próprio Adão, ela seria, portanto, um desdobramento daquilo que no homem é abjeto demais, que é inaceitável e doloroso. Como uma alteridade assustadora, a serpente pode ser maligna à vontade para que haja um mínimo equilíbrio entre os herdeiros 
de Adão e sua natureza humana (e, portanto, falha); poderia afinal o homem suportar o "peso de ser a fonte de todo o mal"? (RICCEUR, 1988, p. 194)

De maneira análoga, Hitler cumprirá o papel da alteridade assombrosa, uma versão maligna e exponenciada do ogro devorador. Em tempo: já discutimos aqui a existência de uma entidade sobrenatural, por vezes nomeada como Satan, outras como Mammon, e que por vezes se apresenta como o agente dos mecanismos de inversão. A diferença entre a entidade demoníaca, abstrata e absoluta, e a negatividade pura atribuída a Hitler é que Satan está fora dos mecanismos de malignidade, ele próprio é a malignidade que constrói o mundo. Não há nada de sobrehumano no Hitler do romance, embora ele também seja uma criatura feérica.

O ogro Hitler, temido e poderoso, é ainda um ser submetido às regras que regem o mundo, submetido aos sinais, ao destino, submetido a tudo aquilo que ele procura manipular por deleite. Assim, alteridade que ele assume é interna à esfera terrestre, é ainda pertencente à natureza humana, mesmo que ele esteja em sua zona limítrofe. No mais, se a existência de uma entidade sobrehumana que representa a malignidade absoluta (ou seja, o demônio) pode colocar em suspenso a responsabilidade humana pelas atrocidades cometidas, a existência de um homem (ou mesmo de um povo, ou um Estado) que exerça a malignidade absoluta, repõe definitivamente em mãos humanas a questão da responsabilidade e da cumplicidade diante do mal.

Entende-se melhor, sob esta perspectiva, as muitas queixas de Tiffauges acerca da sociedade francesa, da inclinação dos homens ordinários à barbárie, à covardia e à injustiça. Tournier fala longamente a respeito da facilidade com que os franceses cederam - e mesmo aderiram - às investidas do nacional socialismo quando lhes 
pareceu conveniente, do mesmo modo que cuidaram de reelaborar sua participação

no fortalecimento do Terceiro Reich tão logo ele ruiu:

\begin{abstract}
Mes parents voyaient les choses d'un autre œil. Pour eux, c'était tout un pan de leur vie qui s'écroulait. Un soir Ralph recru de chagrin et d'humiliation eut dans le petit train la surprise de sa vie. Je le vois encore rentrant à la maison et s'exclamant avant même de renfermer la porte : «j'ai voyagé avec le colonel R. ! Devinez ce qu'il m'a dit ! j'en suis complètement médusé. Il est venu à moi, il m'a tendu la main et il a prononcé très fort pour être entendu d'une partie de voyageurs : 'Eh bien Tournier, je commence á vous comprendre! Oui, je les trouve très bien moi vos Allemands! Parce que maintenant qu'ils sont là, c'est bien fini, hein, le Front populaire, les communistes, les juifs, les pédérastiques, les surréalistes, les cubistes ! Terminé ! Maintenant, tout le monde au pas. Une, deux, une deux! Et d'ailleurs, n'est-ce pas, ils sont les plus forts. Pour avoir vaincu aussi vite l'armée française, il faut qu'ils soient invincibles. Alors ? » (TOURNIER, 1977, p. 77)

En vérité la Résistance n'est devenue un phénomène d'ampleur nationale qu'après le départ des Allemands. Pendant l'occupation elle ne fut le fait que d'une infime minorité de héros que leur courage vouait au massacre et que leur désintéressement devait détourner de la course aux places à prendre après la Libération. Participer activement à la Libération et se prévaloir d'y avoir participé impliquent des psychologies fort différentes, voire incompatibles. Les authentiques résistants furent souvent noyés, submergés, écœurés par l'explosion du mythe de la Résistance après la Libération, lequel finit par faire croire que les jeunes Français entraient dans la Résistance entre 1940 et 1944 comme on fait son service militaire. Bel exemple d'auto intoxication de tout un pays concernant une période peu glorieuse de son histoire. (TOURNIER, 1977, p. 80)
\end{abstract}

No romance, o incômodo do escritor em relação a seus compatriotas parece encontrar expressão sobretudo na cena do enforcamento, já mencionada neste trabalho. Se a evocamos novamente, é para completar as observações a respeito dela, e encaixá-la nessa inquietude, nessa desconfiança irredutível que o narrador, assim como o próprio autor, tem em relação à natureza humana.

Enfim, se isolarmos as aparições expressas de Hitler no texto, percebemos que, além de raras e espaçadas, elas estão sempre ligadas a um ato discursivo, a uma comunicação que ele faz dirigindo-se aos subordinados e à população. Sua 
presença constitui, paradoxalmente, sua ausência; a "pessoa" de Hitler interessa muito menos do que a fala que ele trouxe ao mundo e, por isso, no romance, sua individualidade e subjetividade se desintegram e cedem espaço para manifestações meramente técnicas e estratégicas em relação à guerra ou profundamente fabulosas e míticas, relacionadas à aniquilação mais atroz:

- Vous ne savez pas que le 20 c'est l'anniversaire de notre Führer ? Chaque année la nation allemande lui offre en cadeau d'anniversaire toute une génération d'enfants ! (TOURNIER, 1970, p. 317)

« Désormais, avait dit Hitler dans son discours au Reichsparteitag de 1935, le jeune Allemand s'élèvera progressivement d'école en école. On le prendra en main tout enfant pour ne plus le lâcher jusqu'à l'âge de la retraite. Personne ne pourra dire qu'il y a eu une période de sa vie où il a été laissé à lui-même ${ }^{17}$. " (TOURNIER, 1970, p. 326)

Le 26 septembre, la proclamation par Hitler de la levée en masse (Volkssturm) mobilisant les femmes, les enfants et les vieillards pour tenter de conjurer la défaite marqua une nouvelle étape de son ascension. (TOURNIER, 1970, p. 425)

Os excertos acima nos mostram que a existência do chanceler nazista é indireta, permeada por uma camada discursiva interna ao romance, ela é sempre transmitida em segunda mão, mas nunca alcançada, nunca visível ou palpável, nunca aprofundada. Tendo em vista que ele é destituído de aparência e de ação, destituído de autonomia em relação à própria obra, entendemos afinal como e porque a leitura de muitos críticos propõe um atalho e logo decifra o ogro Hitler numa metonímia do nazismo. Posto que a premissa da narrativa é que Hitler é apenas um humano, ele deixa de sê-lo - é o contrário perfeito (ou a inversão maligna) de Abel, cuja monstruosidade o aproxima cada vez mais da humanidade.

\footnotetext{
${ }^{17}$ Essa citação Tournier indica, em nota, que é verdadeira. Ela consta em Generation im Gleichschritt (Stalling éd.) de W. Klose.
} 
O ogro nazista alterna facilmente de lugar com o nazismo ogro, os dois são na prática a mesma figura, uma desdobrando-se na outra, uma determinando a outra.

As passagens referentes à ideologia do Terceiro Reich procuram intensamente relacionar o alistamento de jovens à sua morte, à sua destruição. Nesse sentido, é exemplar a cena em que Abel vê as aves migratórias (no dia em que Hitler anuncia o avanço das tropas) e silenciosamente lamenta pelos meninos que vão morrer. Tratase de uma passagem muito significativa, pois conjuga o substrato violento e desesperador da guerra com a manifestação triste e melancólica dos vivos em relação à morte. Recuperando o hibridismo mítico das crianças-pássaros, o narrador encontra a justa expressão da dor de Tiffauges:

Le 3 octobre Hitler annonça au monde dans un discours au Palais des Sports de Berlin le déclenchement de l'opération Typhon qui devait faire tomber Moscou et anéantir définitivement l'Armée rouge. Et de nouveau, le pays fut sillonné par un afflux d'hommes et de matériel, des hommes de plus en plus jeunes, un matériel de plus en plus perfectionné, jetés pêle-mêle dans l'immense fournaise de la bataille. Aussi quand les premiers oiseaux migrateurs commencèrent à passer très haut contre les nuages gris, en gémissant, Tiffauges pensait, la gorge serrée, à toute cette jeunesse fauchée dans sa fleur, et il lui semblait que c'était les âmes des tués qui fuyaient là-haut, esseulées, effrayées par le mystère de l'au-delà, pleurant cette terre familière et maternelle qu'ils avaient eu si peu le temps d'aimer. (TOURNIER, 1970, p. 258)

Parece claro que, no romance, a grande questão do nazismo, muito além de promover o racismo e o massacre, é de mobilizar as crianças de modo que seu sacrifício seja voluntário, desejado, que elas se esforcem por isso. Se Hitler cuidou de identificar e perseguir aqueles que considerava inimigos, um a um, se ele isolou simbolicamente cada etnia e comunidade que odiava, com a Hitlerjugend o processo funcionou de modo contrário. Ele recebeu e acolheu cada uma das crianças nas napolas e fez delas o material humano a ser gasto em suas conquistas. Simbolicamente, os jovens recrutados ofereciam suas vidas pelo Führer e faziam 
juramentos de sacrifício pela pátria, pela honra, pelo sangue ariano. Assim, Tournier engendra na obra uma crítica que parte de dentro de uma dessas instituições, ele insere seu personagem numa das napolas para fazê-lo testemunhar o processo de militarização, ou seja, de morte simbólica dos meninos. Bouloumié (1988) considera esse um dos pontos fortes da originalidade de Michel Tournier:

Le roman décrit la vie d'une napola, sorte de microcosme de l'Allemagne nazie : les spectacles nocturnes aux effets pathétiques, aux mises en scène théâtrales $y$ constituent une sublimation esthétique de la mort et un appel au sacrifice : torchères, oriflammes, stridence de trompettes, grondement des tambours, voix véhémentes et accusatrices saluent les ombres des morts pour galvaniser les Jungmannen par l'exemple du sacrifice (TOURNIER, 1970, p.106).

Dentro do sistema cognitivo da narrativa, as napolas e todo o sistema de alistamento e convencimento de jovens constitui a expressão máxima dos rituais malignos e a radicalização do ogro devorador. Assim, um ogro que exige das crianças dedicação e sacrifício, que investe na sua formação e as convence de buscar na guerra e na ideologia da depuração da raça a verdade de suas almas e corpos, este certamente é um ogro predador, sistemático e insaciável. A materialidade de sua refeição está justamente nas vidas que interrompe, ou porque elas são destruídas nas trincheiras, ou porque são destruídas simbolicamente; e sobre esse massacre covarde, essa armadilha que o ogro nazista prepara para os pequenos de seu país, Abel insiste muito ao longo de todo romance, em especial em seu período na napola.

Toda a trajetória da personagem Stefan Raufeisen, nesse sentido, ilustra de maneira impressionante e explícita o grau de entrega e envolvimento dos integrantes da juventude nazista. Oriundo de uma família pobre e camponesa, o jovem Raufeisen aderiu ao partido nacional socialista em meados da década de trinta por acreditar 
que "tout autre recours que celui de l'épée était laîche et traître", e assim chega a chefe supremo da napola onde Abel trabalhava. Descrito como um "soudard inculte et aviné" (TOURNIER, 1970, p. 432) Stefan é um homem cruel, sádico, agressivo. Na napola, enquanto ele marcha sobre os meninos deitados, esmagando um dorso, uma nuca, uma cabeça, ele simbolicamente demonstra, nas palavras de Bouloumié, que o nazismo esmaga a juventude e a vida que alega exaltar (1988, p.111).

É sob o comando de Raufeisen que os meninos da napola serão massacrados pela artilharia soviética, frustradas as tentativas de rendição das portas do castelo. Prestes a fugir com Éphraïm, Tiffauges nota, de relance, "des corps de trois Jungmannen gisant pêle-mêle sur l'affut d'un F.M pointé vers le rectangle noir de la fenêtre" (TOURNIER, 1970, p. 489). Essa é a última imagem da guerra antes do desfecho mítico da narrativa; é significativa, evidente, porque se concentra nos meninos usados pelos militares e mortos em nome deles. Nota-se, nessas passagens de hiper-realismo em que o narrador nos descreve em detalhes as explosões, tiros, os ferimentos nos corpos dos soldados (como o rosto mutilado de Raufeisen) que nem toda a carga dramática e as alusões míticas dão conta desse culto ao mal, a guerra que põe em jogo um exército de jovens. 


\section{VERTIGEM NA VOZ E NO TEMPO DA NARRATIVA}

A memória é uma província da imaginação.

Paul Ricœur

\subsection{Tradição e subversão, forma e conteúdo}

Quando afirma, em sua autobiografia, que o propósito de sua obra "n'est pas d'innover dans la forme, mais de faire passer au contraire dans une forme aussi traditionnelle, préservée et rassurante que possible une matière ne possédant aucune de ces qualités" Michel Tournier (1977) nos indica que é possível haver uma cisão, e mesmo um descompasso, entre forma e conteúdo de uma obra. A inserção de seus romances numa tradição literária romanesca ficaria por conta de uma elaboração narrativa convencional e bem sedimentada no cenário da literatura francófona, enquanto a mensagem, as apropriações míticas e a trama trabalhariam no sentido de construir uma obra desafiadora e mesmo intransigente.

Mariska Koopman-Thurlings ${ }^{18}$ indaga se, justamente, não há um paradoxo nessa proposição, e se a unidade da obra necessariamente põe em xeque essa aparente ruptura entre forma e conteúdo. Considerando que tudo relativo ao texto, afinal, está dentro dos domínios do narrador e da estrutura discursiva em que ele se determina, ou a forma do romance tournieriano não é tão rassurante quanto o autor afirma, ou seu conteúdo não é tão subversivo quanto ele gostaria.

\footnotetext{
${ }^{18}$ In : Images et signes de Michel Tournier. « De la forme et du fond : le dédoublement discursif »p. 279
} 


\subsubsection{O modelo narrativo}

Em grande parte, o esforço da análise até aqui foi no sentido de decantar os mecanismos de atuação e desenvolvimento das personagens e dos conceitos, inserindo-os na compreensão das dimensões mítica e histórica do romance; se existe pois algum traço de tradicionalismo ou conservação na forma, ele se manifesta necessariamente através da voz narrativa que conduz os elementos ficcionais e historiográficos e costura, afinal, as dimensões ontológicas da obra. É intenção desta parte final do trabalho testar a declaração do escritor sobre seu próprio texto e observar se, de fato, as estratégias narrativas empregadas trabalham a serviço da conformidade e da tranquilidade da experiência de leitura.

Procuramos, sobretudo no primeiro capítulo, ressaltar a importância da estrutura narrativa em primeira pessoa ${ }^{19}$ dos "Écrits Sinistres" no estabelecimento de dois aspectos da personalidade do protagonista: um deles que se autoproclama monstruoso e submete o tempo e os acontecimentos a sua história pessoal; outro que se percebe inserido num contexto social específico e conflituoso e que lança mão de diferentes tipos de manifestações para expressar sua reação. Assinalamos então que, dadas as peculiaridades da voz narrativa de Tiffauges, o fato de os "Écrits Sinistres" serem a parte introdutória do romance facilita a sedimentação de um plano mágico e transcendente ao mesmo tempo em que revela uma consciência crítica face aos eventos políticos na Europa do fim da década de 30 .

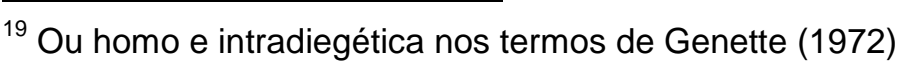


A comparação entre a personagem Tiffauges e o narrador Tiffauges evidencia que entre eles há algum distanciamento, ou pelo menos uma descontinuidade. Abel cuidou de montar sobre si mesmo uma imagem fantástica e impressionante, referindo-se a peculiaridades de seu corpo, reflexo de uma personalidade monstruosa, que ele afirma ser facilmente percebida pelas pessoas de modo geral. No entanto, a animalidade, que ele apenas sugere, e o apelo que as forças primitivas têm sobre si não encontram na escrita uma projeção compatível. Antes, ele comprova ser versado em filosofia e teologia, domina um vocabulário requintado e formas complexas da língua francesa e, sobretudo, possui uma verve analítica, reflexiva, interpretativa que apenas o discurso mais digressivo consegue comportar. Assim, seus escritos sinistros não parecem ser exclusivamente um exercício de rememoração, mas também a vazão de uma intelectualidade fértil, inquieta e laboriosa. A expressividade do narrador Tiffauges é aguda, ela dá conta, como dissemos, de sedimentar razoavelmente bem a esfera mítica na qual ele alega inserir-se manipulando com maestria a temporalidade de suas lembranças e convicções. De tal modo a escrita de Abel é consciente que ela não contém nenhuma pista de hesitação ou rasura, ela é firme em sua constituição formal, ou seja, sintática e retoricamente. Então, a monstruosidade de Abel, sua animalidade e seu primitivismo paradoxalmente dependem de seu requinte intelectual e linguístico para existirem, quanto mais fluente for a capacidade narrativa de Tiffauges, mais sólida será a caracterização de sua personalidade feérica enquanto personagem. Abordamos também, em "Os limites da expressão", a limitação que a linguagem sofre quando tenta registrar uma experiência violenta e traumática. Assim, a ligação de Abel com o curso dos acontecimentos, seu pacto com a essência humana o mantém em contato com o sublime e, ao mesmo tempo, com o horror. Diante da 
contingência, no extremo oposto da instância metafísica onde o narrador procura justificar e alocar sua própria existência, o que ele faz é elaborar da melhor maneira que pode imagens que traduzam, de algum modo, a angústia que sente, e então entendemos as imagens delirantes e os pesadelos que descreve.

A partir da segunda parte do romance, e até seu desfecho, os escritos sinistros são intercalados com passagens de uma narrativa feita por outro narrador, uma voz externa e distinta, o que determina muito claramente a atuação de uma narração intra e homodiegética e de outra, extra e heterodiegética.

Esse narrador externo tende a levar a ação com mais dinamismo do que Tiffauges, que usa o diário para interpretar e refletir sobre os acontecimentos. Além disso, Tiffauges, em sua narrativa, usa a si mesmo como um personagem para tornar coerente e aceitável sua história, ele confecciona seu discurso com tamanho cuidado e minúcia que a alternância com o narrador externo, em muitos aspectos configura mais uma continuidade do que o contrário. Ambos os narradores possuem o mesmo vocabulário refinado, as mesmas construções formais e eloquentes. Sobretudo, o livre acesso à subjetividade de Tiffauges fazem desse narrador externo, pelo menos a princípio, um desdobramento do narrador Tiffauges enquanto confere alguma objetividade a tudo aquilo que, até agora, poderia ser fruto de uma mente delirante. Ou seja, o discurso indireto livre coloca o narrador tipo "terceira pessoa" à disposição da mentalidade tiffaugeana, de tal modo que os elementos míticos e sobrenaturais são processados e camuflados na suposta objetividade que costuma ser atribuída de antemão ao narrador extradiegético.

16 janvier 1938. [...] Sa face cachée, que je fus le seul à soupçonner, c'était les signes, le déchiffrement des signes. C'était là la grande affaire de sa vie, avec le 
despotisme absolu qu'il faisait peser sur tout Saint-Christophe. De quels signes s'agissait-il? Que révélait leur déchiffrement? Si je pouvais répondre à cette question, toute ma vie serait changée, et non seulement ma vie mais - j'ose l'écrire assuré que personne ne lira jamais ces lignes - le cours même de l'histoire. (TOURNIER, 1970, p.36)

Personne n'avait autant que lui la conscience de son destin, un destin rectiligne, imperturbable, inflexible qui ordonnait à ses seules fins les événements mondiaux les plus grandioses. Mais cette conscience impliquait également une lucidité sans indulgence à l'égard de l'accidentel, de l'anecdotique, de toutes ces menues babioles auxquelles le commun des mortels s'attache et laisse des lambeaux de son cœur quand il faut partir. (TOURNIER, 1970, p. 245)

A voz narrativa externa se presta então ao suporte da grande personalidade que é Tiffauges, ela não o confronta e tampouco se sobrepõe a ele, antes, ela simplesmente viabiliza que sua perspectiva, tão característica, conduza a interpretação e a configuração da narrativa.

É certamente um mérito da obra que dois narradores tão diferentes quanto ao distanciamento e pertencimento à história em si configurem algum tipo de continuidade. Com efeito, é isso que pretendemos demonstrar até agora: há uma proximidade e uma complementação na atuação das vozes narrativas, ainda que elas sejam formalmente distintas uma da outra.

Pautando-se nas considerações de Genette (1972), é possível notar, também, pontos em que as duas vozes - a de Abel e a do narrador externo - se dissociam. Isto é, a homogeneidade com que ambas trabalham em função da esfera mítica não impede que se crie algum tipo de instabilidade ou heterogeneidade na narrativa de modo geral, a começar pelo fato de que Le Roi des Aulnes compreende uma história contada a dois, numa alternância de funções e atuações.

O manuseio dos tempos verbais constitui o primeiro dos elementos que apontam a dissociação das vozes, e implica numa camada de temporalidade externa à da 
trama central na qual a voz narrativa extra e heterodiegética se situa. Narrando a história no passé simple, esse narrador externo não indica apenas que está num momento ulterior em relação à narrativa do diário, mas também que toda a trajetória que nele se procura registrar encontra-se definitivamente encerrada. Assim, enquanto a trajetória de Tiffauges, incluindo seu diário, é datada e facilmente situada numa linha histórica e cronológica, a atuação do narrador heterodiegético é atemporal, o que o aproxima muito mais das instâncias míticas do romance. $\mathrm{Na}$ alternância entre os "Écrits Sinistres" e o turno narrativo em terceira pessoa os parâmetros temporais ficam suspensos, pois embora o leitor saiba que a história começa em 1938, não sabe ao certo quando ela termina e tampouco quando ela começa a ser contada. Mesmo o diário de Abel, que constituiria um canal direto de comunicação entre o protagonista e o leitor, depende dessa voz externa para Ihe dar espaço e sustentação pois implicitamente sabemos que o narrador teve acesso, antes de nós, aos escritos de Tiffauges.

Não é possível, nem ao leitor mais atento, desvendar completamente a relação entre o narrador heterodiegético e o narrador homodiegético. Mariska Koopman-Thurlings defende (1990) que toda atuação do narrador heterodiegético é um desdobramento de Tiffauges - o "verdadeiro" narrador que domina toda a diegése - e que isso constitui um artifício do autor para garantir a ironia e uma certa dinâmica na história. Com efeito, a livre transitividade entre as vozes narrativas permite tal leitura; o narrador heterodiegético poderia de fato constituir uma espécie de desdobramento atemporal de Tiffauges, como um recurso que, além de conferir ironia ao texto, viabilizasse a continuidade da narrativa independente ao diário - sobretudo às questões práticas que envolvem sua escrita para a personagem de Abel. Assim, por se identificar com Abel, o narrador estenderia sua voz quando ele não pudesse ou 
não desejasse escrever, permitindo que sua atuação corresse livremente sem deixar de ser registrada.

Tendemos, entretanto, a considerar o narrador heterodiegético como um elemento independente, ainda que semelhante e por vezes complementar ao narrador homodiegético. Em primeiro lugar, por conta da atemporalidade, que já mencionamos anteriormente. Em segundo lugar, porque embora a relação entre Abel Tiffauges e o narrador heterodiegético seja estreita, ela não é a única relação que se estabelece no romance. $O$ discurso extra e heterodiegético abre lacunas onde as vozes de outras personagens poderão se instalar e, assim, construir a polifonia que caracteriza definitivamente a estrutura narrativa de Le Roi des Aulnes.

O jogo entre o narrador homodiegético e o heterodiegético predomina em toda a obra e compreendem o núcleo mínimo do modelo de narração elaborado pelo autor. Alguns personagens, porém, abrem um espaço na continuidade discursiva em que os dois se mantém e inserem, no meio da narrativa, uma voz completamente diferente. É o caso, por exemplo, da longa fala de Stefan Raufeisen (p. 357), um dos líderes da juventude hitlerista, inserida no meio da narrativa. Ele conta toda a história de dificuldades financeiras que o fez aderir ao partido nacional socialista e termina seu relato apaixonado descrevendo o encontro da juventude hitlerista e seu voto de servidão ao Führer:

Mais rien jamais ne surpassa la journée du $1^{\mathrm{er}}$ octobre 1932. Le parti avait loué trente-huit tentes géantes pouvant habiter au total mille participants. Ils furent plus de cent mille filles et garçons qui affluèrent de toutes les provinces du Reich. Grandiose mêlée d'amitié ! Le ravitaillement était nul ! la fatigue surhumaine. Nous vivions tous sur nos nerfs, ivres de chants, de cris, de marches et de contremarches. Oui, la marche ! Elle était devenue notre mythe, notre opium ! (...) Nous avions dépassé la tribune dans un tonnerre acidulé de fifres, quand un aide de camp du Führer courut nous rejoindre :

_ Le Führer m'envoie demander qui vous êtes ! 
_ Dis-lui que nous sommes pour le servir et pour mourir les Hitler-Jungen de Kiel! (TOURNIER, 1970, p. 359)

ou da cena em que o Kommandeur da napola instrui os meninos a respeito da cerimônia que marca sua entrada oficial na juventude hitlerista. Sua fala descreve o protótipo do militar heróico, impassível e pragmático, estendendo sobre essa figura a desumanização necessária para fazer dele um homem eficiente e forte. Nesse sentido, seu discurso contrasta formalmente de todo o estilo digressivo, instável e subjetivo de Abel.

- Jungmannen, dit-il, on va procéder cette nuit à une cérémonie qui est le point culminant de votre jeune carrière. (...) Haïo, Haro et Lothar vous porterez désormais au côté gauche le glaive dont la double invocation Sang et Honneur dominera votre vie et votre mort. (...)

Les Porte-Glaive n'étaient qu'une poignée, quelques centaines, ni plus ni moins que vous, Jungmannen, réunis dans cette salle. Mais c'était des géants! Ils ne possédaient rien, ni richesse, ni femme, ni même une volonté propre ayant prononcé les vœux de pauvreté, de chasteté et d'obéissance. (TOURNIER, 1970, p. 415-6)

Ainda que Tiffauges e o narrador constituam uma unidade discursiva relativa entre si, a disposição das personagens e da própria estrutura narrativa não Ihes permite sustentar a homogeneidade do discurso. É próprio de Abel o crivo sob o qual os militares passam para serem caracterizados como verdadeiros monstros na obra, mesmo quando o turno narrativo pertence ao narrador externo; essa monstruosidade não é exatamente uma consequência lógica do pensamento tiffaugeano, antes, ela foi conquistada às custas de apropriação de sinais, de interpretação, de um pensamento tortuoso e indireto que formulou, afinal, o caráter tenebroso e sobrenatural do nazista.

Deste modo, a inserção de uma longa fala do Kommandeur, mostrando um pragmatismo e uma racionalidade a toda prova, embora não represente uma 
contradição com a imagem monstruosa do militar nazista, constitui uma quebra formal, um conflito de modalidades discursivas. Enquanto Abel transita pelo onírico, por estados de embriaguez religiosa, ou depressão e melancolia, o comandante Alei sustenta uma visão objetiva do mundo, da guerra, da carreira militar dos meninos. $\mathrm{O}$ céu não se abre para ele, e tampouco o inferno - e, nessa discrepância, a obra sugere o dilema histórico em que está inserida, ou seja, a multirreferenciação discursiva e ideológica interna à narrativa mimetiza o quadro político e moral problemático do qual a guerra e a Shoah resultam. Em última instância, se à lucidez e pragmatismo do comandante corresponde um plano próximo da realidade mais trivial, aquela na qual o leitor reconhece os próprios paradigmas, é possível que em contrapartida o discurso de Abel Tiffauges perca sua força crítica, porque reconhecidamente onírico, fantástico, extravagante e exagerado. O desafio que se apresenta ao leitor é justamente perceber, nas camadas de intertextualidade e fabulação, uma relação (e uma reação) direta com a realidade mais violenta - da qual o discurso militar é caudatário.

A polifonia faz com que as vozes, independente de sua predominância ao longo do romance, concorram igualmente e determinem os parâmetros conceituais do leitor e, desse modo, haverá tantos recortes quantas forem as vozes narrativas. Há uma questão de ordem cognitiva subjacente a essa estrutura narrativa: a loucura associada à perda da alma. Quem está louco?, o leitor deve se perguntar, menos preocupado em atribuir razão a um dos lados do que identificar qual discurso, afinal, aponta o momento preciso em que perdemos tudo. Nota-se a projeção do dilema da loucura em tempos de guerra nesta passagem em que Abel fala sobre Victor, um homem enlouquecido que ele conheceu enquanto era prisioneiro dos alemães, e que agora reaparecia como presidente da câmara em uma cidade vizinha. Por uma 
série de fatores, e por uma questão de sorte, Victor conseguira a estima de um poderoso comandante nazista e tornara-se o responsável pela distribuição de senhas no sistema de racionamento de alimentos. Consternado, Tiffauges afirma que

Et il éclatait de son rire de dément en évoquant toutes ses merveilles ! À mesure qu'il parlait, j'étais envahi par un double malaise. Cette réussite insolente, c'est celle précisément que j'ambitionne depuis mon arrivée en Allemagne, et son spectacle m'emplissait d'un sentiment d'amère jalousie. Mais surtout il m'était pénible de constater que c'était à sa folie même que Victor la devait, et je me rappelais une fois de plus le diagnostic que Socrate avait porté sur Victor et qui m'avait si vivement impressionné : un déséquilibré auquel un pays bouleversé par la guerre et la défaite offre le seul terrain qui convienne à son plein épanouissement. $\mathrm{Ne}$ suis-je pas finalement un autre Victor, et mon seul espoir n'est-il pas que les coups du destin placent Kaltenborn au niveau et à la merci de la folie qui m'est propre ? (TOURNIER, 1970, p. 343, grifos nossos)

Se Abel Tiffauges está louco, então toda sua trajetória é a expressão da individualidade que nega a realidade e formula uma alternativa fantástica para o fim com o qual não consegue lidar. A loucura do nazista, por sua vez, passa ao largo do questionamento moral que indaga se ele agiu de maneira correta ou não - pois esse questionamento não se apresenta sequer - para estabelecer, de maneira pessimista, que o curso dos acontecimentos que provocaram a Shoah faz parte não apenas da realidade, mas de um ato lúcido e próprio dos homens, e, se é assim, a alma humana já está de fato comprometida.

O ogro como metáfora

Se por um lado o modelo diegético incorpora diferentes vozes e projeta na polifonia a instabilidade dos parâmetros temporais, morais e discursivos, por outro ele usa a 
grande semelhança entre a atuação dos narradores - o hétero e o homodiegético para forjar uma aparente estabilidade. Dito de outro modo, observamos que alternância entre Abel e o narrador heterodiegético resulta na alternância de perspectivas e dificuldade de referenciação temporal, mas é preciso reconhecer também que a facilidade com que um discurso desliza para o outro, na maior parte do tempo, ironicamente acaba por nos dar uma impressão de que sua trajetória é linear. Assim, a estratégia narrativa do romance provoca uma sensação de conforto e continuidade precisamente quando ela abole qualquer possibilidade de referenciação segura da parte do leitor. Em não sendo precisa, objetiva e transparente - mas exatamente o contrário, a narrativa forja uma impressão de harmonia emanante da voz narrativa.

É desta maneira que nós mesmos somos envolvidos pelo texto e pelos paradigmas internos à obra, simbolicamente devorados enquanto aprendemos a identificar e atribuir sentido aos sinais que a narrativa vai oferecendo. É uma espécie de armadilha discursiva, um despiste que o narrador oferece enquanto elabora um modelo narrativo complexo, multirreferenciado, incerto.

É possível fazer ainda outra observação quanto à estratégia narrativa de Le Roi des Aulnes: os narradores não apenas intercalam suas falas como tendem a dominar a linha de raciocínio que conduz a trama. Eis uma das grandes dificuldades do crítico do texto tournieriano, seu narrador não é generoso o bastante para deixar facilmente que o leitor crie o sentido da obra, pelo contrário, ele intervém o máximo que pode a pretexto de esclarecer a própria diegése. No romance em questão, o narrador duplo reduz o espaço de reflexão e atuação do leitor, de modo a deixá-lo próximo da passividade diante de sua narrativa e da interpretação que ele mesmo faz sobre ela. 
Em relação a isso, Koopman-Thurlings (1990) afirma que esse tipo de intervenção e imposição narrativa só pode provocar uma reação no leitor: o desconforto, o ímpeto de ir contra um narrador que o impede de tirar suas próprias conclusões e fazer suas combinações (p. 287). A menos que o leitor deliberadamente se prostre diante do texto e assuma uma postura leniente em relação ao narrador, ele perceberá a tentativa de supressão de seu posto inalienável como produtor de sentido e precisará constantemente questionar o narrador, incomodar-se com ele e explorá-lo o máximo possível.

Estamos próximos, portanto, de uma leitura que contradiz a afirmação inicial de Michel Tournier sobre a propriedade tranquilizadora da forma de seus romances: uma estrutura narrativa de tal maneira complexa, multifacetada, polifônica e provocativa não apenas desvia dos padrões tradicionais das narrativas literárias como não permite que o leitor crie uma zona de conforto em sua experiência.

Recuperamos finalmente o título desta parte do trabalho: o ogro como metáfora do modelo narrativo. Retomando a definição que expusemos inicialmente, o texto "ogro" seria aquele que envolve e mobiliza o leitor, que o devora, que procura fazer a travessia do sentido por ele, e contra o qual é preciso se debater para reivindicar os hábitos de hermeneuta. Disso decorre que a leitura do romance provoca estranhamento, não apenas por conta de seu conteúdo, mas porque sua maneira de dizer o que diz é em si desconcertante. 


\subsection{A estrutura temporal}

Ao longo de toda a análise procuramos pontuar a ambiguidade das personagens e do próprio enredo, atrelando a isso uma intenção estética e crítica da parte do autor; a esta ambiguidade dos elementos da trama corresponde a instabilidade e o hibridismo dos elementos formais. Assim como o modelo narrativo do romance possui aspectos que o afastam das narrativas tradicionais e instauram, formalmente, o teor problemático que o conteúdo busca exprimir, também a o modelo temporal da obra contribui para o estranhamento e flexibilização de parâmetros do leitor, pois conjuga características do tempo mítico circular e do tempo histórico linear, configurando, assim, uma estrutura temporal peculiar e complexa.

\subsubsection{Tempo mítico e tempo histórico}

Embora a figura do ogro desempenhe papel imprescindível na instância transcendental da obra, deve-se reconhecer que o aparato mítico é essencialmente religioso, sobretudo cristão. A presença de São Cristóvão, a busca pela restituição do mito adâmico e a moralidade baseada nos conceitos de bem e mal (relacionados em alguma medida a Deus e Diabo) determinam inequivocamente um intertexto entre as escrituras bíblicas e o romance, a ponto de Bouloumié, como vimos, afirmar que Le Roi des Aulnes é "uma interpretação religiosa do nazismo" (1988, p. 112). Com efeito, todo o suporte mítico da obra advém da tradição judaico-cristã e é complementado com elementos oriundos de outras culturas e tradições, como a própria figura do ogro, do Rei dos Álamos, a noção de destino, as figurações 
fantásticas dos animais e das plantas, ou seja, tudo aquilo que foge de uma representação "realística" acaba participando do domínio mitológico do romance.

Estruturalmente, esse domínio depende de estratégias narrativas que estabeleçam as bases sobre as quais a trama poderá se desenvolver. É preciso, por exemplo, que uma espacialidade ${ }^{20}$ e temporalidade sacralizadas caracterizem inequivocamente a transcendência, ou pelo menos a suspensão do funcionamento ordinário da vida.

Circularidade do tempo mítico

Quando descreve o tempo sagrado, Mircea Eliade (1992) pauta-se na subjetividade do homem religioso, para quem a experiência litúrgica é capaz justamente de promover a ruptura da vida ordinária e o restabelecimento absoluto da divindade. Diferente do tempo profano, ou secular, o tempo sagrado é por sua própria natureza reversível, posto que é um "tempo mítico primordial tornado presente" (1992, p. 63). Eliade associa a reversibilidade do tempo mítico às cerimônias e festas sacras, que representam uma reatualização de um evento que teve lugar num passado mítico último. A compreensão da temporalidade sagrada, evidentemente, obriga o homem a dispor de parâmetros cognitivos específicos, pois esse tempo "não 'flui', não constitui uma duração irreversível. É um tempo ontológico por excelência, mantémse igual a si mesmo, não muda nem esgota" (1992, p. 64). A circularidade, pois, define o ritmo e o funcionamento dessa instância temporal imutável mas reversível, inesgotável mas encerrado: o tempo sagrado não é o tempo no qual as coisas se desenvolvem, perecem e morrem, antes, ele constitui o Tempo, um presente

${ }^{20}$ Ver "Os espaços mágicos" 
eternamente recuperável que em nenhuma hipótese se consegue superar ou ultrapassar. O tempo sagrado compactua com o mistério e com a arbitrariedade do ritual, mas oferece, em contrapartida, uma espécie de chave de compreensão da existência - estamos, como se pode perceber, no centro da substância religiosa.

O tempo mítico é o tempo da instauração do mundo, da existência, da natureza, é o tempo da criação e, em decorrência disso, a reiteração dos gestos e das palavras que instauram o tempo mítico nas brechas do tempo profano aproxima periodicamente o homem de seus deuses, "reatualizando o Tempo primordial no qual se realizaram obras divinas" (ELIADE, 1992, p. 79). Com efeito, a força motriz do ritual religioso está no desejo que o homem sente em reintegrar a situação primordial: aquela em que os deuses e os antepassados míticos estavam efetivamente presentes, quer dizer, "estavam em via de criar o mundo, ou de organizá-lo ou de revelar aos homens os fundamentos da civilização. Essa 'situação primordial' não é de ordem histórica, não é cronologicamente calculável, trata-se de uma anterioridade mítica, do Tempo da 'origem', do que se passou 'no começo', in principio." (ELIADE, 1992, p. 81-82)

A análise de Eliade a respeito da percepção do tempo do homem religioso tem uma intenção antropológica que, confrontada com o material que o romance Le Roi des Aulnes oferece, encontra pontos de contato tanto quanto incompatibilidades. $\mathrm{O}$ funcionamento cíclico do tempo se projeta razoavelmente bem na obra, mas não às custas de rituais religiosos propriamente, mas de um processo de reiteração de sinais, entre os quais a foria se destaca, que visam restituir o Adão original. A respeito desse procedimento de restabelecimento do mito adâmico, dedicamos boa parte do capítulo "Configurações do Mal", voltando-nos, contudo, para a conceituação religiosa do romance. Se voltamos a esta questão, agora, é porque 
falta analisar o efeito que essa reiteração tem sobre a configuração temporal na narrativa, uma vez que Adão primordial não sela apenas um legado à humanidade enquanto espécie, mas determina o ponto inicial do Tempo sagrado.

Ora, se o mito adâmico é recuperado a cada gesto de foria, e se a foria ela mesma se reapresenta nas figuras também míticas de São Cristóvão e do Rei dos Álamos, podemos concluir que este é o gesto que marca, ao longo de todo o romance, a reversibilidade e a circularidade do tempo. A foria confere universalidade ao mito de Adão hermafrodita, ela estabelece uma conexão invisível, mas ainda existente, entre elementos tão distintos quanto possíveis para mimetizar, dentro da narrativa, o eterno retorno que caracteriza o tempo sagrado do homem religioso - é preciso apenas que alguém esteja familiarizado com os sinais, como é o caso do protagonista e do leitor.

Ainda que não configure um ritual propriamente, o ato fórico eleva o gesto humano às raias da transcendência (e para isso basta lembrar-nos das descrições maravilhadas que Abel faz de suas experiências de carregar uma criança), ao mesmo tempo que viabiliza o desenvolvimento da monstruosidade de Abel. Assim, não apenas o mito adâmico funciona numa espécie de ciclo, mas também Abel, em certa medida, depende da reiteração dos sinais para tornar-se o ogro que ele acredita ser.

Há ainda um segundo tipo de realização do tempo mítico na obra, ele inclui o aspecto festivo e estético do Terceiro Reich, que já abordamos anteriormente. Michel Tournier, que presenciou os desfiles militares e as manifestações populares em prol do nacional socialismo, dedicou-se a projetar em seu romance um caráter quase hipnótico às festas do Reich nazista. 
Ce matin (...) grande parade militaire sur l'Adolf-Hitlerstrasse. Foule. La moitié de cette foule en uniforme - c'est-à-dire uniformisée, homogénéisée, confondue sous le même drap, le même cuir, le même acier (...) Cette foule-là est très avancée dans la métamorphose qui fait de plusieurs millions d'Allemands un seul grand être somnambule et irrésistible. (...)

Le phénomène n'est encore qu'à l'état naissant dans l'autre moitié de la foule, celle des civils dont l'écume irrégulière et multicolore s'accumule en désordre sur les trottoirs et sous les arbres. (...) Cette musique triste et obsédante, le piétinement sourd des légions en marche, les travées régulièrement soulevées par la même houle, les étendards à croix gammées qui se caressent soyeusement sous la brise - tout ce rituel d'envoûtement agit en profondeur sur leur système nerveux, et paralyse leur libre arbitre. Une douceur mortelle les prend aux tripes, mouille leur regard, les immobilise par une fascination exquise et vénéreuse qui s'appelle : le patriotisme. Ein Volk, ein Reich, ein Fürer. (TOURNIER, 1970, p. 338-9)

Vemos operar a transferência da apoteose transcendente da esfera religiosa para a política, isto é, enquanto a excepcionalidade de Tiffauges se desenvolve fortemente vinculada à uma tradição religiosa - ainda que distorcida - a configuração do nazismo absorve igualmente uma carga ritualística intensa sem deixar, contudo, de pertencer à esfera política e ideológica. O nazismo mobiliza toda a estrutura psíquica devota à religiosidade, sobretudo no caso da juventude hitlerista, alterando contudo os termos da equação:

Il m'a fallu du temps pour sautes en marche dans ce grand carrousel pavoisé, criard et bariolé qui entraîne une foule d'enfants et une poignée d'adultes. Maintenant que j'y suis, je comprends mieux à quels ressorts il obéit. Visiblement, la trajectoire du temps est ici - non pas rectiligne - mais circulaire. On vit non dans l'histoire, mais dans le calendrier. C'est donc le règne sans partage de l'éternel retour - en quoi l'image du carrousel est pleinement justifié. L'hitlérisme est réfractaire à toute idée de progrès de création, de découverte et d'invention d'un avenir vierge. Sa vertu n'est pas de rupture, mais de restauration : culte de la race, des ancêtres, du sang, des morts, de la terre...

Dans ce calendrier dont les saints et les fêtes révèlent d'un martyrologe particulier, le 24 janvier est pour l'éternité le jour de l'an de disgrâce 1931 où mourût le jeune Herbert Norkus, saint patron, en raison de son âge, de toutes les organisations de jeunes. (TOURNIER, 1970, p. 355) 
A descrição que Tiffauges faz do funcionamento do tempo na napola coincide quase perfeitamente com a descrição temporal que encontramos em Eliade (1992), ou seja, a concepção de tempo, dentro da instituição de formação dos Jungmannen obedece um sistema circular, fechado, contrário à transformação e evolução do pensamento e do comportamento. Diferente, no entanto, do homem religioso que procura restituir um tempo primordial passado num presente momentâneo, o nazismo busca à força estender o presente, cristalizá-lo e fixar os meninos nessa temporalidade que imediatamente ganha status de realidade, de cotidiano.

\section{Linearidade do tempo histórico}

A temporalidade da obra não se restringe à circularidade religiosa que marca - de maneiras distintas, como vimos - a formação dos meninos na napola e parte da trajetória de Abel; há uma narrativa histórica no romance, que por vezes fica velada em referências indiretas a personagens e eventos reais, mas que nunca perde de vista os principais acontecimentos relacionados à ascensão e queda do nazismo na Europa. Essa historicidade também mobiliza uma estrutura temporal que the é própria, operando basicamente em duas instâncias para viabilizar a linearidade que habitualmente se confere às narrativas históricas tradicionais: em primeiro lugar, graças aos "Écrits Sinistres", as ações são inteiramente pautadas numa sequência cronológica, ainda que relativamente ambígua - como veremos mais adiante. Em segundo lugar, por mais digressivas que sejam as passagens narradas por Abel, e por mais que sua trajetória funcione parcialmente dentro de uma circularidade, ela também avança, tem um começo, meio e fim, ou seja, ela segue uma ordem lógica, nítida e - devemos ressaltar - linear. 
Ironicamente, a linearidade da narrativa, seja pela cronologia estabelecida seja pela evolução das ações rumo a um desfecho que lhes encerre definitivamente, é muito mais perceptível ao leitor do que a própria circularidade mítica da obra, embora a influência da esfera sobrehumana seja muito mais marcada nas personagens e na trama. A temporalidade cronológica e histórica funciona como organizadora da trama, como um fio condutor garantindo alguma sequência, mesmo se as referências temporais do leitor sejam constantemente ludibriadas pelas estratégias narrativas.

\subsubsection{Tempo em espiral}

Temos, então, que a estrutura narrativa de Le Roi des Aulnes comporta dois tipos de referenciação temporal: uma circular e outra, linear. A pluralidade de referências serve a uma certa fragmentação da configuração temporal da obra como um todo, gerando especificidades: no caso dos "Écrits Sinistres", devemos considerar que eles são feitos pelo narrador-personagem, através de um processo de reconstituição temporal retroativo e não-linear (o exercício da memória e da digressão) atrelado a um registro datado e seqüencial (a escrita no gênero do diário), ou seja, sua linearidade cronológica comporta dois movimentos contrários, que, coexistindo, eliminam as possibilidades de segurança na referenciação temporal. Não significa que a cronologia do diário esteja comprometida, mas que ela não se refere apenas aos acontecimentos do presente, antes, ela se projeta num emaranhado de lembranças: 
18 février 1938. Chaque fois que dans une voiture qui m'est confiée, j'aperçois vissé au tableau de bord le médaillon de Saint Christophe, je songe au collège de Beauvais, et j'admire l'une de ses constances qui courent tout au long de mon existence... (TOURNIER, 1970, p.48)

25 février 1938. Un jour Nestor sortit de son pupitre une petite boîte carrée en carton, et il l'approcha de mon oreille... (TOURNIER, 1970, p.50)

Como dissemos, a linearidade temporal, característica de um romance cuja pretensão é a expressão realística do mundo, mantém-se como uma das diretrizes marcantes da narrativa na medida em que pauta a dimensão histórica da obra. A Segunda Guerra, enquanto acontecimento, segue uma ordem ininterrupta, ascendente e una. No entanto, Abel passa pelos círculos territoriais nazistas sem vivenciar, com isso, o horror. A não-fragmentação do indivíduo, neste aspecto, viabiliza a não-fragmentação temporal. Com efeito, a voz narrativa externa desloca o fato da guerra de uma experiência vivida no aqui e agora (como seria a recepção caso continuássemos a acompanhar o diário de Abel) para um resgate de uma narrativa passada. Ou seja: a mudança de perspectiva do narrador altera a abordagem das ações e os efeitos da temporalidade; é um discurso que implementa uma epistemologia própria e, por isso, pode mimetizar uma narrativa quase tão objetiva quanto o discurso historicizante pretende ser.

Avec la mauvaise saison, les effectifs du camp avaient sensiblement fondu, l'Arbeitseinsatz envoyant les hommes isolément ou par petits groupes, en commandos lointains qui ne conservaient qu'un lien administratif avec la direction.( TOURNIER, 1970, p. 232)

Tiffauges avait le sentiment très vif qu'un lien d'appartenance l'unissait à cette terre. Pour commencer - et pour longtemps peut-être- il en était prisonnier, et il se devait de la servir de tout son corps, de tout son cœur. (TOURNIER, 1970, p. 227)

Por outro lado, a não-fragmentação temporal relativa à narrativa da guerra se deve também à potência da dimensão mítica, concentrada sobretudo no personagem de 
Abel. Ora, num romance realístico, as situações pelas quais ele passa seriam origem de trauma e desespero, mutilação e aniquilação, nos níveis físicos, simbólicos, emocionais, morais. A guerra, porém, torna-se uma experiência que afirma e fortalece o personagem em todos esses níveis, e por uma única razão: desde sua infância, Abel detêm um conhecimento que ninguém mais detêm, ele sabe que é predestinado a uma coisa grandiosa. Sabe que por trás de cada acontecimento há algo sublime, e esta certeza faz com que ele resista ao sofrimento "ordinário" mais explícito. Não devemos esquecer, contudo, que sua predestinação Ihe fora anunciada na infância, mas ele a vê confirmada ao longo de sua trajetória em inúmeros sinais, que nada mais são do que reiterações constantes de símbolos e imagens, como a ação da foria.

A reiteração de elementos e a obstinação com que Abel busca realizar seu destino, que ele sabe estar relacionado a histórias já passadas e perpetuadas como São Cristóvão e o Rei dos Álamos, engendram uma dimensão mítica cuja temporalidade é, como dissemos, circular. Abel ressignifica o mundo em que vive, e encontra nele uma dinâmica cíclica que acaba sendo incorporada ao enredo e estrutura do romance, caracterizando, assim, a outra diretriz forte do texto. Como diz Benedito Nunes, "as diferenças entre narrativa histórica e narrativa ficcional sobressaem em contraste com o velho parentesco que as une ao mito" (1988, p. 10). Deste modo, a representação temporal linear historicizante dos fatos coexiste com uma temporalidade circular que abarca diferentes tradições míticas e que acompanha tão-somente a trajetória particular do personagem.

Assim, o texto existe numa espécie de entre-lugar das configurações temporais, dos modos de narratividade. Todavia, seria um erro supor que uma dimensão segue paralela à outra, pois se a não-fragmentação do tempo, característica de uma 
diretriz, só é possível por causa da não-fragmentação da personagem, e que Tiffauges só se mantém resistente à condição humana por estar profundamente envolvido com uma dinâmica mitológica do tempo e dos fatos, somos levados a entender que as dimensões - a histórica e a mítica - se influenciam e determinam mutuamente.

Nesse sentido, ao cabo de uma narrativa linear, cujo tom é francamente ascendente, a cena final é o apocalipse esperado de uma guerra, ou melhor, dessa guerra.

Tiffauges logea les bâtiments incendiés, il se glissa contre les grilles du chenil où les onze dobermans massacrés à la mitraillette composaient le dernier tableau de chasse de Kaltenborn [...] comme un naufragé en plein océan qui nage distinct sans espoir de salut, il accomplissait tous les gestes qui auraient pour le mener à sauveté sans croire un instant qui en rechaperait. II traverse Schlangenfliess éclairée a giorno par les maisons qui brûlaient comme des torches, en lançant haut dans le ciel des colonnes de fumée illuminées de flammèches.[...]

Et à mesure de ses pieds s'enfonçaient davantage dans la landèche gorgée d'eau, il sentait l'enfant - si mince, si diaphane pourtant - peser sur lui comme une masse de plomb. II devait maintenant faire un effort surhumain pour vaincre la résistance gluante qui lui broyait le ventre, la poitrine, mais il persévérait, sachant que tout était bien ainsi. Quand il leva pour la dernière fois la tête vers Ephraïm, il ne vit qu'une étoile d'or à six branches qui tournait lentement dans le ciel noir. (TOURNIER, 1970, p.496)

O espaço é aniquilado sob bombas, pois não há vitória possível para o nazismo, tudo desfaz em ruínas e pântano e a história da humanidade encontra na destruição seu ponto máximo. Por outro lado, a ação de Abel e a transformação de Éphraïm em estrela cumpre o passo ritual que deve ser dado, é a perpetuação de um gesto (da foria), é uma estória que repete as anteriores e realiza o ciclo que se havia anunciado desde há muito. Um desfecho, portanto, que sustenta as formulações de temporalidade propostas, sempre sob a chave do hibridismo. 
Da história ao mito: a paródia

Temos, enfim, que as estratégias narrativas que Michel Tournier emprega em seu romance escapam à qualquer tradicionalismo, e que ele tece, através das configurações de suas personagens, da voz narrativa e da estrutura temporal, uma rede complexa na qual mito e história se determinam mutuamente e por vezes se confundem. Em sua prática de reescritura, o autor assinala a necessidade, para 0 romance, de dar conta de sua inscrição num momento histórico e ao mesmo tempo de conter uma história, uma fabulação.

Margaret Sankey, em seu artigo ${ }^{21}$, serve-se do conceito de paródia de Linda Hutcheon $^{22}$ para demonstrar como Tournier intensifica as características da forma romanesca para redefinir o papel de contador de estória em seu aspecto duplo de agente histórico e de artista criador:

Selon Linda Hutcheon, la parodie est « une forme d'imitation [...] caractérisée par une inversion ironique, qui ne s'exerce pas toujours aux dépens du texte parodiée ${ }^{23}$. Elle peut être "une moquerie enjouée et géniale des formes codifiables $^{24}$ », une méthode pour inscrire la continuité tout en permettant la distance critique. La parodie fonctionne ainsi pour insérer le texte dans l'histoire, en même temps qu'elle met en question les façons traditionnelles d'écrire et de voir. (SANKEY, 1990, p. 326)

Para que o texto funcione parodicamente, no entanto, é preciso que o leitor possa atualizar as estratégias narrativas utilizadas para produzir a inversão irônica, ele

\footnotetext{
21 "L'exemple de le roi des aulnes" In: BOULOUMIÉ, A. (Dir.); GANDILLAC, M. (Dir.). Images et signes de Michel Tournier: Actes du colloque du Centre Culturel International de Cerisy-la-Salle. [Paris]: Gallimard, 1990, p. 325

${ }^{22}$ HUTCHEON, A theory of parody, Methuen, 1985 apud SANKEY, M. id, p.326

${ }^{23}$ Ibiden

24 Ibiden
} 
deve agir como uma espécie de "decodificador de uma intenção codificada"25, ou seja, essa função decodificadora converge tranquilamente com o que se disse neste trabalho a respeito da iniciação do leitor na hermenêutica dos sinais, acrescentando apenas a importância da reescritura ficcional nesse processo. Segundo Sankey, o texto de Le Roi des Aulnes contém uma revitalização de mitos que, "em sua dimensão paródica, oferecendo múltiplos níveis de interpretação, é igualmente uma máquina de compreender e comentar a relação entre os mitos e a história das ações humanas, mas também de desvelar a relação entre o autor criador de mitos e suas criações"26.

Reiteramos, portanto, que Tournier oferece um olhar sobre a Segunda Guerra a partir de um distanciamento crítico privilegiado, enriquecido por toda a discussão pública que se promoveu na França a respeito dos acontecimentos das décadas de 30 e 40, de modo que, em seu romance, o código referencial histórico da guerra esteja muito bem elaborado e desdobrado como intertexto num código literário e mítico. Não apenas elaborado e desdobrado; a historicidade da obra, como vimos, permanece quase sempre subjacente e dependente de uma capacidade de leitura mais aprofundada do leitor que identifique nos elementos ficcionais e míticos a constante referência aos dilemas históricos que envolveram o nazismo. Sob esse ponto de vista, a busca de Tiffauges por seu destino torna-se sobretudo a busca por um sentido no meio de uma época caótica e beligerante, e por uma identidade numa época de dissolução da vida e da individualidade. Procurando sua própria significação,

\footnotetext{
${ }^{25}$ Ibiden.

${ }^{26}$ Ibiden, p. 327
} 
Tiffauges est en même temps le foyer d'un réseau complexe de stratégies et de structures narratives qui donnent sa signification au texte. Le texte par son titre se donne explicitement comme la réécriture d'un récit antérieur : il incorpore le mythe et l'histoire, et affirme donc son appartenance à une tradition historique et littéraire. (SANKEY, 1990, p. 328)

A trajetória de Abel, é sempre importante lembrar, em primeira instância, é individual. A linha mestre da narrativa é estabelecida a partir do pacto que Abel faz com seu destino, ou, se preferirmos, do pacto que ele faz com os sinais. O mundo de Tiffauges é antes de mais nada um mundo a serviço dele, cuja materialidade depende sobretudo de sua conformidade com os critérios e os códigos que Abel estabeleceu. É muito adequada a relação que Serge Koster (2005, p. 133) faz entre a palavra phorie e a métaphore no romance, percebendo aquela como radical desta última. O mecanismo de leitura é precisamente este, é o transporte do sentido, é também sua inversão. Com isso, a busca de Abel por seu destino o conduz até onde centro da guerra e, em seguida, o coloca em paralelo com diversos homens poderosos do Terceiro Reich. Ou seja, o desenvolvimento da história individual acontece sobreposta à toda trama histórica do romance. Situar-se num entre-lugar narrativo e temporal implica, assim, estar fora da história e ao mesmo tempo pertencer a ela, e na oscilação pontuar como uma esfera pode determinar a outra, ou melhor, que o mito é um ingrediente necessário à história assim como ele mesmo possui um aspecto histórico.

Todo o sistema de interpenetração da dimensão mítica e histórica é viável, afinal, através do que Freud (1959) chamou de experiência do estranho. Na lógica interna da obra, ou seja, dentro do sistema discursivo que a narrativa paródica compõe, importa que Hitler seja um ogro, uma figura monstruosa que suspende a ordem das coisas, desestabilizando-as, não apenas no campo da política, mas de maneira ontológica. Por desdobramento, importa que Abel seja também um ogro, a alteridade 
encarnada, um duplo que encontra a redenção e a aniquilação, no final, e que tudo isso se passe em um espaço de encantamento e morte.

Cada narrativa organiza suas características de bem e mal para desenvolver sua idéia de organização social e, assim, a convergência da monstruosidade e do heroísmo de Abel choca pois sua alteridade é resultado de uma potencialização daquilo que é mais particularmente humano: as perversões. Abel incorpora uma ambigüidade que Girardet (1987, p. 79) outrora atribuiu ao próprio Hitler, que gozava "do duplo prestígio de uma legalidade restaurada e do mistério do aventureiro predestinado. Mas sobretudo, no plano mais decisivo do psiquismo coletivo, porque as duas imagens se juntam e tendem a confundir-se na medida mesma em que podem, uma e outra, legitimamente aparecer como uma resposta a um sentimento semelhante de vacuidade".

Assim, quanto mais monstruoso e distante Abel fica dos homens para concentrar-se no seu projeto e destino, mais parece aproximar-se da demanda psíquica dos homens em tempos instáveis. No bojo dessa mesma demanda, Hitler aparece na obra também como uma espécie de entidade monstruosa, aparentemente afastado do campo político e social, mas como um catalisador das pequenas perversões de seus comandados, que viabiliza e incentiva a ação de aniquilamento da humanidade.

Por lidar com instâncias históricas e míticas, a obra conta com um conhecimento de mundo prévio do leitor - mundo que, afinal, será desafiado porque será deslocado e recombinado. Tudo o que é familiar está distorcido, deformado e transgredido, parece ser uma paródia "mais ou menos séria", e sobretudo necessária à economia da obra. O processo de reconhecimento e estranhamento é permanente e múltiplo, pois provocado dentro do enredo, entre elementos internos - por exemplo, a cada 
elemento repetido mas modificado - bem como entre a obra e o leitor - como a figuração dos militares ou as críticas ao nazismo. 


\section{CONCLUSÃO}

A intenção primeira deste trabalho era analisar as relações entre mito e literatura, pressupondo que a recriação mítica era a chave para a leitura do romance Le Roi des Aulnes. Com efeito, esta pode ser uma das principais vias de abordagem da obra de Michel Tournier de modo geral, mas no caso específico desse romance, a recriação mítica se mostrou um conceito insuficiente para a análise e interpretação literária. Talvez porque o contexto subjacente à obra constitua um dos pontos mais violentos da história recente e as feridas aindas estejam abertas; fato é que limitar o romance a sua esfera mítico-religiosa empobrece a compreensão da obra.

A pesquisa revelou que entre mito e história há vários processos de travessia de sentido, que operam graças à fabulação e à criatividade do autor, de modo que os elementos históricos foram incorporados à obra de maneira distorcida, velada, por vezes mitologizada, assim como os elementos míticos e fantásticos conduzem uma crítica severa à ideologia e política nazistas.

Os aspectos míticos da obra trabalham em função sobretudo de criar as balizas morais dentro das quais as personagens atuam, além de abrir um espaço para que 0 leitor participe da construção do sentido da obra na medida em que ele é envolvido pelas regras do sistema mítico configurado. Eis, basicamente, a chave para a compreensão do processo de escrita do diário de Abel, da reiteração dos sinais ao longo da trama, do conceito de inversão e da configuração do mal na narrativa; são estes os principais agentes míticos de Le Roi des Aulnes, isto é, em torno deles está organizada toda a transcendência do romance, incluindo forças malignas sobrenaturais e a própria fragilidade da condição humana. 
Por sua vez, a historicidade da obra conta sobretudo com a instabilidade dos elementos formais, bem como dos paradoxos e vicissitudes engendrados pelos elementos míticos para indicar, muito mais do que o registro de uma época, a projeção literária de uma dilema histórico. Em outras palavras, este romance é profundamente crítico e historicizante justamente porque ele não conta com uma linguagem realista, descritiva e estável; é no reconhecimento da precariedade da expressão, no momento em que apenas uma linguagem multireferenciada, delirante e irreal consegue abordar um contexto histórico problemático que a possibilidade de lucidez e elaboração desponta no horizonte.

Isso justifica, em grande parte, a dificuldade que o leitor encontra para situar a configuração do mal na obra: porque nesse romance o mal parece estar por toda parte, e portanto em parte alguma. Ao longo de toda a obra, o mal é atribuído ao demônio, aos homens, à fraqueza humana, à falha primordial, ao livre arbítrio, ele parece ser absoluto e ao mesmo tempo sutil; o mal é objeto de reflexões no diário de Tiffauges, ao mesmo tempo em que permeia a constituição de várias personagens incluindo, aliás, o próprio Abel. Entendemos que essa volatilidade do conceito do mal é mérito da obra, que procura mimetizar um conflito moral e filosófico - que permanece insolúvel - em todas as suas camadas constitutivas: por que isso aconteceu? Onde, afinal, estão os limites?

É pertinente se perguntar, contudo, por que afinal o narrador escolhe uma perspectiva mais próxima do algoz, considerando o evento todo da Shoah; por que a maioria absoluta das páginas se ocupa da napola e dos bastidores da guerra que instaurou campos de extermínio em detrimento, ao menos aparentemente, do horror das vítimas do nazismo como os judeus? 
O problema se refere menos às questões literárias do que à escolha em nível autoral, isto é, num plano consciente e imediato do processo de escrita - mas é uma questão que se apresentou durante a investigação e que insistentemente parecia se relacionar com o resto da análise.

Abel Tiffauges, em toda sua trajetória, se posiciona criticamente ao Terceiro Reich e expressa seu repúdio ao alistamento de crianças e adolescentes na máquina bélica, sublinhando que este é a grande perversão do do Reich hitlerista. No romance, de modo geral, o foco da crítica à ideologia nazista está nessa juventude sacrificada, frustrando as expectativas de quem espera encontrar, como se costuma encontrar pelo menos na literatura que aborda a segunda guerra, uma crítica mais consistente aos campos de concentração.

Sem deixar de reconhecer o abuso sobre os corpos e as mentes dos jovens alemães, essa observação tão categórica pode parecer deslocada, considerando tudo o que se sabe sobre as câmaras de gás, os experimentos, o extermínio em massa. Não se trata de escalonar o horror e determinar quem afinal foi mais vitimado (talvez a maior dificuldade esteja nessa incapacidade de organizar o pensamento e prestar condolências a todos os que pereceram por causa do nacional socialismo) mas de não deixar de situar, da melhor forma possível, o horror da Shoah especificamente e, nisso, o romance parece não lograr.

Enfim, a formulação a que se chegou, ao cabo da pesquisa, é que Tournier estrutura todo o romance a partir da figura do ogro e do ato fórico - ele mesmo afirma, em Le vent paraclet, de maneira anedótica, que se lhe tivesse acontecido de carregar uma criança em seus braços ele jamais teria escrito Le Roi des Aulnes - ou, talvez, a partir da figura da criança que se salva e que, em contrapartida e metaforicamente, 
salva aquele que a carrega. A Shoah, como dissemos, figura na obra como elemento constitutivo porque determina o contexto histórico que pôs a perder definitivamente a plenitude humana. A ausência de totalidade, de espontaneidade, a fragmentação do mundo, todos os indícios da perda da alma que marcaram a modernidade exponenciam-se em tempos de guerra, em especial uma guerra que fez do extermínio um negócio. Sob esse ponto de vista, a euforia provocada pelo ato fórico, buscada por Abel Tiffauges até seu aniquilamento, é a prova derradeira e inequívoca de que os homens perderam a plenitude espiritual e emocional. Enquanto o mito adâmico dá conta de formular uma causa mítica para essa perda, atrelando-a à perda da plenitude corporal, historicamente o romance nos aponta, através da personagem de Tiffauges, que homem perdeu-se de si mesmo em algum momento e somente quando despontam os sinais mais evidentes de um cataclismo ele consegue se dar conta de que sua alma já não é mais una. $O$ mergulho que Tiffauges faz em seu próprio tempo o conduz até a metafísica religiosa e o alienamento; e apenas porque ele transita entre o onírico e o real, entre o mítico e o histórico, é que o romance consegue se sustentar.

Paradoxalmente, a escassez das referências específicas ao genocídio o mantém numa zona de desconforto silencioso; sem que ele seja amplamente descrito, representado, configurado, a presença dos mortos se faz constante, incômoda, assombrosa. O romance não se posiciona de maneira a oferecer um testemunho, nos moldes que fez Primo Levi e outros sobreviventes. No entanto, ele configura um testemunho nos termos em que Gagnebin propõe:

Não temos de pedir desculpas quando, por sorte, não somos os herdeiros diretos de um massacre; e se, ademais, não somos privados da palavra, mas, ao contrário, se podemos fazer do exercício da palavra um dos campos de nossa atividade, então nossa tarefa consistiria, talvez, muito mais em restabelecer o espaço 
simbólico onde se possa articular aquele que Hélène Piralian e Janine Altounian chama de "terceiro" - isto é, aquele que não faz parte do círculo infernal do torturador e do torturado, do assassino e do assassinado, aquilo que, "inscrevendo um possível alhures fora do par mortífero algoz-vítima, dá novamente um sentido humano ao mundo"27. No sonho de Primo Levi, deveria ser a função dos ouvintes, que, em vez disso e para desespero do sonhador, vão embora, não querem saber, não querem permitir que essa história, ofegante e sempre ameaçada por sua própria impossibilidade, os alcance, ameace também sua linguagem ainda tranquila; mas somente assim essa história poderia ser retomada e transmitida em palavras diferentes. Nesse sentido, uma ampliação do conceito de testemunha se faz necessária; testemunha não seria somente aquele que viu com seus próprios olhos, o histor de Heródoto, a testemunha direta. Testemunha também seria aquele que não vai embora, que consegue ouvir a narração insuportável do outro e que aceita que suas palavras levem adiante, como num revezamento, a história do outro; não por culpabilidade ou compaixão, mas porque somente a transmissão simbólica, assumida apesar e por causa do sofrimento indizível, somente essa retomada reflexiva do passado pode nos ajudar a não repeti-loinfinitamente, mas ousa esboçar ema outra história, a inventar o presente. (GAGNEBIN, 2007, p. 56-7)

Nesse sentido, é muito significativa a passagem - extremamente concisa - em que Abel encontra um cadáver "d'un être sans sexe et sans âge, impossible à identifier, sinon par un numéro tatoué sur le poignet gauche, et par un $\mathrm{J}$ jaune se détachant sur une étoile de David rougeâtre cousue au côté gauche. II remonta à cheval..." (TOURNIER, 1970, p. 470). Esse corpo morto, anônimo e portador de todos os indícios da perseguição e do extermínio, diante do qual Tiffauges não reage, é absoluto. Sua mera presença na trama marca esse sofrimento silencioso que é acolhido, pauta que o romance não perde de vista, por um instante sequer, "a história ofegante e ameaçada por sua própria impossibilidade". Entendemos que essa breve alusão ao corpo do prisioneiro é parte da homenagem que se presta aos mortos, é uma reverência silenciosa àqueles que não puderam passar adiante sua história, seu testemunho. Logo em seguida a esta "descoberta", Abel se depara com um menino sozinho, inerte e frágil:

\footnotetext{
${ }^{27}$ Apud. Hélène Piralian, "Écriture(s) du génocidaire", in Catherine Coquio (org.), Parler des camps, penser les génocides, Paris, Albin Michel, 1999, p. 541.
} 
II respirait, il vivait encore. Tiffauges le secoua doucement, voulut en tirer des réponses. Vainement. II était plongé dans une torpeur qui paraissait proche de la mort. Lorsque Tiffauges le souleva dans ses bras, il eut le cœur serré de le trouver si incroyablement léger, comme s'il n'y avait rien dans le ballot de tissus grossiers d'où sortait sa tête. (TOURNIER, 1970, p. 471)

Esse menino é Éphraïm, cuja vida Tiffauges salvará no fim do romance sacrificando a si mesmo, ele é a criança que cumprirá a profecia e o destino de Abel mimetizando a cena de São Cristóvão - assim como nessa passagem eles, juntos, reproduzem a cena do Rei carregando em seu cavalo um menino desfalecido. Como vimos ${ }^{28}$, Éphraïm trará a Abel o relato de suas experiências no campo de concentração, que é o único lugar de que ele se lembra em sua vida, contará em detalhes sobre a sobrevivência e também a morte; sua palavra constitui, portanto, um esboço de testemunho feito na trama, dentro da estrutura narrativa polifônica e multireferenciada, a história do menino opõe-se à dos militares, é a história de quem sobreviveu, na outra ponta da máquina nazista, de quem saiu dos campos e pôde passar adiante sua experiência. Ora, se Éphraïm é a projeção da testemunha em primeiro grau, Abel é justamente o ouvinte, o "terceiro" que não herda o ônus do massacre e para quem o relato dos campos soa desesperador. Contudo, Abel não recusa a história que lhe é transmitida, ele fica ao lado do menino, ouve e reescreve o que ouviu, ou seja, Abel completa o ciclo que Gagnebin descreve em seu texto, ele cumpre - não por culpabilidade ou compaixão - o que the cabe como testemunha.

Em última análise, o romance simbolicamente executa esse gesto necessário de transmissão da experiência do outro, ele mesmo recupera, revisa e elabora

\footnotetext{
${ }^{28}$ Ver "A necessidade e a estetização da Barbárie" p. 100
} 
mitologicamente o passado e, ironicamente, manipulando todo um sistema mítico de reiterações e repetições, propõe um apocalipse histórico que impede a repetição do horror. 


\section{REFERÊNCIAS}

\section{Do autor}

TOURNIER, M. Le roi des aulnes. Paris: Gallimard. 1970.

. O Rei dos Álamos. Trad. Joana Morais Varela. Lisboa: Publicações Dom Quixote, 1986.

Le vent paraclet. Paris: Gallimard, 1977.

. Des clefs et des serrures. Paris: Hachette, 1979.

. Le vol du vampire: notes de lecture. Paris: Gallimard, 1983.

. Le Coq de bruyère. Paris: Gallimard, 1991.

. Le miroir des idées: Traité. Mesnil-sur-l'Estré: Mercure de France, 1994.

. Préface. In: JAQUET, J. Euphorie. Paris: Buchet/Chastel, 2003.

\section{Teoria e crítica}

AGAMBEM, G. O que resta de Auschwitz: o arquivo e a testemunha (Homo Sacer III). Tradução Selvino J. Assmann. São Paulo: Boitempo, 2008.

BENJAMIN, W. Magia e Técnica, arte e política: ensaios sobre literatura e história da cultura. Tradução de Sérgio Paulo Rouanet. 7ª ed. São Paulo: Brasiliense, 1994. (Obras escolhidas, v. 1).

BOULOUMIÉ, A. Michel Tournier: Le roman mythologique suivi de questions à Michel Tournier. [Paris]: Librairie José Corti, 1988. 
BOULOUMIÉ, A. (Dir.); GANDILLAC, M. (Dir.). Images et signes de Michel Tournier: Actes du colloque du Centre Culturel International de Cerisy-la-Salle. [Paris]: Gallimard, 1990.

BRUNEL, P. (Org.). Dicionário de mitos literários. Tradução de Carlos Sussekind et al. $4^{\underline{a}}$ ed. Rio de Janeiro: José Olympio, 2005.

CALVINO, I. A combinatória e o mito na arte narrativa. In: . Atualidades do Mito. Tradução de Carlos Arthur R. do Nascimento. São Paulo: Duas Cidades, 1977.

CARROLL, N. A natureza do horror. In: A filosofia do horror ou paradoxos do coração. Tradução de Roberto Leal Ferreira. [ ]: Papirus, [ ].

CORNELSEN, E. L. Literatura sob o jugo totalitário: considerações sobre a obra "Las Casas vor Karl V. «, de Reinhold Schneider. In: . Revista Letras, n. 22. Universidade Federal de Santa Maria.

ELIADE, M. O Sagrado e o Profano. Tradução de Rogério Fernandes. São Paulo: Martins Fontes, 1992. 2002. Mito e realidade. Tradução de Pola Civelli. $6^{\underline{a}}$ ed. São Paulo: Perspectiva, FREUD, S. O estranho. In: Obras completas. Rio de Janeiro: Delta, 1959.

GAGNEBIN, J. M. História e narração em Walter Benjamin. $2^{\underline{a}}$ reimpr. da $2^{a}$ ed. de 1999. São Paulo: Perspectiva, 2007.

. Lembrar escrever esquecer. São Paulo: Ed. 34, 2006.

GENETTE, G. Figures III. Paris: Seuil, 1972.

GIRARDET, R. Mitos e mitologias políticas. Tradução de Maria Lúcia Machado. São Paulo: Cia. das Letras, 1987.

HOBSBAWN, E. A era da catástrofe. In: Era dos extremos: o breve século XX: 1914 - 1991. Tradução de Marcos Santarrita. São Paulo: Companhia das Letras, 1995. 
IGLÉSIAS, F. A narrativa em questão. In: RIEDEL, D. C. (Org.). Narrativa, ficção e história. Rio de Janeiro: Imago, 1988.

KOSTER, S. Michel Tournier, ou le choix du roman. [Paris]: Zulma, 2005.

LACOUE-LABARTHE, P.; NANCY, J. O mito nazista. Tradução de Márcio Seligmann-Silva. São Paulo: Iluminuras, 2002. (Coleção Testemunhos)

LUKÁCS, G. A teoria do romance. Tradução de José Mariani de Macedo. $3^{\text {a }}$ reimpr. da $1^{\underline{a}}$ ed. São Paulo: Duas Cidades/Ed. 34, 2000.

NUNES, B. Narrativa histórica e narrativa ficcional In: RIEDEL, D. C. (Org.). Narrativa, ficção e história. Rio de Janeiro: Imago, 1988.

RAMNOUX, C. Mitológica do tempo presente. In: Atualidades do Mito. São Paulo: Duas Cidades, 1977.

RICCEUR, P. A memória, a história, o esquecimento. Tradução de Alain François et al. Campinas: Editora da UNICAMP, 2007.

. Le conflit des interprétations. Paris: Seuil, 1969.

O Mal: um desafio à filosofia e à teologia. Tradução de Maria da Piedade Eça de Almeida. Campinas, SP: Papirus, 1988.

Philosophie de la volonté. Paris: Aubier-Montaigne, 1960. Tome 2:

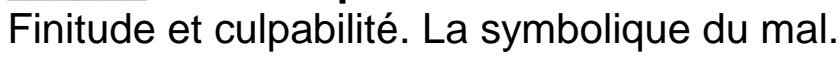

. Temps et récit. L'intrigue et le récit historique. Tome 1. Paris: Seuil, 1983.

ROSENFELD, A. À procura do mito perdido: notas sobre a crise do romance psicológico In: . Letras e Leituras. São Paulo: Perspectiva, 1994.

RUTHVEN, K. K. O mito. Tradução de Esther E. H. de BeerMann. São Paulo: Perspectiva, 1997. (Coleção Debates) 
SCHWARZ, R. 81/2 de Fellini: O menino perdido e a indústria. In: A Sereia e o Desconfiado: ensaios críticos. $2^{2}$ ed. Rio de Janeiro: Paz e Terra, 1981. (Coleção Literatura e Teoria Literária, v. 37)

SEVCENKO, N. No princípio era o ritmo: as raízes xamãnicas da narrativa. In: RIEDEL, D. C. (Org.). Narrativa, ficção e história. Rio de Janeiro: Imago, 1988.

SHIRER, W. L. Ascensão e queda do Terceiro Reich. Tradução de Pedro Pomar. 1ํㅡㄹ reimpr. Rio de Janeiro: Agir, 2008. v. 1: Triunfo e consolidação (1933-1939).

Tradução de Pedro Pomar e Leônidas Gontijo de Carvalho. $1^{\text {a }}$ reimpr. Rio de Janeiro: Agir, 2008. v. 2: O começo do fim (1939-1945).

VERNANT, J. Aspectos míticos da história e do tempo. In: Mito e pensamento entre os Gregos: Estudos de psicologia histórica. Tradução de Haiganuch Sarian. Revisão técnica de Erika Pereira Nunes. Rio de Janeiro: Paz e Terra, 1990.

. Entre Mito e Política. Tradução de Cristina Murachco. 2aㅡ ed. São Paulo: Editora da Universidade de São Paulo, 2002.

WATT, I. Mitos do individualismo moderno. Tradução de Mario Pontes. Rio de Janeiro: Jorge Zahar, 1997. 